\title{
Germany: 2010 Article IV Consultation-Staff Report; Public Information Notice on the Executive Board Discussion; and Statement by the Executive Director for Germany
}

Under Article IV of the IMF's Articles of Agreement, the IMF holds bilateral discussions with members, usually every year. In the context of the 2010 Article IV consultation with Germany, the following documents have been released and are included in this package:

- $\quad$ The staff report for the 2010 Article IV consultation, prepared by a staff team of the IMF, following discussions that ended on February 8, 2010, with the officials of Germany on economic developments and policies. Based on information available at the time of these discussions, the staff report was completed on March 10, 2010. The views expressed in the staff report are those of the staff team and do not necessarily reflect the views of the Executive Board of the IMF.

- $\quad$ A Public Information Notice (PIN) summarizing the views of the Executive Board as expressed during its March 29, 2010 discussion of the staff report that concluded the Article IV consultation.

- A statement by the Executive Director for Germany.

The policy of publication of staff reports and other documents allows for the deletion of market-sensitive information.

Copies of this report are available to the public from

International Monetary Fund $\bullet$ Publication Services

$70019^{\text {th }}$ Street, N.W. $\bullet$ Washington, D.C. 20431

Telephone: (202) 623-7430 • Telefax: (202) 623-7201

E-mail: publications@imf.org Internet: http://www.imf.org

\section{International Monetary Fund Washington, D.C.}




\section{INTERNATIONAL MONETARY FUND}

\section{GERMANY}

\section{Staff Report for the 2010 Article IV Consultation}

Prepared by the Staff Representatives for the 2010 Consultation with Germany

Approved by Marek Belka and Tamim Bayoumi

March 10, 2010

\section{Executive Summary}

The German economy is regaining the ground lost in the crisis. Policy support, restocking, and an uptick in global demand have lifted the economy from the recession. The recovery is likely to be moderate, however: export growth is projected to be slower than before the crisis, continuing banking fragilities pressure credit supply, and increasing unemployment will keep consumers cautious. And it will take time to repair the damage to potential growth after dislocations from the crisis. Following a drop of about 5 percent in 2009, staff now projects GDP to grow by 1.2 percent in 2010 and 1.7 percent in 2011 . The recovery remains fragile because of mostly downward risks for export and credit growth.

This leaves Germany's policymakers with the delicate task of managing ongoing risks and exiting extraordinary support measures. The authorities' policy measures-providing significant fiscal stimulus and letting automatic stabilizers work, mitigating systemic financial stress and supporting credit, and using labor market policies to smooth employment- were crucial to the resumption of growth. A key policy challenge now is to prepare the exit from these crisis policies:

- Fiscal consolidation. The 2010 budget continues to provide stimulus during a still fragile recovery. With the recovery expected to firm up by 2011, the government is committed to fiscal consolidation, not least to anchor fiscal policy in the euro area. But strong measures will be needed to meet the SGP and national deficit rules in the medium term, and tensions in the fiscal plans for 2011, which include sizable permanent tax cuts, need to be resolved.

- Continued financial sector restructuring and reform. While the health of the banking sector has improved in general, the Landesbanken sector remains structurally unprofitable. The authorities broadly agreed with staff's call for major consolidation of the Landesbanken while stressing the voluntary nature of the process. The authorities also agreed on the need to put in place an effective bank resolution regime in line with EU efforts but, unlike the staff, they did not see reforming the fragmented deposit insurance scheme as a priority. The staff supported the government's plans to make the Bundesbank the sole prudential bank supervisor as this should enhance accountability and speed up enforcement.

- Structural reform. The authorities plan to withdraw gradually short-term crisis policies in the labor market so that these do not become impediments to long-run growth. The authorities also agree that structural policies can make the economy more flexible and strengthen domestic sources of growth. This would allow Germany to adjust to slower foreign demand and could help to reduce current account imbalances within the euro area and globally. 


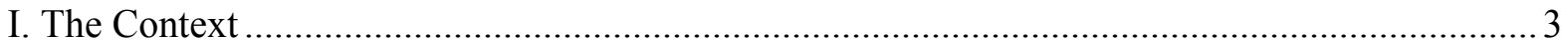

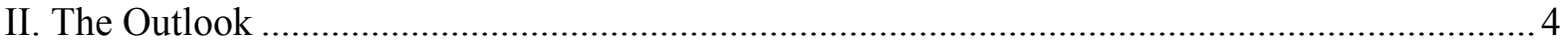

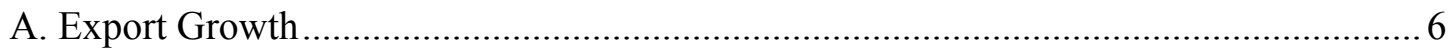

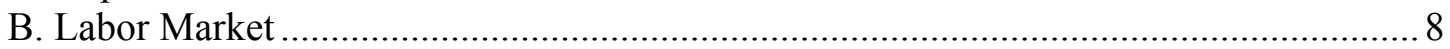

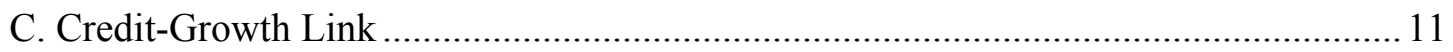

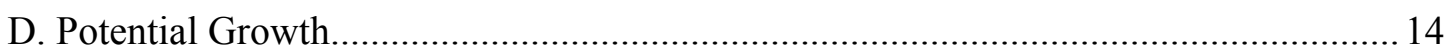

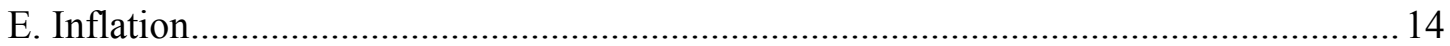

III. Fiscal Policy: From Stimulus to Consolidation .......................................................16

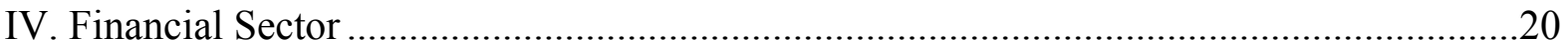

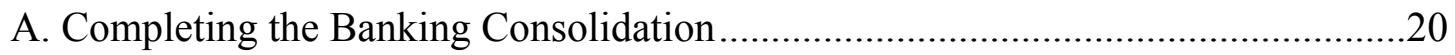

B. The Financial Stability Framework ...............................................................24

V. Adjusting Structural Policies ..................................................................................26

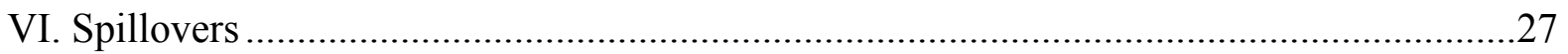

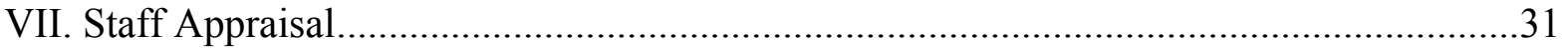

Tables

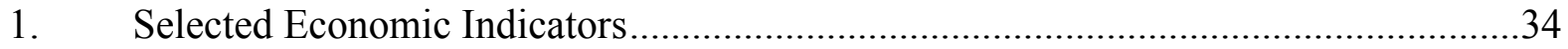

2. Foreign Claims of Banks on Individual Countries, December 31, 2009 ...................36

3. The Core Set of Financial Soundness Indicators for Banks, 1999-2008 ....................37

4. Encouraged and Other Financial Soundness Indicators, 1999-2008 ..........................38

5. Medium-Term Balance of Payments, 2007-15 ...................................................39

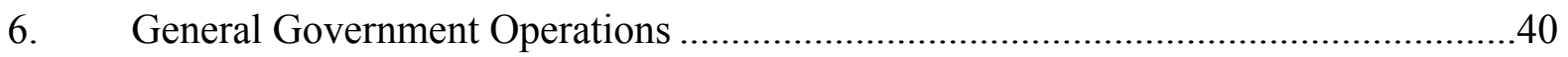

\section{Boxes}

1. Main Policy Measures 2009 ....................................................................................5

2. Why has Germany's Employment Held Up so Well? ...............................................10

3. Bank Balance Sheets and the Recovery .................................................................. 13

4. The Effects of the Crisis on Potential Growth ........................................................15

5. Car-Scrapping Program ..................................................................................... 17

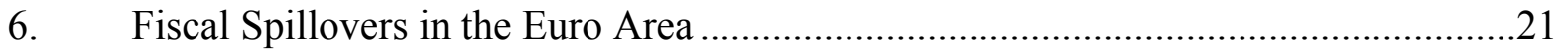

7. The German Financial Market Stabilization Fund ..................................................22

8. Foreign Exposure of German Banks.....................................................................29 


\section{The CONTEXT ${ }^{1}$}

1. Strong policy support helped Germany emerge from the deep recession. Germany was hit exceptionally hard by the crisis. But financial sector measures mitigated systemic stress and supported credit (Box 1). Automatic stabilizers and significant fiscal stimulus contained the downswing and supported the recovery. And the surprisingly strong German labor market reflected flexibility gains from past labor market reforms, together with the expansion of the short-term subsidies (Kurzarbeit) program.

2. With a moderate, but fragile, recovery underway, policy demands are changing. While crisis policies need to continue in some areas, there is a need for exit in others.

- $\quad$ Fiscal policy: The recovery continues to rely on fiscal support for one more year, but consolidation is in order once private demand has become self sustaining. This sits uncomfortably with plans for tax cuts in 2011.

- $\quad$ Dealing with the crisis aftershocks: With liquidity conditions set to tighten and credit playing a crucial role for the recovery, time is running out for solving the remaining banking sector problems, in particular in the Landesbanken sector.

- $\quad$ Financial stability framework: Ensuring and improving financial stability remains important, and the authorities are proceeding - if gradually. A plan to introduce a banking resolution regime is being discussed, and there is a commitment to increase the Bundesbank's role in prudential supervision. However, little progress is being made in addressing the still fragmented deposit insurance system. An FSAP Update is planned for late 2010 .

- $\quad$ Allowing adjustment: Short-term crisis policies in the labor market and state aid to smooth employment could become impediments to long-run growth if continued indefinitely. The adjustment to slower foreign demand would benefit from service sector and labor market reforms to strengthen domestic sources of growth.

\section{Successfully tackling the crisis fallout will also help sustain the upswing in} Europe and elsewhere, with positive feedback effects for the German economy. Europe's tightly integrated trade and financial markets create substantial spillovers, but they also open the door to positive feedback effects from fiscal consolidation and solving the remaining banking sector problems. These effects are particularly strong for a large and open economy such as Germany. Strengthening domestic sources of growth would contribute to the

\footnotetext{
${ }^{1}$ The staff team comprised Messrs. Kähkönen (head), Berger, Schindler, Clausen (all EUR); Seelig (MCM), Tressel (RES), and Ms. Luedersen (LEG). Mr. Mody (EUR) supported the mission from Washington. Mr. von Stenglin (AED) attended the key meetings. The mission took place during January 27-February 8, 2010.
} 
reduction of both euro area and global current account imbalances and, thereby, reduce the risk of rapid or excessive exchange rate movements which tend to hurt trade.

\section{The OUTLOOK}

\section{The global forces that drove Germany's economy into the crisis have pulled} growth back into positive territory. The uptick started in the second quarter of 2009 , led by exports and aided by policy support and restocking of inventories. Reflecting restocking and the high import content of German exports, import growth has picked up, too, reducing the contribution of net exports to growth. Private consumption, which held up well during the recession against a background of surprisingly stable employment, oscillated first upward and then downward in reaction to fiscal incentives, especially the car scrapping program.
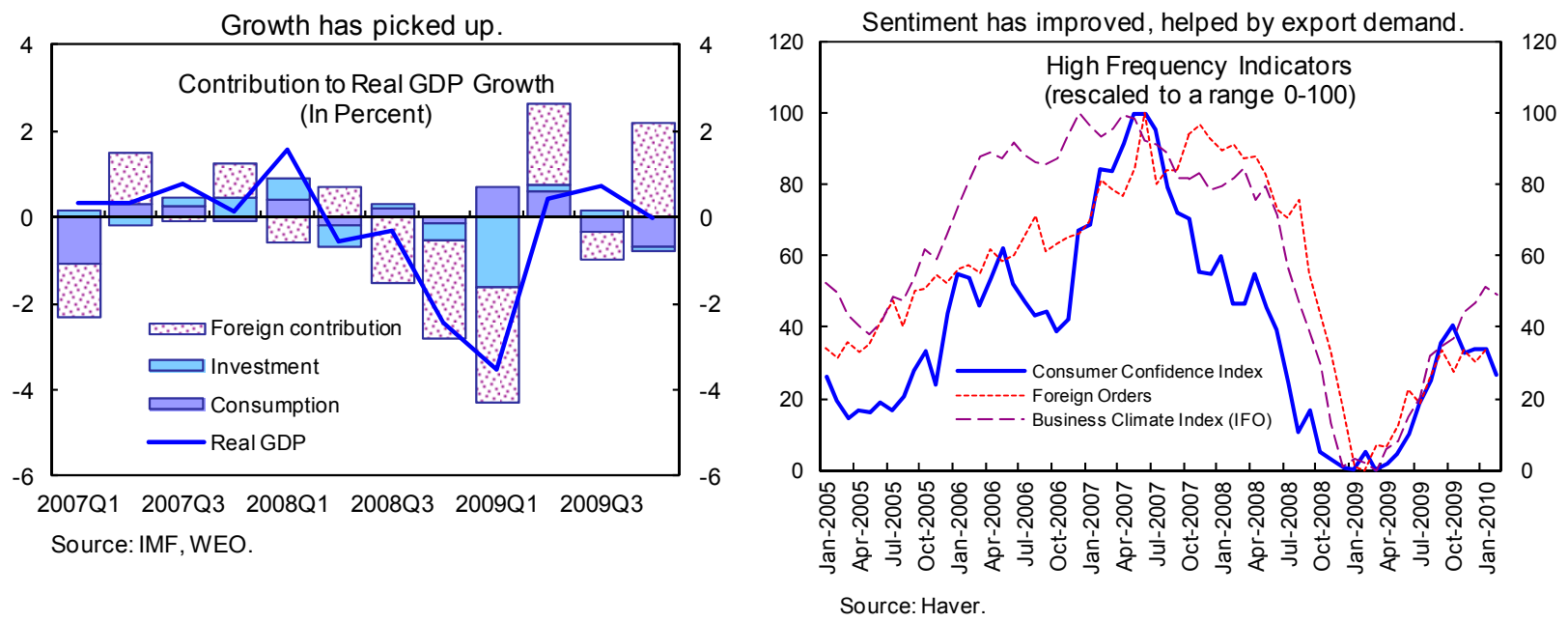

5. Staff and authorities see the recovery as moderate. A number of factors are at play. With U.S. consumers likely to show restraint for some time and global policy support eventually fading, the scope for export growth beyond the current global inventory bounce is limited. Continuing banking problems will put pressure on credit supply and possibly domestic demand as the recovery matures. Unemployment is projected to increase as firms adjust to the reality of lower post-crisis growth and government subsidies for short-time work lose their lure, which will further limit consumption. And it will take time to repair the damage to potential growth done by the crisis. Following an estimated drop of about 5 percent in 2009, staff now projects GDP to grow by 1.2 percent in 2010 and 1.7 in 2011. While the government's projections are a shade more optimistic than staff's, there is broad agreement that the uncertainty around the recovery path comes with a downward bias, owing to risks to exports and the financial sector (such as a credit crunch, or spillovers from emerging and Southern European markets). Such setbacks could have self-enforcing effects, with additional pressures on unemployment. 


\section{Box 1. Main Policy Measures 2009}

During 2009, the German authorities took action in a broad range of policy areas, including fiscal, financial, and the labor market.

In the fiscal area, the authorities combined significant short-term stimulus with a strengthening of the medium-term framework:

- Reacting to the depth of the downturn, the authorities in February enacted a second stimulus package (Konjunkturpaket II) with a fiscal cost of about 2 percent of GDP distributed across 2009 and 2010. In addition, the authorities extended the cash-for-clunkers scheme, which had a notable impact on car sales and private consumption (Box 5). The year also saw reductions in contribution rates to unemployment and health insurance in January and July, respectively. In December, the new government followed up with the Wachstumsbeschleunigungsgesetz, with tax breaks and transfers of about $1 / 4$ percent of GDP.

- At the same time, the new fiscal rule ("Schuldenbremse"), anchored in the constitution in June, now limits the structural deficit of the federal government to 0.35 percent of GDP starting in 2016 - to be reached in roughly equal consolidation steps starting in 2011 - and that of the Länder to balance by 2020, setting clear limits to debt accumulation in the medium term.

In the labor market, key actions during the first half of 2009 included measures that enhanced the generosity of the very effective short-time (Kurzarbeit) subsidy scheme, including increased subsidy levels and longer durations of eligibility (Box 2).

A series of financial sector measures helped stabilizing the banking sector:

- The Sonderfonds Finanzmarktstabilisierung (SoFFin) established in 2008 (see Box 7) helped stabilizing the banking sector, including through recapitalizations of Commerzbank and Hypo Real Estate (HRE) (see separate text figure).

- The Finanzmarktstabilisierungsergänzungsgesetz in April introduced a temporary option for public takeover of banks, allowing the October nationalization of HRE.

- The Gesetz zur Fortentwicklung der Finanzmarktstabilisierung (Bad-Bank-Act) passed in July allows banks to transfer impaired assets to specially created legal vehicles in return for SoFFinguaranteed government bonds and a fee. The scheme includes additional options supporting bank consolidation, including through removing entire business areas from the core bank. 

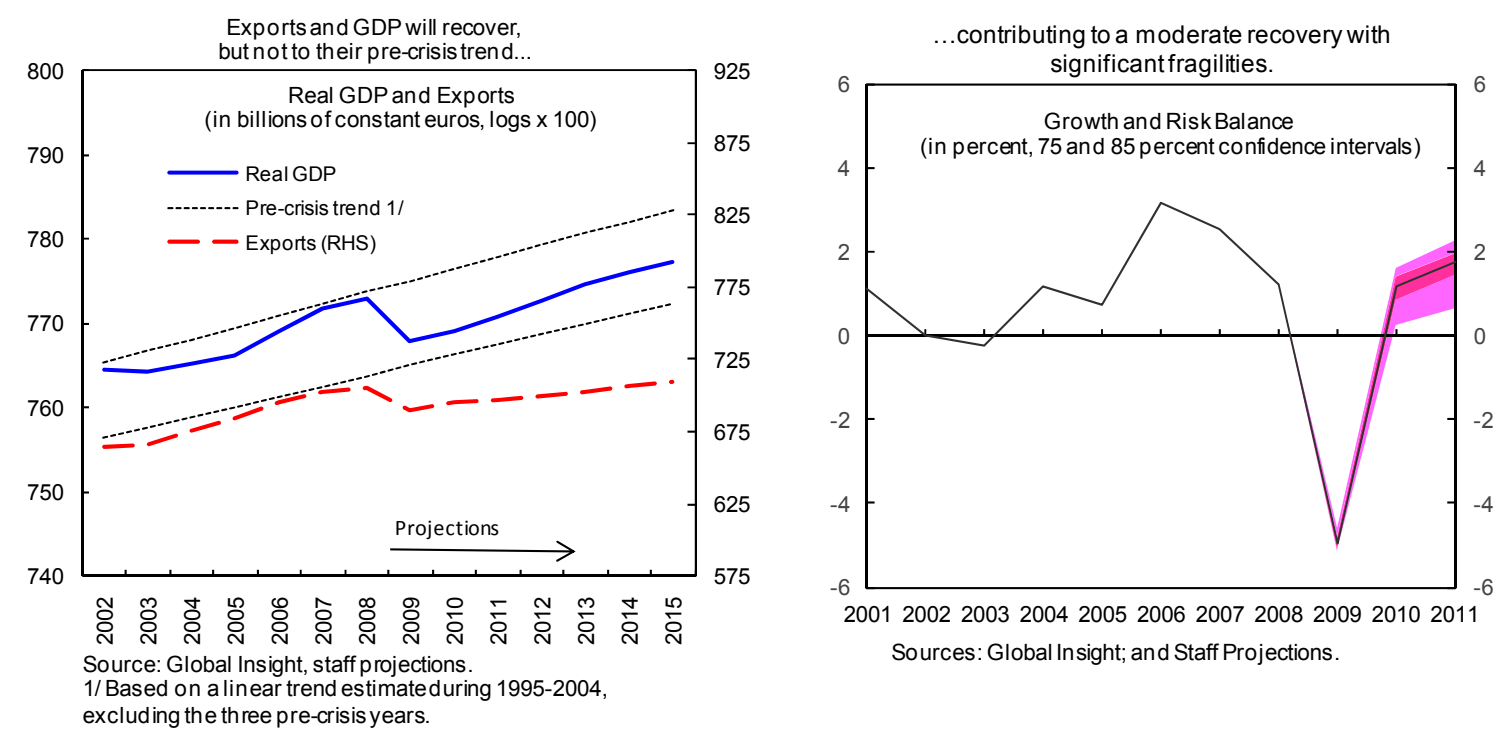

\section{A. Export Growth}

\section{Germany is tied closely to the ups} and downs of the global economy. German recoveries traditionally start with a pick-up in exports, reflecting the importance of the foreign-demand-oriented manufacturing sector in value added. The draw of demand from EU neighbors - including from the euro area-is particularly important, given these countries' large share in German trade. But non-EU export growth picked up considerably in the run-up to the crisis, as German manufacturers profited from strong U.S. and Asian demand.

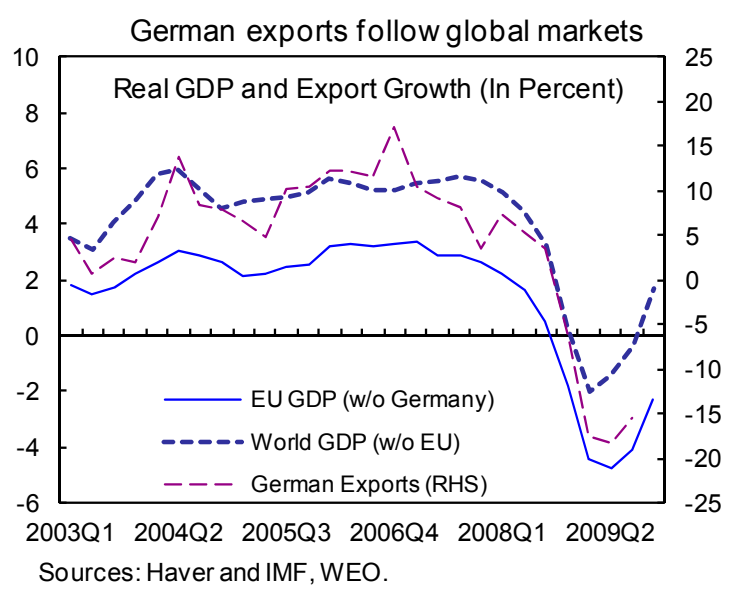

China exports grow strongly, but from low levels.

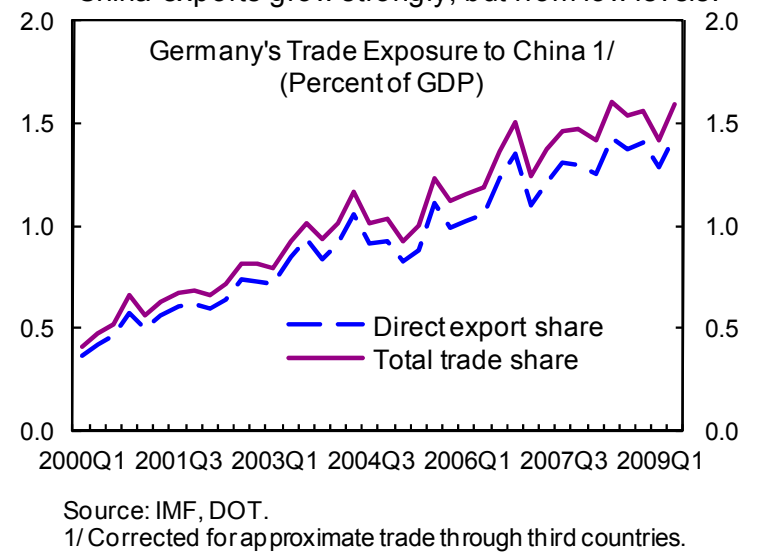

\section{Export growth is likely to be lower}

following the crisis. The recovery in Europe is projected to be slow, with particular weaknesses in the South. U.S. consumers are likely to show some restraint relative to their pre-crisis spending, which will moderate global demand, especially once the effects of global fiscal stimulus and restocking subside. And while Chinese growth is expected to remain high, its overall pull remains relatively limited due to the still small share in German exports. 


\section{Another moderating factor could be the dent the crisis put into German}

competiveness. While the euro has been depreciating more recently, it had gained in strength against the U.S. dollar and major currencies in the course of the global crisis. In addition, wage growth picked up markedly just prior to the crisis in early 2008, ending a period of wage discipline. These developments, together with an increase in unit labor costs caused by labor hoarding, have put upward pressure on the ULC-based real exchange rate.

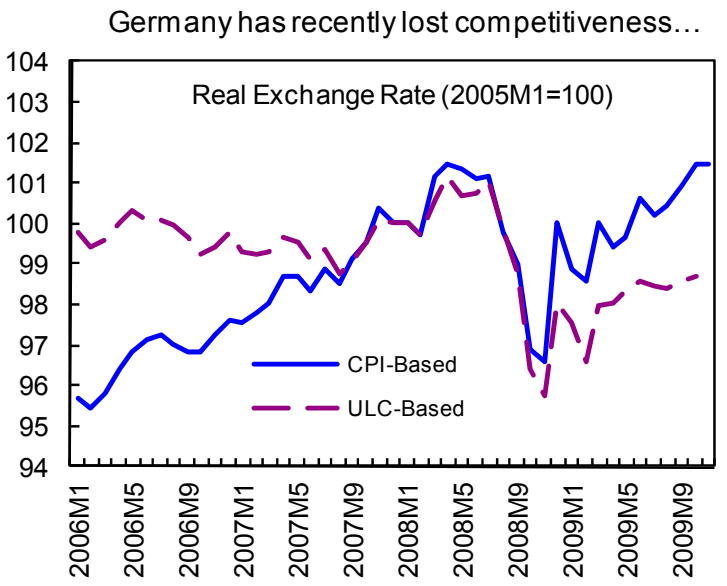

Source: IMF, IFS.

Note: A rise in the real exchange rate corresponds to an ap preciation.

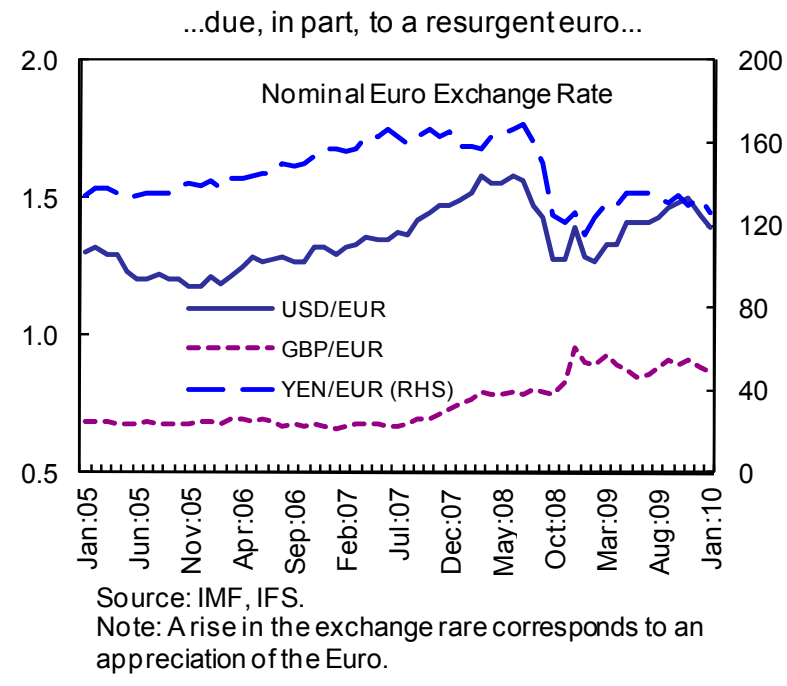

9. However, CGER estimates suggest that the deterioration in competitiveness has been small, with Germany retaining a small competitiveness advantage. According to

Germany: Competitiveness Assessment 1/

\begin{tabular}{lrrrr}
\hline & $\begin{array}{r}\text { Macro- } \\
\text { Balances }\end{array}$ & $\begin{array}{r}\text { External } \\
\text { Sustainability }\end{array}$ & $\begin{array}{r}\text { Eq. Real. } \\
\text { Exch. Rate }\end{array}$ & Average \\
\hline Fall 2008 & -4 & -15 & 2 & -5.7 \\
Fall 2009 & 1 & -14 & 4 & -3.0 \\
\hline
\end{tabular}
the External Sustainability approach, the current account surplus substantially exceeds what is required to sustain net foreign asset levels, implying a strong competitive advantage. But the

Source: IMF staff estimates.

1/ A negative number indicates a competitiveness advantage.

enduring tradition of German current account surpluses suggests that other factors not captured by the approach (including perhaps a preference for the accumulation of foreign assets) play a role, which could overstate competitiveness. The Equilibrium Real Exchange Rate concept - which compares the actual and a computed equilibrium real exchange rates - indicates a small competitive disadvantage, but could also be misleading because of it relies on

Real wages increased before and ULC during the crisis, but both have started to adjust.

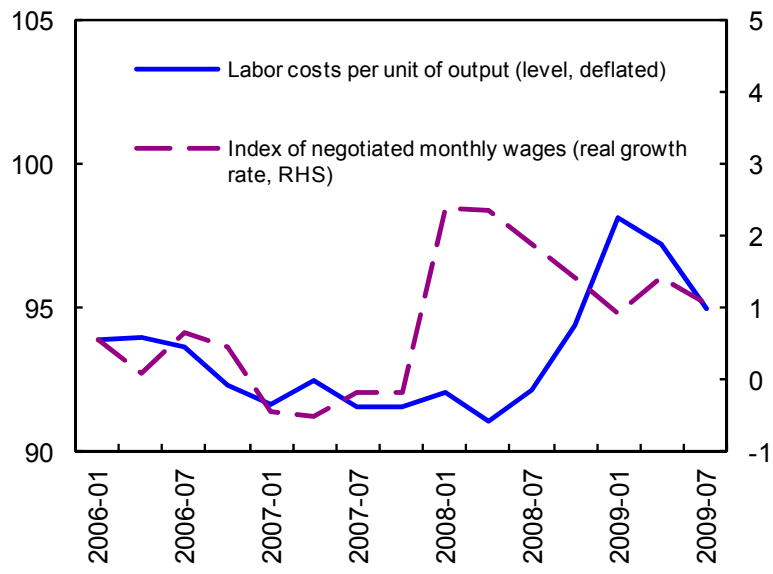

Source: Bundesbank. 
CPI-based real exchange rates and ignores real wage developments. The Macrobalances approach may be best suited for Germany. It reflects the difference between the actual savings-investment balance and a computed equilibrium (based, among other things, on estimated saving preferences and demographic factors), and puts Germany at a broadly neutral level. Taking a simple average of these measures - as is customary - suggests that Germany retains a small competitive advantage, consistent with the authorities' analysis. In addition, wage growth has started to moderate since mid-2008 and labor hoarding is expected to unwind, which will lift productivity.

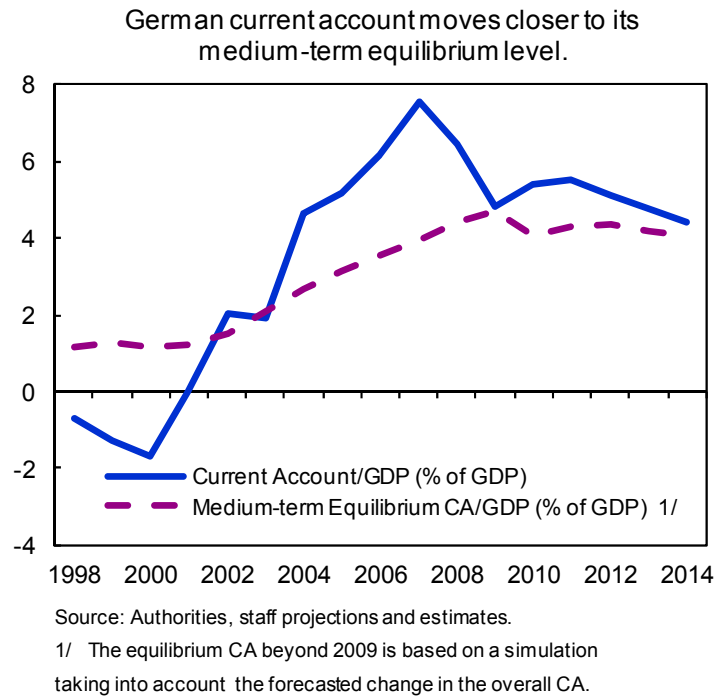

downward risks for export growth were to materialize: demand from Asia could fall short of expectations and a sharp depreciation of the U.S. dollar in tandem with Asian currencies could add additional downward momentum.

\section{B. Labor Market}

\section{Employment held up} extraordinarily well during the recession. The drop in GDP was among the highest among EU countries and much more pronounced than in past downswings. Yet, employment was astoundingly robust. Unemployment increased only moderately from 7.2 percent in the third quarter of 2008 to 7.5 percent in the fourth quarter of 2009 , sparking speculation about the reasons

\section{As for the current account position,} the outlook is for a moderation of the surpluses. Under the baseline scenario, the current account surplus will fall significantly from its pre-crisis heights, reflecting lower export growth. After reaching 7 $1 / 2$ percent of GDP in 2007, it is projected to reach $5 \frac{1}{2}$ percent of GDP in 2010. This would bring the current account surplus broadly in line with the equilibrium level suggested by the Macrobalances approach. However, the current account surplus could be even lower if
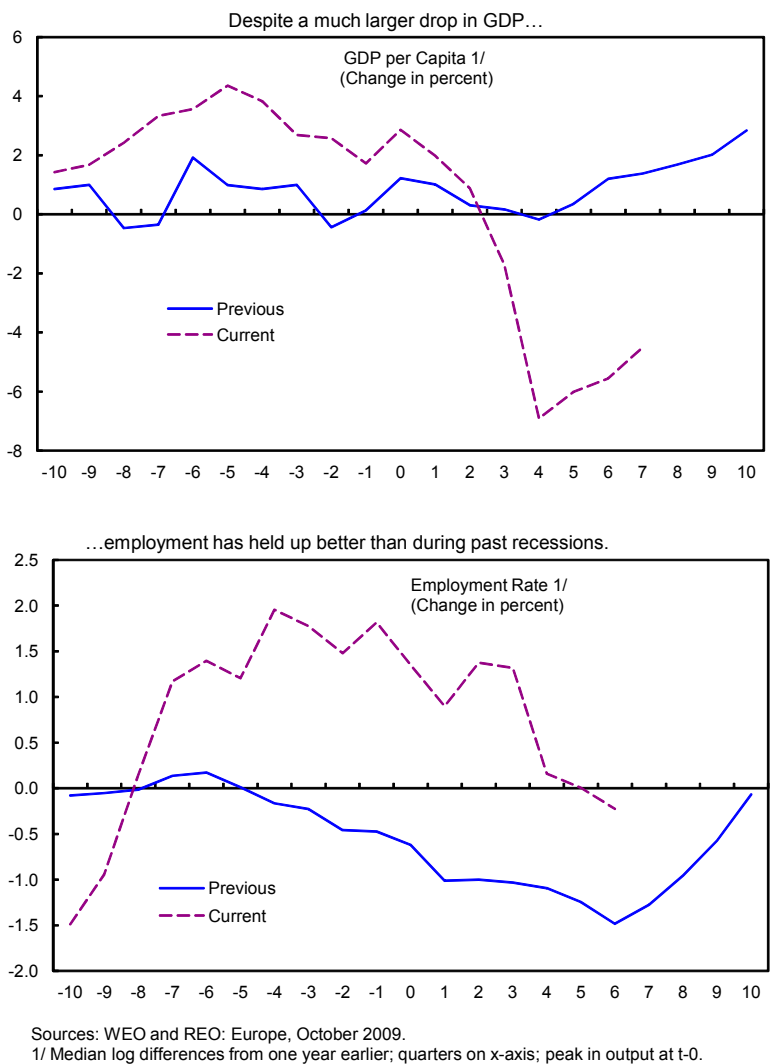
Actual and Expected Unemployment $1 /$ (percentage points)

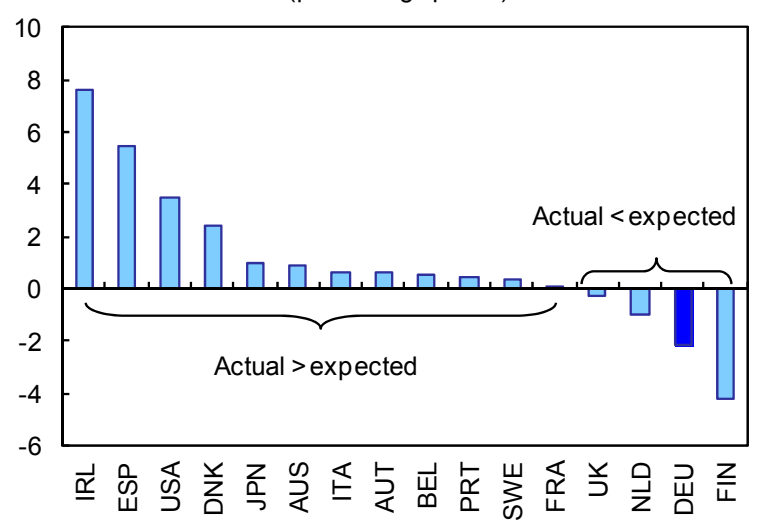

Sources: Global In sight; and staff estimates.

1/Based on an empirical mo del relating real GDP

growth to changes in unemployment during 1991Q1:2008Q1. behind the German "labor market miracle." A closer look reveals a combination of factors at work (Box 2). Statistical changes played a role, but more important were increased firmlevel flexibility to smooth working hours over the cycle (owing to less restrictive collective bargaining agreements), and a stronger underlying employment trend supported by the labor market reforms of recent years (Hartz IV). The single most important crisis policy influencing employment has been the government program subsidizing short-time work (Kurzarbeit). While Kurzarbeit has long been a staple of German labor market policies, the scheme was made significantly more generous during the crisis. At its peak, over 1.5 million employees (or 3.5 percent of the labor force) worked under the scheme, mostly in the hard-hit manufacturing sector.

\section{But both authorities and staff see unemployment increasing as firms adjust to}

lower post-crisis growth. While the Kurzarbeit subsidies have helped firms to hold on to their workforce, they also increased hourly labor costs. As a consequence, firms will eventually need to adjust employment - in particular, if they have reason to expect that demand will not return to pre-crisis levels soon. Thus, even with the Kurzarbeit scheme in place, a moderate recovery will see unemployment increase. Staff expects unemployment to increase during 2010, reaching a peak of 9.5 percent by the end of the year. The authorities have a broadly similar view of the labor market outlook but see unemployment increasing more gradually. The increase will be fueled by layoffs, including by employees exiting from the Kurzarbeit scheme into unemployment.

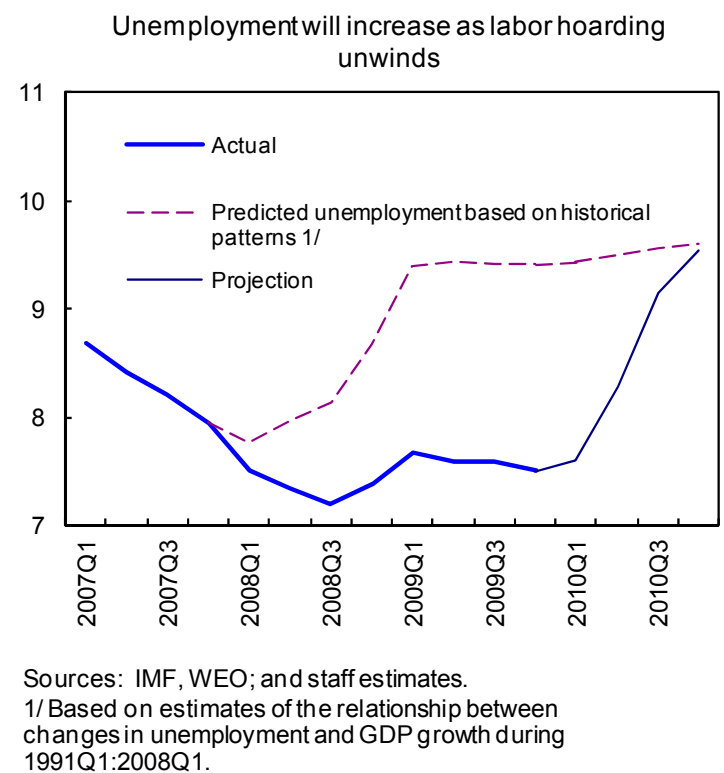

\section{The deterioration of the labor market will weigh on consumption and the}

recovery. The increase in unemployment, and the increased employment uncertainty created 


\section{Box 2. Why has Germany's Employment Held Up So Well?}

Despite the large decline in output, employment has fallen by less than $1 / 2$ percent since its peak, a remarkably mild response both historically and internationally. Extrapolating from the past relationship of GDP growth and unemployment changes, unemployment would have reached about 9.5 percent - about 2 percentage points higher than observed. (The gap could have been three times as high if unemployment had reacted as strongly as in the United States).

The moderate unemployment response reflects in part an improved underlying employment trend supported by the labor market reforms (Hartz IV), and, importantly, increased firm-level flexibility to smooth work hours over the cycle owing to less restrictive collective bargaining

Labor market adjustment has been predominantly on the in tensive margin...

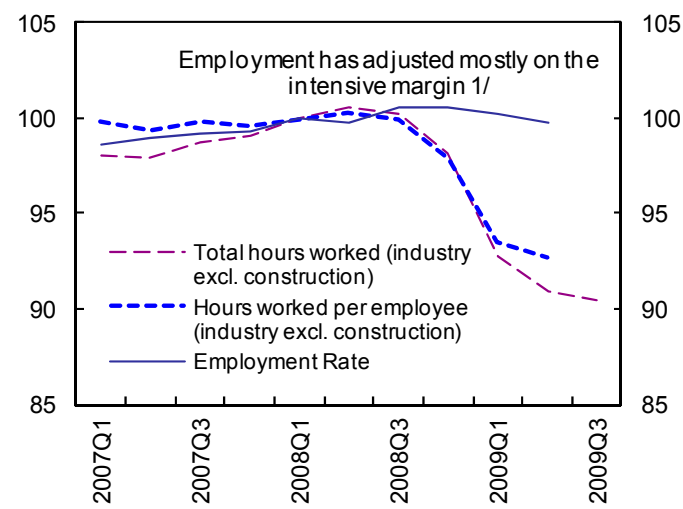

Sources: Haver and OECD. $1 /$ All series are normalized to $2008 Q 1=100$.

Whether employment losses can be avoided also in the medium term depends on a number of factors. First, the flexibility offered by Arbeitszeitkonten has been largely exhausted, and given that firms face residual costs on short-time work, many may be forced to lay off workers if production levels remain low for too long. Second, structural shifts in the economy, which often accelerate during recessions, may eventually require employment adjustments. Lastly, hourly flexibility works both ways: firms may target lower employment levels in the future assuming that higher demand can temporarily be accommodated by increases in hours worked. This suggests that deterioration in labor market outcomes may yet occur. agreements. ${ }^{1 /}$ Indeed, much of the adjustment has taken place internally — and, thus, less visibly — through working hours reductions. Some of the hours reductions were due to work-sharing arrangements negotiated between firms and employees (often as part of bargaining agreements), especially the use of worktime accounts (Arbeitszeitkonten). They were also supported by short-time subsidies (Kurzarbeit), traditionally a feature of the German labor market, that were made substantially more generous in 2008/09. ${ }^{2 /}$ Take-up reached over 1.5 million workers at its peak, a full-time equivalent of nearly half a million positions, surpassed only by the levels during the postreunification years.

\footnotetext{
${ }^{1 /}$ Recent statistical changes have contributed to smaller measured unemployment, but even accounting for these changes, the overall picture of a historically mild response in unemployment remains.

2/ Short-time subsidies cover up to 67 percent of a worker's lost income. Recent changes included an extension of the maximum duration to 24 months and increased coverage of firms' social contributions.
} 


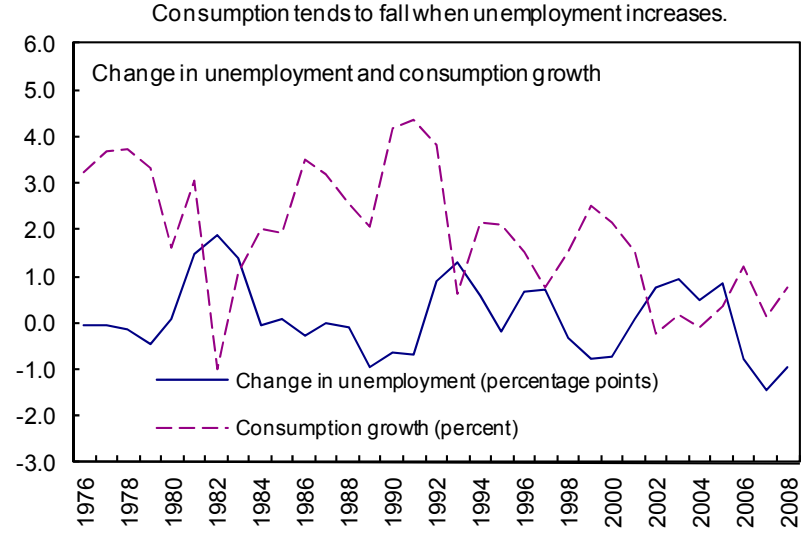

Source: IMF, WEO by it, will have a dampening effect on consumption, as households deal with income losses or spend more cautiously to prepare for the eventuality. ${ }^{2}$ This effect is exacerbated by low expected wage growth during 2010. While this moderates expected growth, the risks resulting from labor market developments to the forecast should be broadly balanced.

\section{Credit Growth}

\section{With both credit supply and demand weak, there is little clear evidence of a} credit crunch at the current juncture. While banks have deleveraged their balance sheets since the start of the crisis and bank lending surveys provide mixed signals, corporate credit has declined broadly in line with GDP, suggesting that demand factors have been at play, too. Empirical analysis by the authorities and staff confirms this view. ${ }^{3}$ Easing the pressure, large corporations have relied on the bond market to roll over existing debt, and there are indications that small and medium-sized firms (SMEs) benefited from access to smaller banks that have kept credit lines open. Still, public concern about reduced access to credit for SMEs exists. The 2009 stimulus package

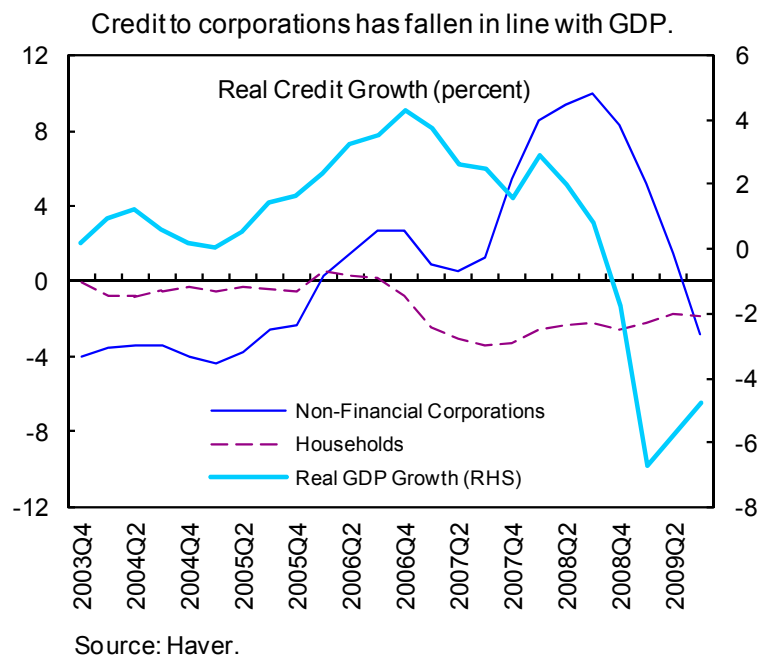
included a program to support SME credit supply by shifting credit risk to the Kreditanstalt für Wiederaufbau ( $K f W$, a federal public bank).

\section{With looming bank write-downs and pending regulatory demand for additional capital, the authorities share the staff's concern that credit supply could run short when}

\footnotetext{
${ }^{2}$ Mody and Ohnsorge, “After the Crisis: Lower Consumption Growth but Narrower Global Imbalances?” IMF Working Paper, forthcoming.

${ }^{3}$ See Athanasopoulou and Lundback, "Credit Conditions in Germany Following the Global Sub-Prime Crises," IMF Working Paper, forthcoming; Bundesbank, Monthly Report, September 2009.
} 
the recovery matures. While losses from securitized products have likely reached their peak, additional losses on non-performing loans, which follow GDP growth with a lag, could be significant. The Bundesbank estimates that by end-2010 German financial institutions are likely to write down another $€ 50$ billion to $€ 75$ billion from bad loans, adding to asset-related losses of $€ 10$ billion to $€ 15$ billion. ${ }^{4}$ This implies that about half of total losses have been written off, a ratio that tallies broadly with the IMF's October 2009 estimates for European banks overall. ${ }^{5}$ These losses - together with tighter capital regulations - will constrain credit supply during the recovery. Indeed, empirical evidence suggests that, in Germany, lending growth during the crisis has been positively related to initial bank capital, suggesting that capital could be a constraint on lending moving forward (Box 3).

\section{Weaknesses of bank}

\section{balance sheets could therefore}

hinder the recovery. Staff analysis suggest that negative shocks to credit supply would have large and lasting negative effects on real economic activity, in particular on gross fixed capital formation and private consumption. Thus, the possibility of a credit crunch is an important downward risk to the recovery.

\footnotetext{
${ }^{4}$ Bundesbank, Financial Stability Review, November 2009.

${ }^{5}$ The Global Financial Stability Report (GFSR), October 2009, estimates suggest that about 60 percent of total losses in Europe have been written off.
}

(Change in Logs)
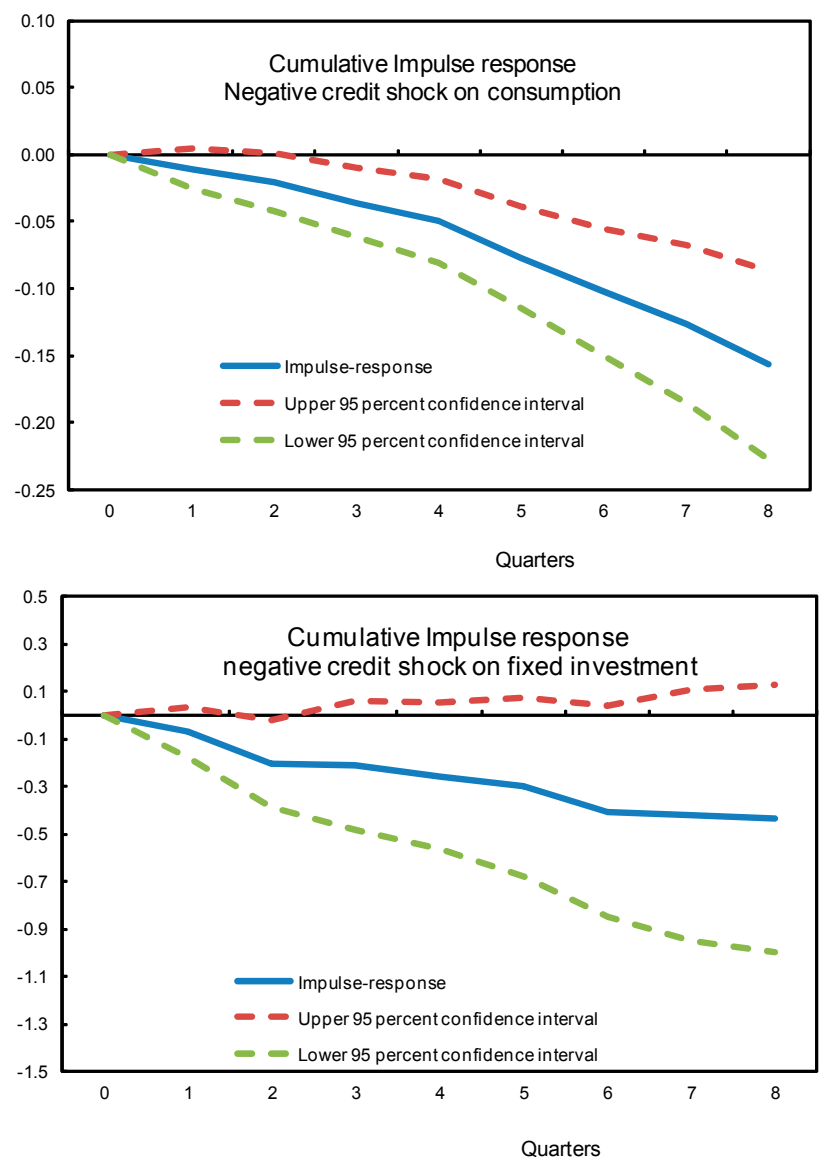
Each figure reports the cumulative impulse-response of a one standard deviation negative bank credit espectively consumption and on fixed investment. Each VAR, described in Box 3 , is estimated (1991:Q1-2007:Q4, and includes log(bank credit), log(employment), log(foreign im port demand for German exports), and log(REER). 


\section{Box 3. Bank Balance Sheets and the Recovery}

Since the start of the financial crisis, bank capital has weakened credit supply, adding to the decline in credit. Following the approach of Bernanke, Lown and Friedman (1991), staff estimated a relationship between lending growth and a measure of capitalization, defined as the ratio of capital to assets. ${ }^{1 /}$ The analysis is based on a panel of quarterly data over the period 2000-2009 in which bank balance sheets are aggregated in five categories (large commercial banks, other commercial banks, Landesbanken, savings banks, cooperative banks, and mortgage banks), and control variables include two measures of asset composition (cash over assets, and loans over assets). The results suggest that, since the crisis began, bank capital has become a constraint on lending growth, in contrast to the pre-crisis period. Moreover, the capital

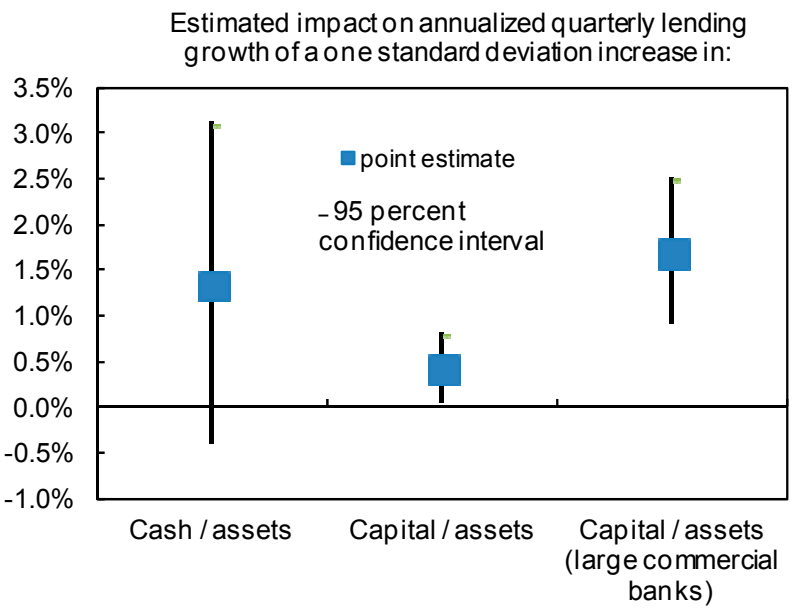

Source: IMF Staff estimates based on a quarterly panel data estimation over the period 2000-09 in which bank balance sheets are agg regated by type of banks. constraint appears to be stronger for the large commercial banks than for other banks. The effect of an increase in capital/assets on lending growth is economically significant, especially for the large commercial banks.

\section{A reduction in bank credit affects German macroeconomic activity significantly by reining} in private consumption and investment. Employing a simple time series analysis, staff assessed the impact of a reduction in bank credit on GDP, private consumption, and gross fixed capital formation. ${ }^{2 /}$ The quantitative effects of a reduction in bank credit on private demand are large: the estimated effects imply that a 1 percent reduction of bank lending would reduce consumption and investment by respectively 1.2 percent and 2.8 percent (text figure).

1/ Bernanke, Lown, and Friedman, 1991, "The Credit Crunch,” Brookings Papers on Economic Activity: 2, pp. 205-248.

2/ Specifically, three vector auto-regressions (VARs) of GDP, private consumption, and gross fixed capital formation, respectively, on bank credit were estimated, controlling for employment and a measure of import demand for German exports. The VARs are estimated at a quarterly frequency over 1991-2007. 


\section{Potential Growth}

\section{The authorities agree that the crisis has temporarily weakened Germany's} growth potential. Staff research suggests that potential growth has dropped to $1 / 3$ percent following several quarters of very weak investment and the scrapping of excess capacity in some areas (Box 4). The damage would have been more severe but for the slow adjustment of employment. Mirroring the labor market outlook, there are upside and downside risks. For example, the deterioration of the labor market could lead to higher and more longterm unemployment than anticipated, which could slow the projected gradual recovery of potential growth to its estimated longer-term value of around $1 \frac{1}{4}$ percent. But it seems equally likely that labor market conditions could develop better than expected.

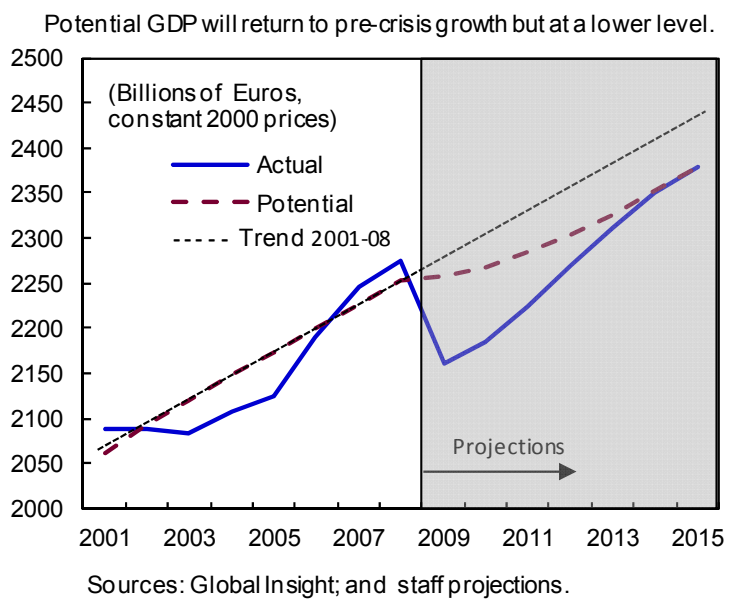

18. The slower expansion of potential growth will have repercussions for the speed of the recovery from the recession. Real activity is likely to run into capacity constraints earlier than otherwise, possibly leading to factor market tensions. This could trigger unwanted upward wage and price pressures.

\section{E. Inflation}

19. Against this background, inflation is expected to continue its gradual rise from the very low levels reached recently. Helped by the turnaround of global commodity prices, headline inflation is back in positive territory, averaging 0.2 percent in 2009 , compared with core inflation of 1.2 percent. With the level of actual output substantially below potential, headline inflation is projected to further increase only slowly, averaging about 0.9 percent in 2010 and 1.0 percent in 2011 - an outlook broadly shared by the authorities.

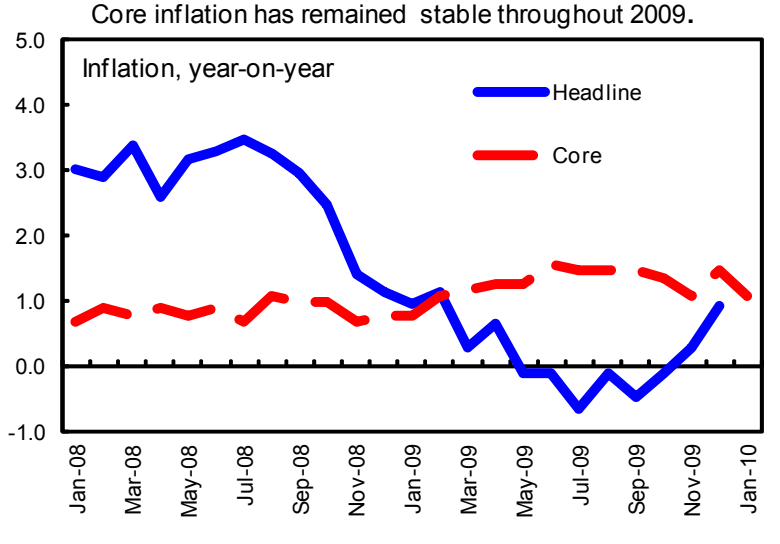

Sources: Eurostat, Haver, and Statistisches Bundesamt. 


\section{Box 4. The Effects of the Crisis on Potential Growth}

The financial crisis and the long recession have combined to lower Germany's potential GDP growth in the near and the medium term, but its longer-run trend will be little affected. ${ }^{1 /}$ Staff sees potential growth around 1.2 percent in the longer run (although there are indications that long-run growth could be on a downward path, reflecting, among other things, Germany's aging population). However, the impact of the crisis is likely to be shorter lived than elsewhere. While extraordinary financial sector productivity gains and profits added significantly to precrisis financial sector growth in some economies, Germany's financial sector showed little sign of overheating prior to the crisis. Thus, there is less need for adjusting long-run growth expectations in its aftermath.

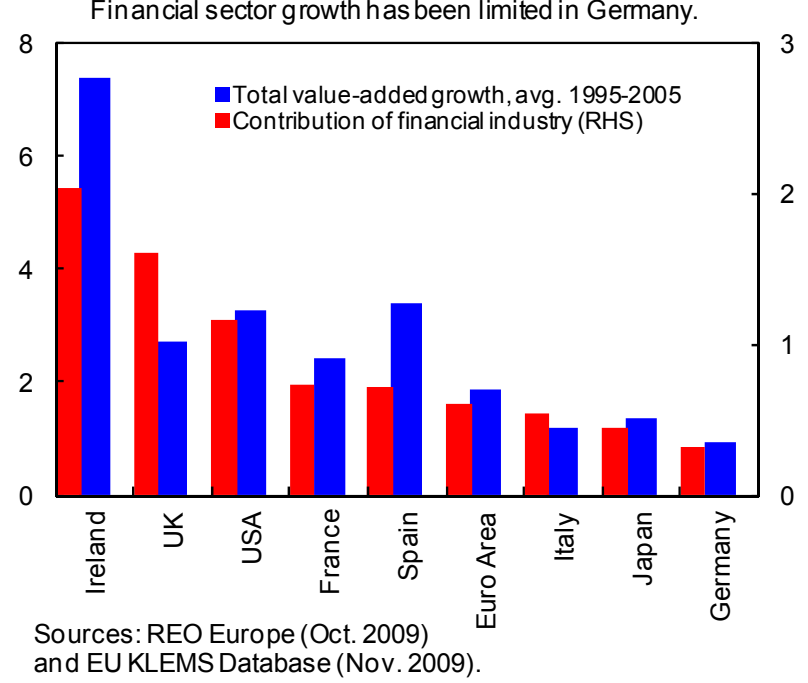

But the crisis will have a temporary negative impact on potential growth in the medium term.

In Germany and elsewhere, the crisis' impact on potential has been proportional to its impact on GDP.

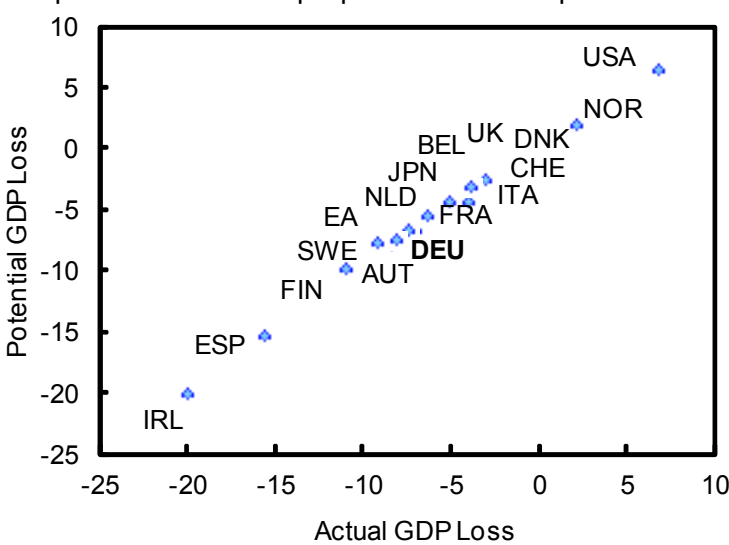

Source: IMF, WEO

Note: Data are calculated as the percent difference between projections for 2013 in the October 2009 WEO relative to those in the April 2008 WEO.
Like elsewhere, the effect arises from reductions in available input factor growth, through lower investment and a possible increase in structural unemployment, as well as from a reduction in productivity growth, especially labor productivity. Staff expects labor productivity to increase as firms adjust their workforce (see Box 2), and investment to pick up as the recovery matures, which will eventually increase potential growth back to pre-crisis levels. The implied permanent loss in the level of potential output is in line with the available cross-country evidence on the medium-term impact of recessions accompanied by financial crises on growth (see WEO October 2009, Chapter 4).

${ }^{1 /}$ This assessment combines judgment and technical analysis based on a Kalman filter methodology taking into account trend and cyclical variables correlated with potential growth and the output gap, respectively, including population growth, productivity, employment, investment and inflation. 


\section{Fiscal Policy: From Stimulus to Consolidation}

20. Fiscal policy has been counter cyclical. During 2008 and 2009, the authorities legislated fiscal stimulus measures amounting to 1.5 percent of GDP for 2009 and 0.4 percent of GDP for 2010; implementation lags suggest that a larger share of the measures will become effective this year. It is too early to evaluate the effectiveness of the stimulus overall. However, there are indications that the cash-forclunkers scheme had a

\begin{tabular}{lrrrr}
\multicolumn{4}{c}{ Fiscal Overview (percent of GDP) } \\
\hline & 2008 & 2009 & 2010 & 2011 \\
\hline Overall balance (general government) & 0.0 & -3.3 & -5.7 & -5.1 \\
Structural balance (general government) & -0.4 & -1.1 & -3.9 & -3.8 \\
$\quad$ Federal government & -0.7 & -1.0 & -2.9 & -2.5 \\
$\quad$ State governments 1/ & 0.1 & -0.4 & -1.5 & -1.6 \\
$\quad$ Social Security & 0.2 & 0.2 & 0.5 & 0.2 \\
Gross debt (general government) & 65.9 & 72.5 & 76.7 & 79.5 \\
\hline
\end{tabular}

Source: Authorities and IMF staff. $1 /$ Including local governments.

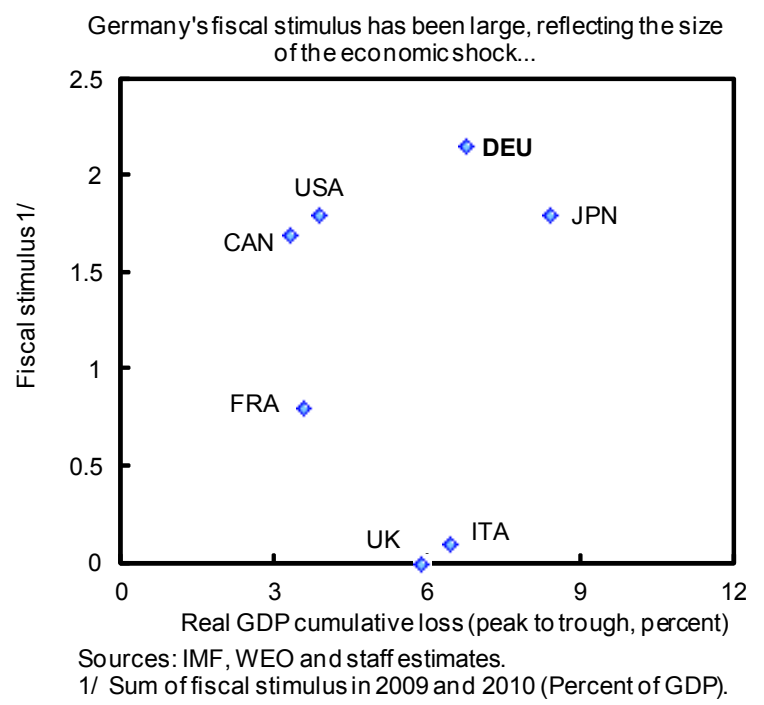

pronounced impact on private consumption during the first half of 2009 — although the stark decline in car sales after the scheme's expiration suggests that much of this effect was due to existing demand plans being moved in time (Box 5). The new government is committed to executing the remaining stimulus in the pipeline, and has added $1 / 4$ percent of GDP of new measures consisting of various tax rebates for businesses and higher family benefits for 2010 , bringing the overall stimulus for this year up to 0.7 percent of GDP. This is broadly consistent with the Fund's advice to maintain fiscal support until the recovery is firmly in place, even though the composition casts doubt on its effectiveness. In addition, the government's coalition agreement envisages permanent income tax cuts of about 1 percent of GDP in 2011.
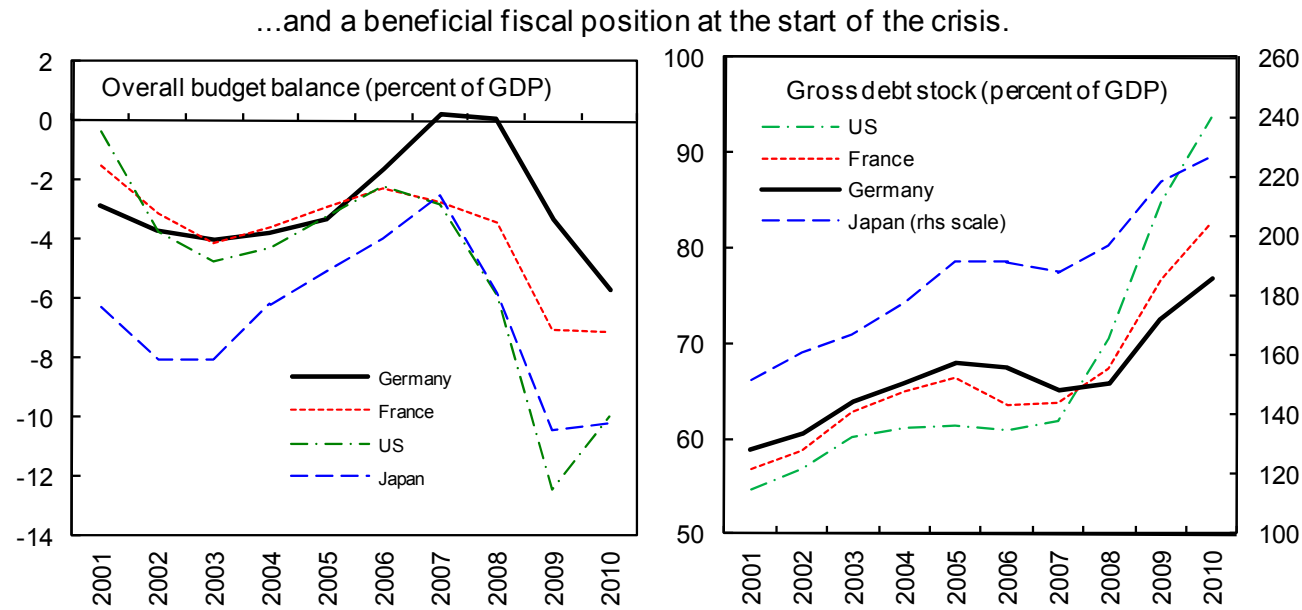

Source: October WEO, updated figures for Germany. 


\section{Box 5. Car-Scrapping Program}

The Cash-for-Clunkers scheme (CFC, "Umweltprämie") offered a subsidy of $€ 2,500$ for the purchase of new cars between January and August 2009. Following an overwhelming number of applications, the scheme's value was increased from the initial $€ 1.5$ billion to $€ 5$ billion $(0.2$ percent of GDP). Private consumption of cars jumped in Q1 and Q2 of 2009.

Staff estimates suggest that the CFC scheme boosted private consumption growth by 1.1 and 0.4 percentage points (qoq) in 2009:Q1 and Q2, respectively. A simple model explains the historical behavior of private expenditure on cars with a lag and disposable income. The spike in car sales during the first half of 2009 cannot be explained by the model. A dummy variable attributes a car consumption growth boost of 20 percentage points in each Q1 and Q2 to the CFC scheme. This effect translates into a positive contribution to total private consumption growth of 1.1 and 0.4 percentage points in 2009:Q1 and Q2, respectively.

\section{Estimates suggest that falling car sales already lowered private consumption} growth by 0.1 percentage point in Q3 - but

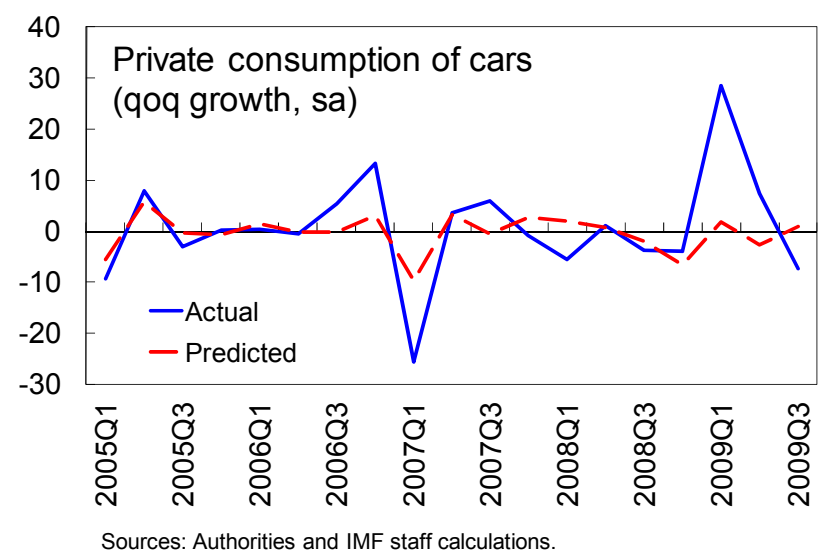
experience with the 2007 VAT increase suggests that more weakness is to come. In the run-up to the VAT increase in January 2007, car consumption jumped in late 2006, but the sharp decline in 2007:Q1 indicates that the previous increase was mostly driven by advanced car purchases. ${ }^{1 /}$

Consistent with the experience of the VAT episode, car sales have already started falling in 2009:Q3, shaving 0.1 percentage points off private consumption growth. More recent data indicate that car sales have continued to decline, contributing to weaker private consumption.

${ }^{1 /}$ The regression result shows that the announcement of the VAT increase raised car consumption growth by 9 percentage points in each 2006:Q3 and Q4, before the VAT increase reduced car consumption growth by 17 percentage points in 2007:Q1.

21. Consequently, the fiscal position has weakened markedly. Following a balanced budget in 2008, the general government deficit reached an estimated 3.3 percent of GDP in 2009 and is projected to increase to $5 \frac{1}{2}$ percent in 2010 - nearly twice the deficit limit set by the European Union's Stability and Growth Pact (SGP). The increased deficit reflects the additional budget measures, the fiscal consequences of the anticipated weakening of the labor market, and cyclically weak tax revenues. Taking into account the fiscal costs associated with the financial sector support packages, the gross debt ratio is set to rise from 65 percent of GDP in 2007 to 77 percent in 2010. 


\section{The authorities agree that fiscal consolidation needs to start as soon as the}

recovery has firmed up-which is projected for 2011. With public debt on a rising path, contingent liabilities associated with financial support measures, and private sector growth expected to become self sustaining by 2011, fiscal consolidation should become a priority.

\section{The authorities are firmly committed to meeting their medium-term fiscal}

targets. To fulfill the SGP requirement, the general government deficit will have to decline to 3 percent of GDP by 2013. By 2016, the general government budget will have to be close

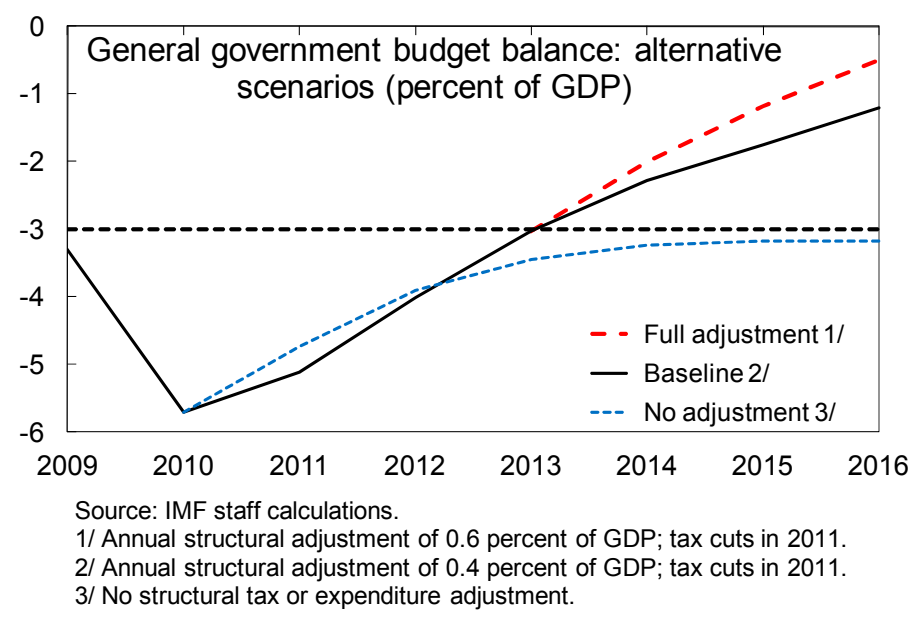

to balance, reflecting the limits Germany's new constitutional rule ("Schuldenbremse") and MediumTerm Objective (MTO) specified in the latest Stability Report impose on the structural deficits of the federal government and the Länder, respectively. ${ }^{6}$ Meeting these targets, which will require efforts from all levels of government, would allow Germany to regain the fiscal space lost to the crisis and prepare for the rising costs of its aging population.

24. Achieving these objectives will be a formidable task. While the economic recovery and the withdrawal of the stimulus measures will help reduce the general government deficit, additional adjustment is needed. According to staff's analysis, reaching the SGP goal will require an annual structural consolidation effort at the general government level of $1 / 2$ percent of GDP in 2011-13. ${ }^{7}$ Complying with the constitutional fiscal Germany: Historical Episodes of Consolidation (percent of GDP) 1/

\begin{tabular}{|c|c|c|c|c|c|c|}
\hline \multirow[b]{2}{*}{ Phase } & \multirow[b]{2}{*}{ Years } & \multirow{2}{*}{$\begin{array}{c}\text { Average } \\
\text { GDP growth }\end{array}$} & \multicolumn{2}{|c|}{ Structural balance } & \multicolumn{2}{|c|}{ Overall balance } \\
\hline & & & Total & Per year & Total & Per yea \\
\hline 1982-1985 & 4 & 1.6 & 3.6 & 0.9 & 2.8 & 0.7 \\
\hline 1992-1999 & 8 & 1.6 & 3.5 & 0.4 & 1.4 & 0.2 \\
\hline $\begin{array}{c}2004-2008 \\
\text { versus }\end{array}$ & 5 & 1.8 & 2.7 & 0.5 & 4.1 & 0.8 \\
\hline $2011-2016$ & & & & & & \\
\hline Baseline & 6 & 1.6 & 2.7 & 0.4 & 4.5 & 0.8 \\
\hline Full adj. & 6 & 1.6 & 3.4 & 0.6 & 5.2 & 0.9 \\
\hline
\end{tabular}
rule and MTO will require

Source: IMF staff calculations.

1/ Figures refer to the general government.

\footnotetext{
${ }^{6}$ The constitutional rule restricts the federal structural deficit to 0.35 percent of GDP by 2016 , and the MTO implies a structural deficit limit of 0.15 percent for the Länder. The structural deficits projected for 2010 are 2.9 and 1.5 percent, respectively.

${ }^{7}$ All scenarios assume that the federal government provides about 60 percent of the overall adjustment in line with the experience of earlier consolidation episodes.
} 
further annual structural adjustment of $3 / 4$ percent of GDP through 2016. Both calculations include the planned tax cuts in 2011. The required fiscal efforts are large and comparable to the re-balancing of the public finances after German unification, and the pre-crisis drive for a balanced budget.

\section{Formulating a credible fiscal adjustment strategy—focused on expenditures-} and implementing it starting in 2011 will be important. Expenditure-based consolidations tend to be larger and more enduring, ${ }^{8}$ and the authorities agreed that such an approach was preferable. International evidence also shows that fiscal adjustments cause the smallest contractionary effects when driven by reductions in current spending. ${ }^{9}$ The authorities agreed that measures introduced during the crisis need to be withdrawn as planned, but additional efforts will be required. While progress has been made in reducing subsidies under the previous government, staff stressed that the planned further systematic examination of subsidies (for example, in agriculture or mining) can yield budgetary savings. Staff also saw it as crucial to strictly adhere to the agreed-upon adjustment mechanisms for pension benefits and the gradual rise in the retirement age. The ongoing effort to realize potential savings in the health care system (for example, by limiting spending on non-generic pharmaceuticals) should also help.

\section{But the authorities are well aware that the need for consolidation might exceed} the scope for expenditure cuts, in which case revenue measures will also be needed. Staff suggested that a first step could be to broaden the VAT tax base by eliminating exemptions, including those recently introduced, and increasing coverage. Staff also recommended reviewing income tax exemptions. If tax rate increases were unavoidable, higher VAT rates would prop up revenues at the federal and Länder levels, and a reform of the property tax could support local finances. Also, an increase of contribution rates to the unemployment insurance would remove the need for repeated federal government supporta proposal that is under discussion.

\section{In this context, tensions in the fiscal plans for 2011 need to be resolved. The} coalition agreement includes a permanent income tax cut of about 1 percent of GDP. The authorities pointed out several arguments in its favor: well-timed tax cuts can help sustain private demand and the recovery; the implied lowering of marginal tax rates could increase incentives to work; and the envisaged simplification of the income tax system (including a move from the existing linearly increasing income tax schedule to one with stepwise constant

\footnotetext{
${ }^{8}$ Guichard and others, 2007, "What Promotes Fiscal Consolidation: OECD Country Experiences," OECD Economics Working Paper No. 553.

${ }^{9}$ Kumar and others, 2007, "Fiscal Adjustments: Determinants and Macroeconomic Consequences," IMF Working Paper 07/178. On the revenue side, consumption tax increases tend to have the smallest growth impact.
} 
rates) promises further efficiency gains. While agreeing with these potential benefits, staff noted that the impact on labor supply may be small and that the proposed income tax schedule could create adverse incentive effects, such as those associated with bunching around the tax rate steps. Moreover, the tax cuts in 2011 would add to the already elevated debt level at a time when the recovery has likely already firmed, giving them a distinctly procyclical character. This suggests that any tax measure should be carefully designed to maximize its intended efficiency impact and should be implemented only if compensating budgetary measures were taken to ensure compliance with the medium-term fiscal targets.

28. The authorities are well aware that a successful fiscal exit will not only establish the credibility of the new national fiscal framework, it will also help anchor fiscal policy in the euro area. Germany's fiscal actions matter in Europe because of the country's relative size and because, as in the past, they could set an example for fiscal consolidation for the rest of Europe (Box 6). This would reduce the risk of an undesirable policy mix of tight monetary and loose fiscal policy (which tends to increase interest rates and crowd out private demand) in the euro area, which in turn would weaken growth in Germany. Conversely, a failure to consolidate the public finances in Germany would damage the national and European fiscal frameworks.

\section{FinANCIAL SECTOR}

\section{A. Completing the Banking Consolidation}

29. The health of the financial sector has improved, but time is running short for dealing with the remaining problems and risks. The steepening yield curve, the improving economic outlook, and the authorities' financial sector measures have benefited banks. Some of Germany's larger banks have deleveraged their balance sheets and added to their capital. Still, the remaining sizable write-downs, along with risks to the recovery and banks' exposure to emerging and Southern European markets, create vulnerabilities. With the expected tightening of euro area liquidity, the window for resolving remaining financial sector problems is closing fast. The sunset clauses for new public support through the Sonderfonds Finanzmarktstabilisierung (SoFFin) by end-2010 add to the urgency (Box 7).

30. Recognizing capital needs at the individual bank level and acting upon it will be

key. As the authorities pointed out, the voluntary public recapitalization option offered by SoFFin has been helpful in this regard. However, fewer institutions than initially expected have made use of the offer, suggesting - in staff's view - that more forceful incentives to strengthening capital buffers might be needed. Stronger institutions could make use of the normalization of equity markets. Weaker banks will have to accept the conditionality of SoFFin's support, or face resolution. In line with the principles established by SoFFin, public support will be conditional on viable business models - a condition particularly relevant for the Landesbanken sector. 


\section{Box 6. Fiscal Spillovers in the Euro Area}

Staff's research shows that Germany's fiscal actions have had positive spillovers into member states since the creation of EMU. ${ }^{1 /}$ Empirically modeling the reaction of fiscal indicators to a number of economic and policy variables for a panel of 11 euro area members, staff show that Germany's discretionary fiscal policy has had a strong and robust influence on discretionary fiscal actions in the rest of the euro area since 1992. The text chart displays the estimated policy spillover parameter and its error bands - it measures the reaction of the average euro area country to changes in Germany's fiscal policy across different time samples using a rolling ten-year window.

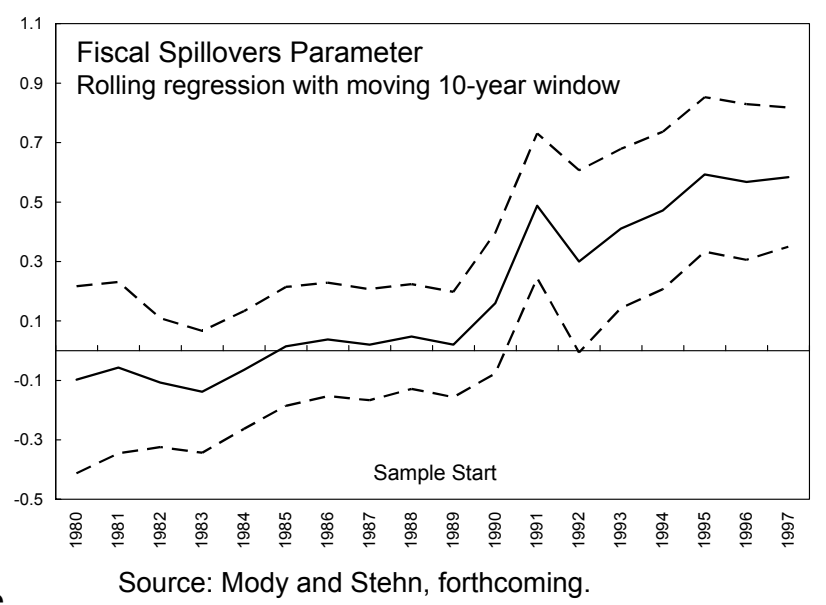

\section{Fiscal credibility seems to explain part of the}

Source: Mody and Stehn, forthcoming

effect. Indeed, the pattern of country responses to Germany's actions suggests that the wish to signal credibility plays a role. Countries with higher political instability and more acute economic vulnerabilities have responded more strongly to Germany's actions. This effect was particularly strong during periods of German fiscal consolidation.

${ }^{1 /}$ See Mody and Stehn, Fiscal Policy in the Euro Area: Does Germany Play a Leadership Role? IMF Working Paper, forthcoming.

31. The larger public banks remain an area of particular concern. The financial crisis has revealed serious and systemic risks to financial stability in the Landesbanken sector. After government help in various forms for various Landesbanken (see text figure), Germany's largest Landesbank, West LB, will undergo more substantial restructuring. About one third of its balance sheet (€85 billion, including structured products) will be transferred to a "bad bank," with the remaining core bank receiving about $€ 3$ billion public capital from SoFFin, initially as silent participation. Bayern LB's financial position has been weakened by its past, and costly, ownership of Austrian Hypo Group Alde Adria. 


\section{Box 7. The German Financial Market Stabilization Fund (SoFFin)}

The Sonderfonds Finanzmarktstabilisierung was set up in October 2008 and is administered by the Agency for the Stabilisation of the Financial Markets (Bundesanstalt für

Finanzmarktstabilisierung, $\boldsymbol{F M S A}$ ). Its purpose is to facilitate financial sector stabilization measures supporting financial institutions (such as banks, insurance companies, pension funds, investment companies, and special purpose vehicles) based in Germany. Stabilization measures are decided by the Ministry of Finance (which delegated certain decisions to FMSA), and the Ministry regularly informs a special parliamentary committee. In its operations, SoFFin draws on some support from the Bundesbank and external expertise.

The available stabilization measures comprise guarantees, recapitalizations, and the transfer of risky assets, including "bad banks." The total volume of these measures is capped at $€ 480$ billion, with up to $€ 400$ billion available for guarantees for interbank loans and bank-issued debt with a maturity of generally up to 3 years, and $€ 80$ billion for the recapitalizations and the assumption of risk associated with certain assets. The federal government provides the funding of the SoFFin. After the liquidation of the SoFFin, the remaining position is to be divided to 65 percent to the federal government and 35 percent to the states (capped at $€ 7.7$ billion, though costs associated with the Landesbanken are to be borne in full by the relevant states).

\section{The uptake of SoFFin financial} sector support measures has been large. By December 2009, about 40 percent of the available funds had been used ( 40 percent of the guarantees and 37 percent of the other measures) and another 19 percent of the available fund

Financial Crisis Measures in Comparison 1/ (In percent of GDP)

\begin{tabular}{|c|c|c|c|c|c|c|}
\hline & \multicolumn{2}{|c|}{ Guarantees } & \multicolumn{2}{|c|}{ Recapitalization } & \multicolumn{2}{|c|}{ Asset Purchase } \\
\hline & Pledged & Used & Pledged & Used & Pledged & Used \\
\hline Germany & 16.6 & 6.7 & 3.3 & 1.2 & 0.4 & 0.2 \\
\hline U.S. & 11.0 & 2.2 & 5.2 & 2.4 & 0.0 & 0.0 \\
\hline U.K. & 54.5 & 7.0 & 3.9 & 3.3 & 0.0 & n.a. \\
\hline France & 16.4 & 6.0 & 1.4 & 0.8 & 0.0 & n.a. \\
\hline
\end{tabular}

Sources: WEO; IFS; and IMF staff estimates.

1/ As of end-December, 2009 (Germany) and end-August, 2009 (others).

Notes: Pledges based on announcements by official agencies, supplemented by information from financial market sources. Guarantees cover asset loss or financial institutions' debt, such as senior unsecured debt. Recapitalization includes purchases of shares or hybrid capital instruments that constitute tier I capital. Asset swaps and purchases include government purchases of assets held by financial institutions or exchange for government debt.

had been requested.

Besides Germany, the U.K. and Switzerland have established specific entities (with a temporary mandate) to resolve the distress of its financial system. U.K. Financial Investments Limited was established in November 2008 as a company wholly-owned by the Government. Its aim is to manage the Government's equity participations in financial institutions at arm's length and on a commercial basis, to ensure financial stability, and to act in a way that promotes competition. Switzerland has established a Stabilization Fund as a separate entity that is closely linked to the Swiss National Bank to handle the illiquid assets of a large bank. Other countries that have experienced highly adverse shocks to their financial stability have handled the crisis with existing institutions, for instance in the U.S. through the Federal Reserve and the FDIC. 


\section{This suggests that consolidation of the Landesbanken sector should be a policy}

priority. The authorities are well aware of - and staff has noted in the past - many of the sector's underlying problems, including the structural unprofitability, weak governance, and insufficient risk control that are burdening many institutions. ${ }^{10}$ Staff noted that the structural unprofitability will remain even as the outlook improves: with their high cost structure and lack of a viable business model, some Landesbanken will continue to show a tendency for excessive risk taking in search of profits. Thus, despite initial steps towards restructuring, much more needs to be done to prevent the Banking Sector-Performance and Soundness Indicators: Selected Countries, end 2008

\begin{tabular}{lrrrrrrr}
\multicolumn{1}{c}{ (In percent) } & \multicolumn{1}{c}{} \\
\hline Bank regulatory capital to risk-weighted assets & France & Italy & Japan & Spain & U.K. & U.S. & Germany \\
\hline Bank capital to assets & 5.3 & 6.1 & 11.6 & 11.0 & 10.4 & 12.8 & 11.0 \\
Tier 1 capital ratio & 8.1 & 5.8 & 8.3 & 7.9 & 6.5 & 9.0 & 8.3 \\
Bank return on average assets & 0.0 & 0.4 & 0.3 & 0.7 & 0.0 & -0.2 & -0.3 \\
Bank return on average equity & 1.1 & 5.0 & 5.3 & $\ldots$ & 0.5 & -1.9 & -9.2 \\
Net loans to total assets & 36.1 & 63.5 & 44.0 & 67.2 & 36.4 & 52.0 & 30.2 \\
Liquid assets to customer and ST funding & 80.0 & 32.4 & 11.5 & 19.5 & 41.3 & 32.4 & 44.5 \\
Non-performing loans to total loans & 2.1 & 5.3 & 3.2 & 3.0 & $\ldots$ & 2.3 & $\ldots$ \\
Loan loss provisions to non-performing loans & 28.0 & 13.4 & 9.9 & 28.2 & $\ldots$ & 37.3 & $\ldots$ \\
\hline
\end{tabular}

Sources: Bankscope; and IMF staff calculations. U.S. and German data shows consolidated reports for banking groups, other data also unconsolidated reports for other banks. The aggregate capital adequacy ratio and Tier 1 ratio are the weighted average of individual banks CAR and Tier 1 ratio with 2008 assets as weighs, and for the 25 largest banking groups in each country for which 2008 consolidated accounts are available. sector from being a continuous drain on the public finances and a source of financial instability for Germany. While the authorities supported the need for significant consolidation of the sector, they also stressed that the ownership of the Länder limits the influence of the federal government on the process. The authorities and staff saw the Landesbanken's wholesale banking function for Sparkassen as a basis for consolidation, with staff suggesting a single institution. Any remaining Landesbanken would need to have effective governance and viable business models, with an alternative private ownership structure.

\section{Quickly solving the remaining financial sector problems at the individual bank}

level will also allow exiting from blanket measures. Measures such as the support for bank funding offered by SoFFin and the government's public commitment to fully protect household deposits can distort risk-taking incentives and prevent market normalization. This calls for an exit as soon as all known and anticipated recapitalization needs have been met. The forthcoming FSAP Update requested by the authorities and scheduled for late 2010 can be helpful by shedding light on the financial sector's health in the absence of government support. Enhanced surveillance of the German banking sector would profit from more comprehensive and timely data and transparent reporting.

\footnotetext{
${ }^{10}$ See, for example, the 2003 Germany FSAP and Section IV.A in IMF, 2009, Germany: 2008 Article IV Consultation: Staff Report, IMF Country Report No. 09/15.
} 
34. It will be important to coordinate the exit from these financial sector measures internationally. For example, an uncoordinated withdrawal or amendment of deposit guarantees at the national level could trigger unwanted cross-border capital flowssimilar to the early crisis phase, when highly liquid funds chased the highest deposit guarantee across Europe. To limit these risks, Germany will benefit from (and could be part of) a coordinated exit at the EU level.

\section{B. The Financial Stability Framework}

\section{The authorities are moving to} overhaul the financial stability framework. Key elements of the reform are banking supervision and the bank resolution regime, while further changes to the fragmented deposit insurance system are not on the agenda. Ongoing EU reforms are providing the backdrop to the German efforts.

\section{The government plans to consolidate all prudential banking supervision into the Bundesbank.}

Germany: Key Measures in Response to the Financial Crisis

\begin{tabular}{|c|c|}
\hline \multicolumn{2}{|l|}{2007} \\
\hline Aug. & $\begin{array}{l}\text { IKB receives } € 3.5 \text { bn from public and private banks. Sachsen LB } \\
\text { receives credit line of } € 17 \text { bn from savings bank group and } \\
€ 2.75 \text { bn in guarantees from the state of Saxony. }\end{array}$ \\
\hline Dec. & Landesbank Baden-Württemberg takes over Sachsen LB. \\
\hline \multicolumn{2}{|r|}{ ( } \\
\hline Mar./Apr. & West LB receives $€ 5$ bn first loss guarantee from its owners. \\
\hline July & $\begin{array}{l}\text { KfW agrees to sell its } 90 \text { percent share of IKB to investor Lone } \\
\text { Star. }\end{array}$ \\
\hline Sept. & $\begin{array}{l}\text { BaFin prohibits naked short-selling of selected instruments. } \\
\text { Hypo Real Estate receives liquidity support with package worth } \\
€ 35 \text { bn from the Federal government, banks, and financial sector } \\
\text { firms to prevent collapse. }\end{array}$ \\
\hline Oct. & $\begin{array}{l}\text { Hypo Real Estate package increases to } € 50 \text { bn. Government } \\
\text { announces public commitment to fully protect household } \\
\text { deposits. Finanzmarktstabilisierungsgesetz is passed creating } \\
\text { SoFFin and providing framework for } € 480 \text { bn in guarantees, } \\
\text { recapitalizations, and asset purchases. }\end{array}$ \\
\hline Nov. & $\begin{array}{l}\text { Commerzbank receives } € 15 \text { bn in guarantees and } € 8.2 \text { bn in the } \\
\text { form of a silent participation from SoFFin (at end-2008). Bayern } \\
\text { LB receives } € 4.8 \text { bn in guarantees and } € 10 \text { bn in capital from } \\
\text { state of Bavaria. }\end{array}$ \\
\hline \multicolumn{2}{|r|}{ ( } \\
\hline Jan. & $\begin{array}{l}\text { Commerzbank to receive additional } € 10 \text { bn from SoFFin made } \\
\text { up of a silent participation amounting to } € 8.2 \text { bn and a capital } \\
\text { increase of } 25 \text { percent of ordinary shares plus one share held by } \\
\text { the Federal government against payment of } € 1.8 \mathrm{bn} \text {. }\end{array}$ \\
\hline Feb. & $\begin{array}{l}\text { HSH Nordbank receives } € 3 \text { bn in capital and } € 10 \text { bn in } \\
\text { guarantees from states Hamburg and Schleswig-Holstein. Hypo } \\
\text { Real Estate support reaches total of } € 52 \text { bn in guarantees from } \\
\text { SoFFin. }\end{array}$ \\
\hline March & $\begin{array}{l}\text { HSH Nordbank receives } € 30 \text { bn in guarantees from SoFFin. } \\
\text { SoFFin buys shares in Hypo Real Estate worth } € 60 \text { million. }\end{array}$ \\
\hline April & $\begin{array}{l}\text { Finanzmarktstabilisierungsergänzungsgesetz is passed, } \\
\text { including an option for public takeover of banks as a last resort. } \\
\text { SoFFin buys shares in Hypo Real Estate worth } € 124 \text { million. } \\
\text { Landesbank Baden-Württemberg receives } € 5 \text { bn in capital and } \\
€ 12.7 \text { bn in guarantees from state Baden-Württemberg. }\end{array}$ \\
\hline May & BaFin extends prohibition of naked short-selling. \\
\hline June & SoFFin to provide $€ 2.96$ bn in capital to Hypo Real Estate. \\
\hline July & Bad-Bank-Act is passed. \\
\hline Oct./Nov. & $\begin{array}{l}\text { Hypo Real Estate is nationalized after squeezing out } \\
\text { shareholders with compensation of } € 158 \text { million and receives } \\
\text { additional } € 3 \text { bn in capital from SoFFin, with guarantees } \\
\text { extended until end-June } 2010 \text {. }\end{array}$ \\
\hline Dec. & $\begin{array}{l}\text { Bad bank created for West LB to take on } € 85 \text { bn portfolio of } \\
\text { assets. West LB core bank to receive capital support from } \\
\text { SoFFin. }\end{array}$ \\
\hline
\end{tabular}

Sources: Authorities; and IMF staff. Currently the Bundesanstalt fur Finanzdienstleisungsaufsicht (BaFin, the consolidated supervisor for the German financial sector) and the Bundesbank share duties for bank supervision. The Bundesbank performs on-site supervision under instructions issued by BaFin, but BaFin can commission special audits of banks and has overall responsibility for the supervision of banks. The arrangement has been criticized - including by staff - as duplicative and creating coordination and informational issues, creating delays in taking enforcement actions, and weakening accountability and potentially leading to poor decision making. Against this background staff welcomed the planned reform as a step in the right direction. 


\section{The authorities are discussing a variety of organizational models to implement}

the reform. Staff stressed that no one arrangement has worked consistently better across countries in preventing the crisis. ${ }^{11}$ However, the crisis has also highlighted the need for any model to ensure the incentives and capability to identify and address systemic risks. To this end:

- $\quad$ The authorities agreed that having one national agency with a clear mandate for macroprudential oversight and monitoring systemic risk would have benefits. The Bundesbank is the natural choice in this regard, given its experience in banking supervision and financial stability analysis. The discussion about the Bundesbank's sectoral coverage is ongoing, however. In staff's view, placing prudential supervision over the entire financial sector - in particular not only banking but also insurance given their interconnectedness in Germany - under the Bundesbank would facilitate both this process and the Bundesbank's ability to represent Germany on the proposed European Systemic Risk Board. BaFin would then become the market conduct supervisor, with responsibility for securities firms and markets and consumer protection for the entire financial sector - an arrangements resembling the so-called twin peaks model.

- $\quad$ Regardless the specific responsibilities given to the Bundesbank, staff stressed the resulting body would have to be both accountable and operationally independent to deliver effective supervision.

- $\quad$ The authorities stand ready to manage the transition risks to avoid supervisory lapses. Given the possibility that the merger and reorganization could well distract personnel from their primary mission, staff suggested it was critical to clarify early the form of the final reorganization and prepare for speedy implementation by early 2011 .

38. The authorities also seek to strengthen the legal framework for bank resolution. The global financial crisis has reinforced the need for countries to have strong and effective regimes for bank resolution. Building on the temporary measures taken with the creation of SoFFin, the authorities have begun to develop a legal framework for resolving systemically important banks in an orderly fashion. As discussed at the European level, this framework should allow for bridge banks and transactions involving the assumption of liabilities and the purchase of assets. While the authorities saw little need for a special regime to allow for the orderly exit of non-systemic banks, staff stressed the slowness and potential disruptiveness of existing corporate insolvency procedures. The authorities agreed that having a permanent bank resolution regime in place by early 2011 would have advantages, given the sunset

\footnotetext{
${ }^{11}$ See the initial discussion in Nier, 2009, "Financial Stability Framework and the Role of Central Banks: Lessons from the Crisis," IMF Working Paper 09/70.
} 
provisions for SoFFin. In case of a delay, staff recommended SoFFin's powers should be extended as long as needed.

\section{The crisis has exposed long-standing limitations of the German deposit} insurance regime, strengthening the case for more fundamental reform. As staff has highlighted in the past, German deposit insurance is highly fragmentized, reflecting the public-private mix of the banking system. ${ }^{12}$ Commercial banks combine a statutory scheme providing coverage of $€ 50,000$ with additional collective arrangements. Cooperative banks rely on collective arrangements and Sparkassen and Landesbanken on a combination of collective arrangements and support from their public sponsors - and neither group is currently subject to a statutory scheme. While the authorities saw the existing regime as adequate, staff pointed out the lack of transparency and legal certainty and stressed that the high coverage can be difficult to maintain without public support - a point vividly illustrated by the need for a $€ 6.7$ billion SoFFin guarantee for the commercial banks' deposit protection scheme during the crisis. In addition, the association-sponsored deposit protection schemes rely largely on after-the-fact contributions from members at the time of stress, which can exacerbate a crisis. With the EU-initiated further increase of statutory deposit insurance coverage to $€ 100,000$ next year, staff saw merit in creating a unified fund for deposit insurance spanning the entire banking system.

\section{Adjusting Structural Policies}

40. With the recovery firming up, labor policy measures and state aid introduced to soften the crisis' impact have served their purpose. The enhancements of Kurzarbeit

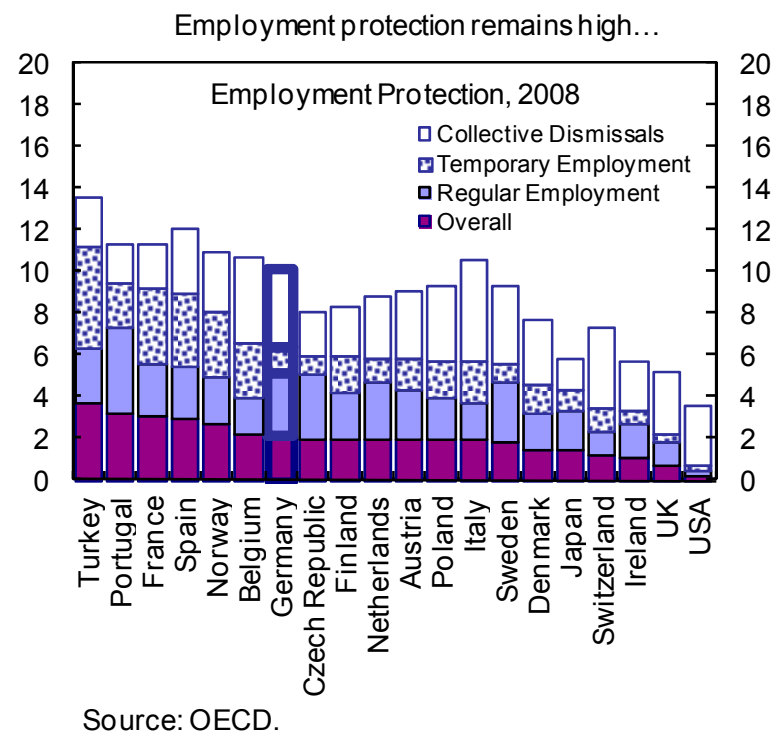

during the crisis, and the support for struggling corporations through targeted $K f W$ credit programs and the Deutschlandfonds (a credit fund installed as part of the stimulus measures), have contributed to limiting the initial crisis impact on employment. This has helped the hard-hit manufacturing sectorwith some struggling corporations benefiting both from credit arrangements and the shorttime work scheme. But the authorities are well aware that it will be important to adjust these policies to the cycle to avoid impediments for structural change and

\footnotetext{
${ }^{12}$ See Box 3 in IMF, 2009, Germany: 2008 Article IV Consultation: Staff Report, IMF Country Report No. 09/15.
} 
longer-run growth. For example, industry analysts argue that the car industry in Western Europe is characterized by excess capacity beyond the immediate effects of the crisis. ${ }^{13}$ Thus, it will be crucial to draw a line between smoothing the impact of the shorter-term repercussions of the global recession and preventing what could be a necessary adjustment to longer-term trends in demand. Staff therefore supported the government's intention to adjust the conditions of the Kurzarbeit scheme in line with the pace of the recovery.

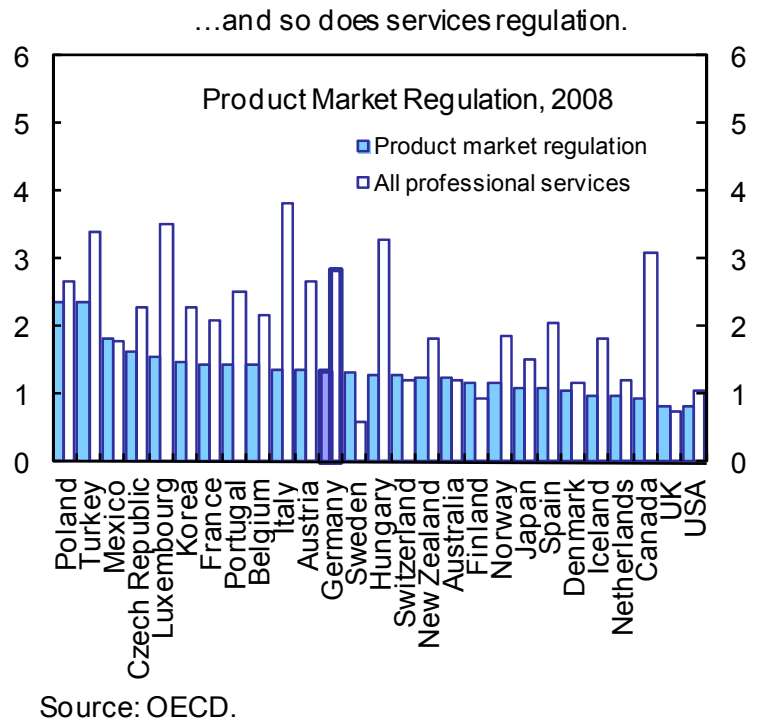

\section{The authorities agreed that payoffs from adjusting structural policies more} generally are high - but saw little opportunity for major additional reforms in the near term. Given the projected increase in unemployment, the damage from the crisis to potential growth, and the expectation of more moderate export demand, it will be essential to add to the gains from past reforms. In particular, further increasing labor market flexibility through decreasing both legal and labor-court based employment protection would support the reallocation of workers across sectors, while tackling remaining obstacles to service sector growth would boost labor demand. The product market reforms currently discussed by the authorities - ranging from enhanced powers for the competition authority to measures to enhance competition in network industries - will also be beneficial. Simultaneous reforms in all areas are promising additional benefits, as firms operating in more competitive product or services markets tend to react more strongly to labor market reforms than others. While agreeing that there was scope for additional reforms, the authorities noted the political window to implement had narrowed, with the current public debate focused more on the costs than the benefits of past structural reforms.

\section{SPILlOVERS}

\section{Compared to the other large European countries, Germany is a remarkably} open economy and particularly exposed to foreign shocks. Germany is highly integrated into global trade, and even more into the intra-European and euro area flow of goods and services. External volatility therefore adds considerably to the volatility of GDP overall. Germany's larger banks, too, operate globally and across Europe's financial market. Between 2000 and the first quarter of 2008 alone, foreign claims of German banks rose by the equivalent of 37 percentage points of GDP, and foreign exposure remains high despite the

\footnotetext{
${ }^{13}$ OECD, "The Automobile Industry in and Beyond the Crisis," OECD Economic Outlook, November 2009.
} 
deleveraging during the crisis period (Box 8).

Germany is more exposed to EU and non-EU trade shocks than its larger neighbors, but financial openness is average.

Real and financial links to emerging Europe are substantial, including through export demand, the integration of manufacturers in the German supply chain, and banking exposure. German banks have close to 5 percent of their foreign portfolio invested in Central and Eastern European countries, which exceeds the investment by banks in the U.S., the U.K., or France.

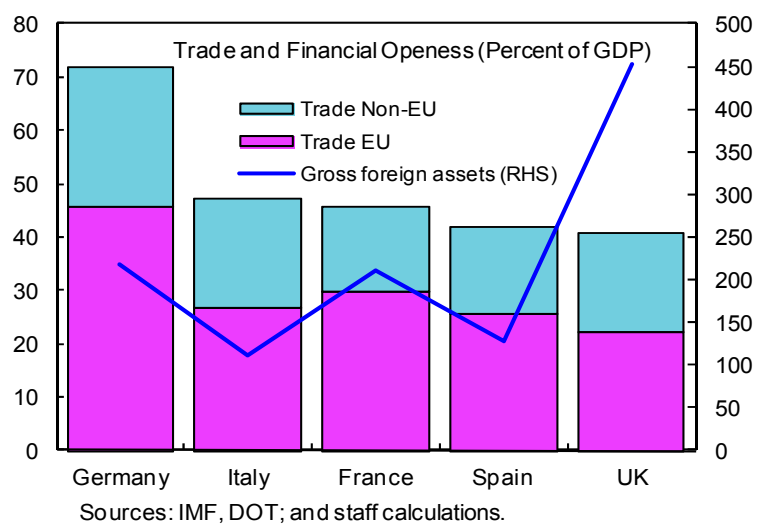

Significant write-downs of German banks' foreign exposures to Southern Europe or Central and Eastern Europe would likely feed back into a deleveraging and contraction of these exposures. 1/ (Billions of U.S. dollar)
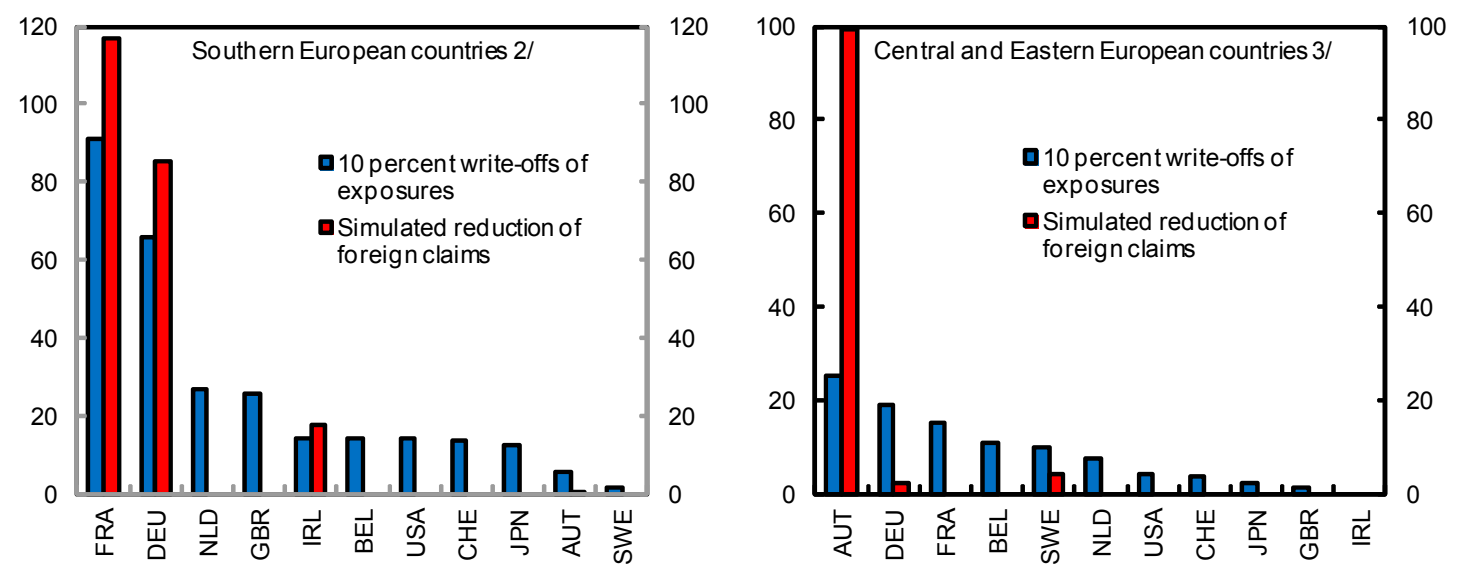

Source: BIS; and IMF staff calculations.

1/BIS consolidated banking statistics and IMF staff simulations based on a model of international banks' deleveraging developed for the purpose of the Vulnerability Exercise for Advanced countries and the Early Warning Exercise. The reduction of foreign claims of international banks is simulated based on 10 percent write-offs of exposures to the set of countries considered, and takes into account banks' initial capital buffer.

2/ Greece, Italy, Portugal , and Spain.

3/ Albania, Belarus, Bosnia and Herzegovina, Bulgaria, Croatia, Czech Rep, Estonia, Hungary, Latvia, Lithuania Poland, Romania, Russia, Serbia, Slovakia, Slovenia, and Ukraine.

\section{This reinforces the case for strengthening domestic sources of growth, which} could also contribute to lower current account imbalances-both globally and within

the euro area. Staff agreed with the authorities that the rebalancing should not occur through policies to weaken German competitiveness - a move likely to reduce euro area competitiveness overall. Within the euro area relative prices will have to adjust to prevent continued imbalances and safeguard growth. For Germany, the way forward would be additional labor reforms and efforts to bolster service sector activity to aid long-run growth. In addition to benefiting Germany more generally, this could help to reduce Germany's 


\section{Box 8. Foreign Exposure of German Banks}

Prior the crisis, foreign claims of German banks grew at a rapid pace. From 2000:Q1 to 2008:Q1, foreign claims of German banks rose by 160 percent to about $\$ 4.7$ trillion (a change in the foreign claims to GDP ratio of about 37 percentage points). About half of the build-up of foreign claims of German banks during this period went to the euro area and to the U.S., while emerging markets accounted for 8 percent of the increase.

The crisis triggered a deleveraging partly driven by risk perceptions. Between March 2008 and the end of June 2009, foreign claims of German banks contracted by $\$ 1.2$ trillion - exceeding the decline in other advanced countries. ${ }^{1 /}$ The bulk of this reduction occurred vis-à-vis other advanced countries, in particular with the U.S. and the euro area. Within the euro area, Southern Europe - namely Greece, Italy, Spain, and Portugal - took a significant part of the adjustment. At the same time, claims toward Central and Eastern Europe (CEE) contracted only modestly, possibly as a result of the Vienna initiative or of banks' objective to maintain their presence in CEE countries.

But German banks remain exposed to foreign risks. Simulation exercises suggest that German banks could suffer significant losses from commercial real estate investments in the U.S. and Spain, and more generally from exposures to Southern Europe. The simulations also suggest that a reassessment of risks associated with claims on Southern Europe could have a large impact on capital flows within Europe, as German Geographical Distribution of Foreign Claims of International Banks (In percent of total, unless otherwise indicated)

\begin{tabular}{|c|c|c|c|c|c|c|c|c|}
\hline \multirow[t]{2}{*}{ Banks from: } & \multicolumn{2}{|c|}{ Germany } & \multicolumn{2}{|c|}{ France } & \multicolumn{2}{|c|}{ U.K. } & \multicolumn{2}{|c|}{ U.S. } \\
\hline & 2008:Q1 & 2009:Q2 & 2008:Q1 & 2009:Q2 & 2008:Q1 & 2009:Q2 & 2008:Q1 & 2009:Q2 \\
\hline All countries (in billion US\$) & 4,673 & 3,462 & 4,251 & 3,567 & 4,002 & 3,689 & 1,748 & 2,577 \\
\hline United States & 17.5 & 17.3 & 19.0 & 19.1 & 33.3 & 32.8 & $\ldots$ & $\ldots$ \\
\hline Euro area & 37.6 & 40.5 & 41.1 & 42.7 & 30.9 & 27.4 & 26.1 & 26.1 \\
\hline Of which: Southern Europe & 14.6 & 15.1 & 20.6 & 21.9 & 6.9 & 6.4 & 5.3 & 4.6 \\
\hline Emerging markets & 8.6 & 9.3 & 8.6 & 9.5 & 10.7 & 11.4 & 25.0 & 18.7 \\
\hline Of which: CEE countries & 4.8 & 6.0 & 4.2 & 4.6 & 0.1 & 0.4 & 3.2 & 2.3 \\
\hline Rest of the world & 36.3 & 32.9 & 31.3 & 28.7 & 25.1 & 28.4 & 49.0 & 55.1 \\
\hline
\end{tabular}

Source: BIS Consolidated Banking Statistics.

Note: Southern Europe includes Greece, Italy, Portugal, and Spain. Emerging markets are countries included in the Vulnerability Exercise for Emerging Markets.

(and also French) banks would significantly reduce their foreign claims to restore capital ratios (see figure in main text). ${ }^{2 /}$

${ }^{1 /}$ After the third quarter of 2008 U.S. banks aggregate foreign claims rose as a result of the inclusion of new reporters, including in particular the former investment banks.

2/ Based on the methodology of the IMF's Vulnerability Exercise for Advanced Countries (see the companion paper on methodology and theoretical background, Fall 2009). 


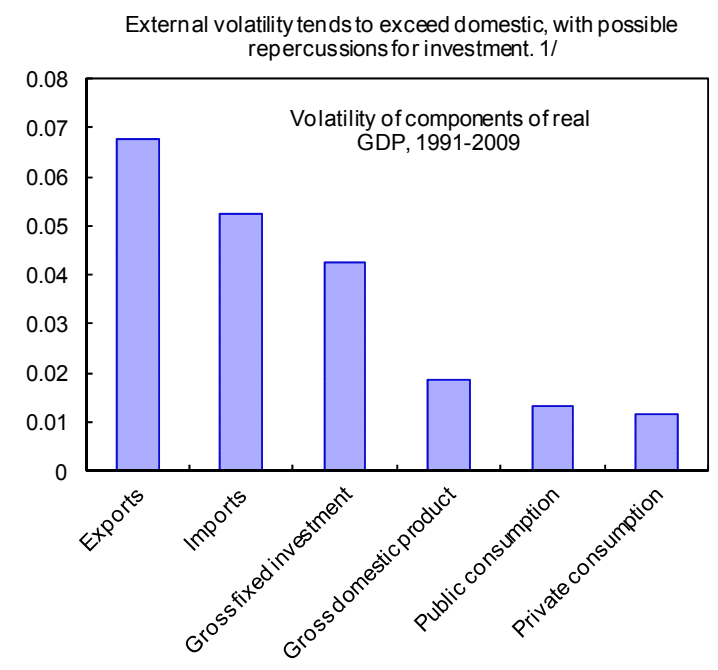

Sources: Authorities and staff estimates.

$1 /$ Volatility is calculated as the standard deviation of annual growth rates around their mean. current account surpluses by increasing imports. To the extent that strengthening domestic sources of growth also reduced the impact of the ups and downs of global demand on economic activity, consumption could increase as well, as households will feel less need to add further to their buffer-stock savings - a link stressed in past Staff Reports. ${ }^{14}$ The authorities agreed in principle but repeated that the scope for the necessary reforms might be limited.

\section{Germany will benefit from such} policies more than less open economies. In highly integrated markets, spillovers work both ways. As a consequence, Germany will

profit more than less open economies from a reduction of global current account imbalances, which will reduce the risk of rapid or excessive exchange rate movements that tend to hurt foreign trade. Similarly, Germany stands to gain from the feedback effects of successful fiscal consolidation. As argued earlier, because Germany often sets the tone for fiscal policy in the EU, it can instill credibility into the SGP framework and help avoid an undesirable macroeconomic policy mix and higherthan-necessary interest rates that would hurt the upswing. Also, ensuring the health of German banks operating across Europe and strengthening financial stability institutions within the developing EU framework will ultimately help to stabilize the recovery in Germany's main markets.

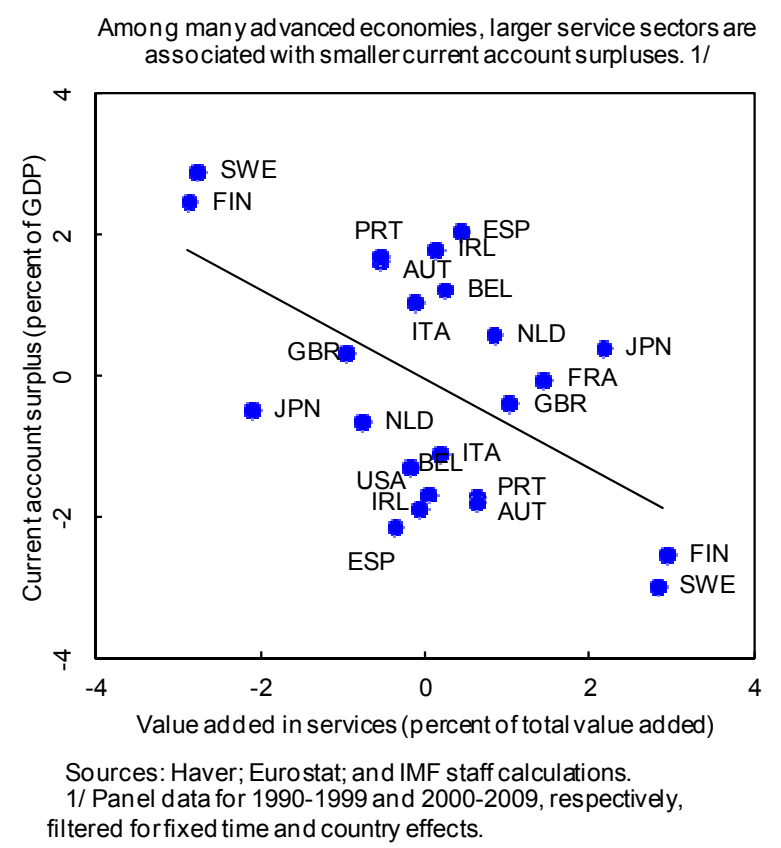

\footnotetext{
${ }^{14}$ See, in particular, Box 1 in IMF, 2009, Germany: 2008 Article IV Consultation: Staff Report, IMF Country Report No. 09/15.
} 


\section{StAFF APPRAISAL}

45. The recovery underway is likely to be moderate, with predominantly downside risks. Muted euro area expansion and the restraint of U.S. consumers will limit Germany's export growth, while domestically consumers will remain cautious given the expected increase in unemployment and moderate income gains, and remaining banking problems will contain credit supply. GDP growth could also be lower because of setbacks to world trade or the domestic financial system.

46. The policy challenge is managing ongoing risks while preparing to unwind the extraordinary measures introduced during the crisis. Fiscal policy will have to transition from supporting the recovery to credible consolidation, financial sector policies from balance sheets repair to improvements of the stability framework, and labor market and structural policies from employment smoothing to fostering domestic growth.

47. Fiscal consolidation needs to start as soon as the recovery has firmed up. The 2010 budget appropriately provides stimulus for a still fragile recovery. As a consequence, the general government deficit is estimated to rise in 2010 to nearly twice the limit set by the SGP. Moreover, the federal structural balance is significantly below the target set by the new constitutional rule for 2016. With public debt rising and private sector growth expected to be self-sustaining by 2011, consolidation should become a priority.

48. Germany's commitment to the SGP and its new constitutional rule is welcomeand has potential benefits for Europe. Meeting these targets would allow Germany to regain fiscal space and prepare for the rising costs of its aging population. Moreover, Germany's actions also matter for Europe because, as in the past, German consolidation could set an example for other countries. This would help avoid an undesirable policy mix of tight monetary and loose fiscal policy in the euro area.

49. Meeting the consolidation targets is a formidable task.

- $\quad$ Fulfilling the government's fiscal targets, including the SGP and the new constitutional rule, will require sizable structural adjustment between 2011 and 2016. Thus, a credible plan, preferably focused on expenditures, is needed fast. In this context, the tensions in the fiscal plans for 2011 should be resolved by designing the planned tax cuts to maximize efficiency and be implemented only with compensating budgetary measures to meet medium-term fiscal objectives.

- $\quad$ Expenditure savings are available including from a systematic examination of subsidies and in the health care system. Agreed-upon adjustment mechanisms for pension benefits and the gradual rise in the retirement age need to be implemented. 
- $\quad$ Should revenue measures have to be part of the solution, eliminating exemptions in income and VAT taxes should have priority before higher VAT rates. A reform of the property tax could support local public finances. Higher unemployment insurance contribution rates would remove the need for repeated government support

50. The health of the financial sector has improved, but time is running short for dealing with the remaining problems and risks, in particular in the ailing Landesbanken sector. Strengthening capital buffers should be a priority for most banks. Despite initial steps towards restructuring, much more needs to be done to prevent the Landesbanken from being a continuous drain on the public finances and source of financial instability. Major consolidation into one wholesale bank for the Sparkassen is a priority, and remaining institutions should have to prove their structural profitability under an alternative ownership structure. Enhanced surveillance of the German banking sector would profit from more comprehensive and timely data and transparent reporting.

\section{The government's commitment to make the Bundesbank the sole prudential} bank supervisor is welcome. The reform would improve the accountability and enforcement of banking supervision. Moreover, choosing the Bundesbank as single agency for macroprudential oversight and monitoring systemic risk will provide for the necessary capability and incentives to identify and address systemic risks - in particular if prudential insurance supervision was added to its portfolio. Either way, effective supervision will require that the resulting institution be both accountable and operationally independent. The transition risks stemming from the reform need to be managed to avoid supervisory lapses.

52. There is a need for a strong and effective bank resolution regime. Against the background of the ongoing discussion at the European level, the authorities have started to develop a legal framework for orderly resolving systemically important banks. Any such regime should include among its tools bridge banks, transactions involving the assumption of liabilities, and the purchase of assets. It will also be important to develop a similar solution for non-systemic banks. The new regime should be in place before the temporary resolution framework provided by SoFFin expires by year-end. If necessary, SoFFin's powers should be extended until the permanent solution is in place.

53. The crisis also highlighted the need to overcome the well-known limitations of Germany's fragmented deposit insurance system. The EU-initiated increase of deposit insurance coverage to $€ 100,000$ next year will be an opportunity to create a unified deposit insurance fund spanning the entire banking system. This would introduce welcome transparency and legal certainty, avoid procyclical after-the-fact contributions, and introduce coverage that can be maintained without public support even in a crisis.

\section{Extraordinary support should be withdrawn also in the structural area. Short-} term crisis policies in the labor market and state aid have helped to preserve employment in the recession, but they could impede long-run growth if continued well into the recovery. 
The government's intention to change the conditions of the Kurzarbeit scheme in line with the recovery is as necessary as it is welcome in this regard.

55. Additional reforms can help Germany's adjustment to the post-crisis worldand contribute to reducing global imbalances. Reduced potential growth and the threat of lower export growth raise the importance of further improving the flexibility of domestic markets. Lower legal and labor-court-based employment protection would facilitate reallocation of workers, while simultaneously improving product market competition and service sector development would foster labor demand. These reforms, through strengthening domestic sources of growth, would not only benefit Germany but could also help rebalancing euro area and global trade.

56. It is proposed that the next Article IV consultation be held on the standard 12-month cycle. 
Table 1. Germany: Selected Economic Indicators

Total area

Total population (2008)

GDP per capita (2008)
357,041 square kilometers

82.2 million

US\$ $44,728.51$

\begin{tabular}{|c|c|c|c|c|c|c|c|}
\hline & 2005 & 2006 & 2007 & 2008 & 2009 & $20101 /$ & $20111 /$ \\
\hline & \multicolumn{7}{|c|}{ (Percentage change) } \\
\hline \multicolumn{8}{|l|}{ Demand and supply } \\
\hline Private consumption & 0.3 & 1.3 & -0.3 & 0.4 & 0.2 & -1.1 & 0.7 \\
\hline Public consumption & 0.4 & 1.0 & 1.7 & 2.0 & 3.0 & 0.9 & 0.9 \\
\hline Gross fixed investment & 0.9 & 7.8 & 5.0 & 3.1 & -9.0 & 3.0 & 3.2 \\
\hline Construction & -3.0 & 4.6 & 0.0 & 2.6 & -0.8 & 3.2 & 3.2 \\
\hline Machinery and equipment & 5.4 & 11.8 & 11.0 & 3.3 & -20.5 & 2.1 & 3.3 \\
\hline Final domestic demand & 0.4 & 2.5 & 1.2 & 1.3 & -1.2 & 0.2 & 1.3 \\
\hline Inventory accumulation 2/ & -0.4 & -0.2 & -0.1 & 0.1 & -0.3 & -0.9 & 0.0 \\
\hline Total domestic demand & 0.0 & 2.2 & 1.0 & 1.7 & -1.6 & -0.8 & 1.3 \\
\hline \multicolumn{8}{|l|}{ Exports of goods and } \\
\hline nonfactor services & 7.7 & 12.9 & 7.5 & 2.9 & -14.2 & 4.4 & 2.2 \\
\hline \multicolumn{8}{|l|}{ Imports of goods and } \\
\hline nonfactor services & 6.6 & 11.9 & 4.8 & 4.3 & -8.7 & 0.2 & 1.3 \\
\hline Foreign balance $2 /$ & 0.7 & 1.1 & 1.5 & -0.3 & -3.4 & 1.9 & 0.5 \\
\hline GDP & 0.7 & 3.2 & 2.5 & 1.2 & -4.9 & 1.2 & 1.7 \\
\hline \multirow[t]{2}{*}{ Output gap (In percent of potential GDP) } & -2.3 & -0.4 & 0.9 & 1.0 & -4.2 & -3.5 & -2.6 \\
\hline & \multicolumn{7}{|c|}{ (In millions of persons, unless otherwise indicated) } \\
\hline \multicolumn{8}{|l|}{ Employment and unemployment } \\
\hline Labor force & 43.3 & 43.2 & 43.3 & 43.4 & 43.3 & 43.2 & 43.2 \\
\hline Employment & 38.7 & 39.0 & 39.7 & 40.2 & 40.1 & 39.5 & 39.2 \\
\hline Unemployment $3 /$ & 4.6 & 4.2 & 3.6 & 3.1 & 3.2 & 3.7 & 4.0 \\
\hline Unemployment rate (in percent) $4 /$ & 9.1 & 8.1 & 8.3 & 7.2 & 7.4 & 8.6 & 9.3 \\
\hline & \multicolumn{7}{|c|}{ (Percentage change) } \\
\hline \multicolumn{8}{|l|}{ Prices and incomes } \\
\hline GDP deflator & 0.7 & 0.5 & 1.9 & 1.5 & 1.4 & 0.5 & 1.0 \\
\hline Consumer price index (harmonized) & 1.9 & 1.8 & 2.3 & 2.8 & 0.2 & 0.9 & 1.0 \\
\hline Average hourly earnings (total economy) & 1.0 & 1.1 & 1.4 & 2.3 & 2.9 & -1.0 & 1.5 \\
\hline Unit labor cost (industry) & -2.9 & -3.5 & -0.4 & 2.8 & 14.1 & -4.0 & 0.2 \\
\hline Real disposable income 5/ & 0.4 & 1.3 & -0.1 & 0.9 & 1.9 & -0.1 & 1.6 \\
\hline Personal saving ratio (in percent) & 10.5 & 10.5 & 10.8 & 11.2 & 12.7 & 13.5 & 14.3 \\
\hline
\end{tabular}

Sources: Deutsche Bundesbank; Federal Statistical Office; IMF staff estimates and projections.

$1 /$ IMF staff estimates and projections.

2/ Growth contribution.

3/ National accounts definition.

4/ Eurostat definition.

5/ Deflated by the national accounts deflator for private consumption. 
Table 1. Germany: Selected Economic Indicators (concluded)

\begin{tabular}{|c|c|c|c|c|c|c|c|}
\hline & 2005 & 2006 & 2007 & 2008 & $20091 /$ & $20101 /$ & $20111 /$ \\
\hline & \multicolumn{7}{|c|}{ (In billions of euros, unless otherwise indicated) } \\
\hline \multicolumn{8}{|l|}{ Public finances } \\
\hline \multicolumn{8}{|l|}{ General government } \\
\hline Expenditure & 1,050 & 1,055 & 1,061 & 1,090 & 1,146 & 1,177 & 1,174 \\
\hline (In percent of GDP) & 46.8 & 45.4 & 43.7 & 43.7 & 47.7 & 48.1 & 46.7 \\
\hline Revenue & 976 & 1,016 & 1,066 & 1,091 & 1,067 & 1,037 & 1,045 \\
\hline (In percent of GDP) & 43.5 & 43.7 & 43.9 & 43.7 & 44.4 & 42.4 & 41.6 \\
\hline Overall balance & -74 & -38 & 5 & 1 & -79 & -139 & -129 \\
\hline (In percent of GDP) & -3.3 & -1.6 & 0.2 & 0.0 & -3.3 & -5.7 & -5.1 \\
\hline Structural balance & -50 & -33 & -1 & -11 & -27 & -95 & -95 \\
\hline (In percent of GDP) & -2.2 & -1.4 & 0.0 & -0.4 & -1.1 & -3.9 & -3.8 \\
\hline \multicolumn{8}{|l|}{ Federal government } \\
\hline Overall balance 6/ & -47 & -35 & -19 & -14 & -40 & -85 & -73 \\
\hline (In percent of GDP) & -2.1 & -1.5 & -0.8 & -0.6 & -1.7 & -3.5 & -2.9 \\
\hline General government debt & 1,524 & 1,571 & 1,578 & 1,644 & 1,744 & 1,875 & 1,998 \\
\hline (In percent of GDP) & 68.0 & 67.6 & 65.0 & 65.9 & 72.5 & 76.7 & 79.5 \\
\hline \multicolumn{8}{|l|}{ Balance of payments } \\
\hline Trade balance $7 /$ & 144.4 & 146.3 & 185.9 & 178.3 & 124.5 & 167.8 & 1548.6 \\
\hline Services balance & -25.7 & -14.0 & -13.3 & -12.7 & 0.0 & 3.4 & 6.1 \\
\hline Factor income balance & 25.7 & 37.6 & 42.0 & 39.7 & 25.5 & -1.3 & -14.1 \\
\hline Net private transfers & -17.6 & -14.5 & -16.3 & -16.8 & -17.3 & -20.9 & -24.6 \\
\hline Net official transfers & -11.1 & -12.6 & -15.3 & -16.3 & -17.3 & -17.1 & -17.8 \\
\hline Current account & 115.4 & 142.4 & 182.6 & 160.2 & 115.5 & 132.0 & 138.2 \\
\hline (In percent of GDP) & 5.1 & 6.1 & 7.5 & 6.4 & 4.8 & 5.4 & 5.5 \\
\hline Foreign exchange reserves (e. o. p.) 8/ & 33.7 & 28.6 & 27.7 & 27.7 & 26.0 & 27.1 & $\ldots$ \\
\hline & \multicolumn{7}{|c|}{ (Percentage change) } \\
\hline \multicolumn{8}{|l|}{ Monetary data } \\
\hline Money and quasi-money (M3) 9/ 10/ & 5.2 & 4.9 & 10.7 & 9.6 & -1.2 & $\ldots$ & $\ldots$ \\
\hline Credit to private sector $9 /$ & 2.1 & 3.5 & 3.2 & 6.5 & -0.7 & $\ldots$ & $\ldots$ \\
\hline & \multicolumn{7}{|c|}{ (Period average in percent) } \\
\hline \multicolumn{8}{|l|}{ Interest rates } \\
\hline Three-month interbank rate $11 /$ & 2.1 & 3.7 & 4.8 & 3.4 & 0.7 & $\ldots$ & $\ldots$ \\
\hline Yield on ten-year government bonds $11 /$ & 3.6 & 3.8 & 4.3 & 3.2 & 3.2 & $\ldots$ & $\ldots$ \\
\hline \multicolumn{8}{|l|}{ Exchange rates } \\
\hline Euro per US\$ (annual average) 12/ & 0.80 & 0.80 & 0.73 & 0.73 & 0.68 & 0.70 & $\ldots$ \\
\hline Nominal effective rate $(1990=100) 12 /$ & 114.7 & 114.9 & 119.7 & 120.7 & 122.2 & 120.8 & $\ldots$ \\
\hline Real effective rate $(1990=100) 13 /$ & 103.2 & 100.2 & 97.3 & 92.6 & 91.7 & 90.7 & $\ldots$ \\
\hline
\end{tabular}

6/ The federal government's budget balance in 2010 would improve by $1 / 2$ percentage point of GDP if the support to the federal employment agency were not a grant but a loan.

7/ Including supplementary trade items.

8/ Data for 2010 refer to January.

9/ Data for 2009 refer to the change to December

10/ Data reflect Germany's contribution to M3 of the euro area.

11/ Data for 2009 refer to December.

12/ Data for 2010 refer to January.

13/ Based on relative normalized unit labor cost in manufacturing. Data for 2010 refer to January. 
Table 2. Germany: Foreign Claims of Banks on Individual Countries, December 31, 2009 1/

(In billions of U.S. dollars; unless otherwise specified)

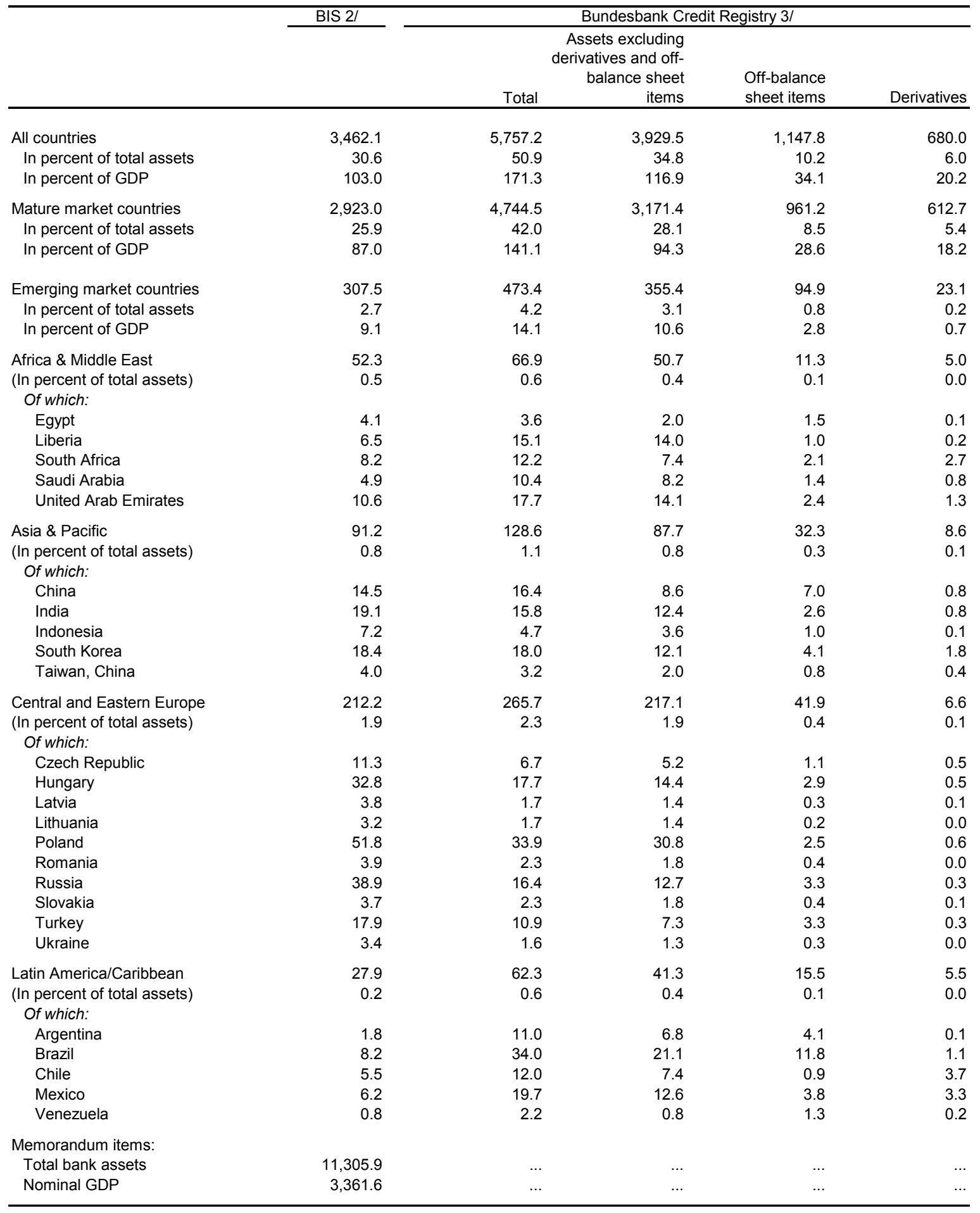

Sources: BIS; Deutsche Bundesbank; ECB; and IMF staff estimates.

$1 /$ Foreign claims include all international claims plus local claims of foreign affiliates in local currency. The difference between the claims to all countries and the sum of mature and emerging market exposures is due to offshore center exposures.

2/ BIS data is based on the consolidated lending statistic compiled by the Bundesbank (as of 2009:Q2).

3/ The data are derived from the "Groß- und Millionenkreditmeldung" stipulated in $\S \S 13$ and 14 KWG (Credit Services Act). Under the Credit Services Act, debtors are obliged to register all loans (and other credit-like obligations) of $€ 1.5$ million or higher with the Bundesbank on a quarterly basis. In this context, the definition of credit also included equity and counterparty risk exposure from credit default swaps (CDS). Specific details on the obligation to register are stipulated in the Groß- und Millionenkreditverordnung (GroMikV). Credit derivative exposures are recorded as off-shore transactions at their nominal value if available, otherwise the book value applies.

The presented data reflect gross amounts without recognition of collateral. 
Table 3. Germany: The Core Set of Financial Soundness Indicators for Banks, 1999-2008 $1 /$

(In percent)

\begin{tabular}{|c|c|c|c|c|c|c|c|c|c|c|}
\hline & 1999 & 2000 & 2001 & 2002 & 2003 & 2004 & 2005 & 2006 & 2007 & 2008 \\
\hline \multicolumn{11}{|l|}{ Capital adequacy } \\
\hline Regulatory capital to risk-weighted assets & 10.8 & 10.9 & 11.2 & 11.9 & 12.4 & 12.4 & 12.2 & 12.5 & 12.9 & 13.6 \\
\hline Commercial banks & 10.9 & 11.3 & 12.0 & 12.7 & 12.8 & 12.5 & 11.6 & 12.5 & 13.3 & 13.5 \\
\hline Landesbanken & 9.9 & 10.0 & 10.4 & 11.5 & 13.0 & 12.2 & 12.1 & 11.7 & 11.6 & 12.7 \\
\hline Savings banks & 10.8 & 10.6 & 10.7 & 11.1 & 11.4 & 12.0 & 12.5 & 13.0 & 13.0 & 14.4 \\
\hline Credit cooperatives & 11.1 & 11.0 & 10.9 & 10.9 & 11.6 & 12.0 & 12.1 & 12.2 & 12.9 & 14.2 \\
\hline Regulatory Tier I capital to risk-weighted assets $2 /$ & 6.9 & 7.0 & 7.2 & 7.8 & 8.2 & 8.0 & 8.0 & 8.2 & 8.5 & 9.5 \\
\hline Commercial banks & 7.3 & 7.6 & 8.2 & 8.7 & 9.0 & 8.3 & 7.9 & 8.4 & 10.6 & 10.3 \\
\hline Landesbanken & 5.6 & 5.5 & 5.8 & 7.0 & 7.8 & 7.1 & 7.3 & 7.1 & 7.1 & 8.3 \\
\hline Savings banks & 7.0 & 6.9 & 7.0 & 7.2 & 7.4 & 7.7 & 8.0 & 8.4 & 8.4 & 9.5 \\
\hline Credit cooperatives & 7.2 & 7.3 & 7.3 & 7.5 & 8.0 & 8.3 & 8.5 & 9.1 & 8.7 & 9.7 \\
\hline \multicolumn{11}{|l|}{ Asset composition and quality } \\
\hline \multicolumn{11}{|l|}{ Sectoral distribution of loans to total loans } \\
\hline Loan to households & 31.2 & 30.6 & 29.7 & 29.5 & 29.7 & 29.3 & 28.5 & 27.6 & 25.6 & 24.4 \\
\hline Commercial banks & 31.0 & 29.2 & 27.5 & 26.8 & 26.1 & 25.8 & 24.8 & 23.9 & 21.8 & 20.5 \\
\hline Landesbanken & 8.3 & 8.2 & 7.9 & 7.5 & 7.5 & 7.1 & 6.8 & 6.2 & 5.2 & 4.9 \\
\hline Savings banks & 63.8 & 63.6 & 62.4 & 61.9 & 62.9 & 62.3 & 62.2 & 61.1 & 58.2 & 56.4 \\
\hline Credit cooperatives & 66.6 & 68.0 & 66.4 & 67.0 & 68.1 & 68.3 & 69.3 & 68.5 & 66.3 & 63.5 \\
\hline Loans to non-financial corporations & 17.3 & 17.4 & 17.1 & 16.6 & 16.0 & 15.2 & 14.5 & 14.3 & 14.1 & 14.5 \\
\hline Commercial banks & 22.3 & 20.7 & 19.3 & 17.7 & 15.6 & 14.3 & 13.3 & 12.6 & 12.4 & 12.6 \\
\hline Landesbanken & 18.9 & 19.5 & 19.7 & 18.9 & 18.5 & 17.8 & 16.7 & 17.0 & 16.2 & 17.8 \\
\hline Savings banks & 17.7 & 18.5 & 18.8 & 18.6 & 18.3 & 18.0 & 17.6 & 17.3 & 17.6 & 18.7 \\
\hline Credit cooperatives & 13.0 & 13.6 & 13.4 & 13.2 & 12.9 & 12.4 & 12.0 & 12.1 & 12.4 & 12.7 \\
\hline NPLs to gross loans & 4.1 & 4.6 & 4.5 & 5.0 & 5.2 & 4.9 & 4.0 & 3.4 & 2.6 & 2.8 \\
\hline Commercial banks & 5.0 & 5.7 & 5.2 & 5.2 & 5.1 & 4.5 & 3.3 & 2.6 & 1.8 & 2 \\
\hline Landesbanken & 2.5 & 2.7 & 2.8 & 3.7 & 4.4 & 4.1 & 2.9 & 2.0 & 1.5 & 2.4 \\
\hline Savings banks & 5.7 & 5.6 & 5.9 & 6.4 & 6.8 & 6.9 & 6.6 & 5.9 & 5.1 & 4.7 \\
\hline Credit cooperatives & 6.4 & 6.9 & 7.2 & 8.0 & 8.1 & 8.2 & 7.3 & 6.6 & 5.5 & 5.1 \\
\hline NPLs net of provisions to capital & 38.6 & 44.0 & 45.4 & 47.8 & 50.4 & 44.5 & 34.6 & 28.6 & 21.6 & 25.3 \\
\hline Commercial banks & 38.5 & 40.7 & 51.2 & 47.2 & 54.5 & 41.2 & 30.6 & 24.6 & 15.8 & 20.1 \\
\hline Landesbanken 3/ & 26.0 & 29.6 & 27.9 & 31.6 & 34.9 & 37.4 & 25.0 & $16.14 /$ & 11.3 & 27.6 \\
\hline Savings banks & 51.6 & 49.2 & 52.1 & 53.6 & 58.0 & 54.2 & 50.4 & 43.6 & 35.3 & 33 \\
\hline Credit cooperatives & 49.7 & 51.9 & 53.5 & 61.0 & 58.3 & 57.2 & 49.0 & 43.0 & 35.9 & 33.3 \\
\hline \multicolumn{11}{|l|}{ Earnings and profitability } \\
\hline Return on average assets (after-tax) & 0.2 & 0.2 & 0.2 & 0.1 & -0.1 & 0.1 & 0.3 & 0.3 & 0.2 & -0.3 \\
\hline Commercial banks & 0.3 & 0.3 & 0.2 & 0.0 & -0.3 & -0.1 & 0.5 & 0.3 & 0.5 & -0.5 \\
\hline Landesbanken & 0.1 & 0.1 & 0.1 & 0.1 & -0.2 & 0.0 & 0.2 & 0.3 & 0.0 & -0.4 \\
\hline Savings banks & 0.2 & 0.3 & 0.2 & 0.2 & 0.2 & 0.2 & 0.3 & 0.2 & 0.2 & 0.1 \\
\hline Credit cooperatives & 0.2 & 0.2 & 0.2 & 0.3 & 0.3 & 0.3 & 0.5 & 0.5 & 0.3 & 0.2 \\
\hline Return on average equity (after-tax) & 6.5 & 6.1 & 4.6 & 2.9 & -1.5 & 1.9 & 9.2 & 7.5 & 4.7 & -8.1 \\
\hline Commercial banks & 7.0 & 7.3 & 4.2 & 0.0 & -6.6 & -1.4 & 15.5 & 9.1 & 15.6 & -15.1 \\
\hline Landesbanken & 5.9 & 4.2 & 4.0 & 1.9 & -5.2 & -0.8 & 5.6 & 9.7 & 0.9 & -12.2 \\
\hline Savings banks & 6.1 & 6.1 & 5.1 & 4.7 & 4.0 & 5.0 & 5.6 & 5.0 & 4.2 & 2.2 \\
\hline Credit cooperatives & 4.7 & 4.1 & 4.4 & 6.6 & 5.2 & 5.3 & 9.0 & 8.5 & 5.2 & 4.0 \\
\hline Interest margin to gross income & 73.2 & 67.8 & 69.8 & 73.4 & 70.2 & 73.5 & 68.2 & 68.2 & 72.9 & 84.6 \\
\hline Commercial banks & 61.7 & 52.7 & 56.2 & 63.7 & 56.5 & 64.9 & 55.3 & 61.8 & 66.3 & 94.6 \\
\hline Landesbanken & 77.6 & 72.4 & 75.0 & 75.8 & 79.0 & 79.4 & 83.2 & 70.3 & 91.6 & 90.2 \\
\hline Savings banks & 81.3 & 80.9 & 80.8 & 81.3 & 80.6 & 79.6 & 79.0 & 77.7 & 75.2 & 76.0 \\
\hline Credit cooperatives & 77.1 & 76.5 & 78.3 & 79.1 & 75.4 & 75.5 & 74.7 & 65.3 & 71.3 & 69.9 \\
\hline Noninterest expenses to gross income & 66.0 & 68.4 & 71.4 & 67.2 & 66.5 & 65.5 & 61.0 & 62.3 & 64.9 & 73.4 \\
\hline Commercial banks & 73.9 & 75.4 & 80.4 & 74.2 & 74.0 & 73.5 & 59.8 & 66.0 & 65.5 & 93.7 \\
\hline Landesbanken & 54.8 & 55.9 & 57.1 & 56.1 & 53.1 & 53.5 & 59.3 & 53.6 & 61.1 & 54.6 \\
\hline Savings banks & 65.7 & 68.9 & 69.9 & 66.5 & 66.4 & 64.9 & 66.0 & 65.8 & 69.5 & 68.7 \\
\hline Credit cooperatives & 71.2 & 74.5 & 76.7 & 73.1 & 69.6 & 68.7 & 70.0 & 64.3 & 70.5 & 68.3 \\
\hline \multicolumn{11}{|l|}{ Liquidity } \\
\hline Liquid assets to total short-term liabilities 3 / & $\ldots$ & 120.9 & 121.1 & 121.0 & 123.5 & 124.4 & 122.0 & 120.9 & 119.4 & 120.3 \\
\hline Commercial banks & $\ldots$ & 109.0 & 111.0 & 110.9 & 111.7 & 110.2 & 110.7 & 111.8 & 113.0 & 114.8 \\
\hline Landesbanken & $\ldots$ & 110.2 & 104.0 & 107.1 & 115.5 & 129.9 & 122.4 & 118.8 & 115.5 & 114.5 \\
\hline Savings banks & $\ldots$ & 202.5 & 212.6 & 211.6 & 207.8 & 221.6 & 224.2 & 206.9 & 190.9 & 161.8 \\
\hline Credit cooperatives & $\ldots$ & 178.8 & 184.0 & 193.4 & 189.6 & 193.4 & 181.4 & 174.8 & 167.1 & 146.1 \\
\hline \multicolumn{11}{|l|}{ Sensitivity to market risk } \\
\hline Net open positions in FX to capital & 11.3 & 11.0 & 10.7 & 11.4 & 6.7 & 6.9 & 6.9 & 6.7 & 6.9 & 6.6 \\
\hline Commercial banks & 11.9 & 7.3 & 7.2 & 5.2 & 6.1 & 4.4 & 5.7 & 10.1 & 6.2 & 4.5 \\
\hline Landesbanken & 10.1 & 11.7 & 11.6 & 14.7 & 4.6 & 6.7 & 5.6 & 4.2 & 6.6 & 5.2 \\
\hline Savings banks & 11.9 & 13.6 & 14.3 & 13.8 & 12.2 & 11.1 & 11.7 & 10.1 & 10.9 & 12.2 \\
\hline Credit cooperatives & 19.7 & 21.8 & 21.7 & 20.8 & 16.1 & 15.6 & 14.0 & 11.3 & 10.7 & 8.2 \\
\hline
\end{tabular}

Source: Deutsche Bundesbank. The authorities provide annual data only and disseminate them once a year.

$1 /$ A methodological break in the supervisory time series on the capital adequacy of German banks has taken place in 2007 due to substantial changes in the regulatory reporting framework, following Basel II.

2/ 1998-2006 according to Capital Adequacy Regulation, Principle I. Since 2007 according to Solvency Regulation.

3/ 2000-2008 data compiled in accordance with IMF's FSI Compilation Guide. Data not available before July 1, 2000.

4/ Due to one off data availability, comparability of 2006 data with other years limited. 
Table 4. Germany: Encouraged and Other Financial Soundness Indicators, 1999-2008 (In percent, unless otherwise indicated)

\begin{tabular}{|c|c|c|c|c|c|c|c|c|c|c|}
\hline & 1999 & 2000 & 2001 & 2002 & 2003 & 2004 & 2005 & 2006 & 2007 & 2008 \\
\hline \multicolumn{11}{|l|}{ Corporate sector } \\
\hline Total debt to equity $1 /$ & 82.8 & 99.8 & 108.2 & 159.8 & 138.5 & 127.4 & 116.7 & 109.2 & 102.1 & 147.3 \\
\hline Total debt to GDP 2/ & 148.7 & 163.6 & 166.0 & 172.5 & 172.6 & 162.3 & 160.8 & 162.7 & 164.0 & 169.0 \\
\hline Return on invested capital 3/ 4/ & 6.4 & 6.3 & 7.3 & 8.5 & 8.0 & 8.6 & 8.9 & 8.7 & 8.7 & 10.1 \\
\hline Earnings to interest and principal expenses $1 / 5 /$ & 561.9 & 495.6 & 513.8 & 536.9 & 570.8 & 715.3 & 743.3 & 778.2 & 767.5 & 708.4 \\
\hline Number of applications for protection from creditors $1 / 6$ / & 18,006 & 18,389 & 21,019 & 23,642 & 23,840 & 22,474 & 19,540 & 16,408 & 13,599 & 13,358 \\
\hline \multicolumn{11}{|l|}{ Deposit-taking institutions } \\
\hline Capital to assets & 3.7 & 3.7 & 3.8 & 4.1 & 4.2 & 4.0 & 4.1 & 4.3 & 4.3 & 4.5 \\
\hline Commercial banks & 5.0 & 4.7 & 4.9 & 5.2 & 5.0 & 4.4 & 4.4 & 4.4 & 4.3 & 5.0 \\
\hline Landesbanken & 3.3 & 3.4 & 3.8 & 3.8 & 4.0 & 4.0 & 4.0 & 3.8 & 3.7 & 3.8 \\
\hline Savings banks & 3.8 & 3.9 & 4.0 & 4.2 & 4.3 & 4.5 & 4.6 & 4.8 & 4.9 & 5.0 \\
\hline Credit cooperatives & 4.6 & 4.9 & 4.7 & 4.9 & 5.1 & 5.3 & 5.4 & 5.6 & 5.5 & 5.3 \\
\hline \multicolumn{11}{|l|}{ Geographical distribution of loans to total loans } \\
\hline Germany & 85.4 & 83.6 & 81.3 & 80.0 & 78.6 & 76.8 & 75.2 & 72.6 & 71.1 & 71.2 \\
\hline EU-member countries & 8.6 & 9.6 & 11.6 & 13.2 & 14.6 & 16.9 & 17.3 & 19.5 & 20.4 & 20.2 \\
\hline Others & 6.0 & 6.8 & 7.1 & 6.8 & 6.8 & 6.3 & 7.5 & 7.9 & 8.5 & 8.6 \\
\hline FX loans to total loans & 7.8 & 9.3 & 10.2 & 9.6 & 9.1 & 9.6 & 10.2 & 10.5 & 11.5 & 12.2 \\
\hline Personnel expenses to noninterest expenses & 54.8 & 54.1 & 53.1 & 53.1 & 53.8 & 54.4 & 55.1 & 56.4 & 54.7 & 53.3 \\
\hline Commercial banks & 51.3 & 50.4 & 49.2 & 48.5 & 49.4 & 49.7 & 50.7 & 52.5 & 51.7 & 47.5 \\
\hline Landesbanken & 51.0 & 51.9 & 49.8 & 49.6 & 49.0 & 50.2 & 50.5 & 55 & 51.7 & 49.7 \\
\hline Savings banks & 59.9 & 60.0 & 59.3 & 59.5 & 60.6 & 61.3 & 61.8 & 61.5 & 58.5 & 61.1 \\
\hline Credit cooperatives & 58.5 & 57.8 & 58.4 & 59.0 & 59.0 & 59.2 & 60.1 & 60.9 & 59.8 & 61.0 \\
\hline Trading and fee income to total income & 26.8 & 32.2 & 30.2 & 26.6 & 29.8 & 26.5 & 31.8 & 31.8 & 27.1 & 15.4 \\
\hline Commercial banks & 38.3 & 47.3 & 43.8 & 36.3 & 43.5 & 35.1 & 44.7 & 38.2 & 33.7 & 5.4 \\
\hline Landesbanken & 22.4 & 27.6 & 25.0 & 24.2 & 21.0 & 20.6 & 16.8 & 29.7 & 8.4 & 9.8 \\
\hline Savings banks & 18.7 & 19.1 & 19.2 & 18.7 & 19.4 & 20.4 & 21.0 & 22.3 & 24.8 & 24.0 \\
\hline Credit cooperatives & 22.9 & 23.5 & 21.7 & 20.9 & 24.6 & 24.5 & 25.3 & 34.8 & 28.7 & 30.1 \\
\hline Customer deposits to total (non-interbank) loans & 63.5 & 63.9 & 64.0 & 65.4 & 67.1 & 70.0 & 71.8 & 75.2 & 76.2 & 77.7 \\
\hline Commercial banks & 62.6 & 63.0 & 68.6 & 74.2 & 78.4 & 85.3 & 85.5 & 95.7 & 92.6 & 90.7 \\
\hline Landesbanken & 35.2 & 38.4 & 34.3 & 30.1 & 32.8 & 35.4 & 40.6 & 42.9 & 45.7 & 44.1 \\
\hline Savings banks & 104.7 & 101.8 & 101.1 & 100.3 & 99.8 & 101.0 & 102.2 & 103.3 & 105.4 & 108.3 \\
\hline Credit cooperatives & 113.6 & 108.0 & 110.3 & 110.8 & 111.7 & 113.2 & 113.6 & 113.1 & 114.7 & 119.6 \\
\hline Spread between highest and lowest interbank rates $7 /$ & $\ldots$ & $\ldots$ & $\ldots$ & $\ldots$ & $\ldots$ & $\ldots$ & 2.0 & 2.6 & 4.6 & 10.5 \\
\hline Spread between reference loan and deposit rates $8 /$ & $\ldots$ & $\ldots$ & $\ldots$ & $\ldots$ & 379 & 366 & 353 & 317 & 285 & 273 \\
\hline \multicolumn{11}{|l|}{ Insurance sector } \\
\hline Solvency ratio, Life & $\ldots$ & $\ldots$ & 199 & 170 & 176 & 177 & 190 & 203.8 & 206.8 & n.a. \\
\hline Solvency ratio, Non-life & $\ldots$ & 350 & 343 & 337 & 346 & 286 & 255 & 310.7 & 321.6 & n.a. \\
\hline Return on average equity, Life 9/ & 11.4 & 12.5 & 7.0 & 3.4 & 5.7 & 5.8 & 9.7 & 9.5 & 8.8 & n.a. \\
\hline Return on average equity, Non-life 9/ & 7.3 & 8.7 & 8.9 & 2.8 & 4.2 & 3.0 & 4.5 & 4.6 & 4.1 & n.a. \\
\hline \multicolumn{11}{|l|}{ Market liquidity } \\
\hline Average bid-ask spread in the securities market (government bills) & $\ldots$ & $\ldots$ & $\ldots$ & $\ldots$ & $\ldots$ & $\ldots$ & 0.0 & 0.0 & 0.0 & 0.0 \\
\hline Average bid-ask spread in the securities market (corporate securities) & $\ldots$ & $\ldots$ & $\ldots$ & $\ldots$ & $\ldots$ & $\ldots$ & 0.1 & 0.1 & 0.1 & 0.3 \\
\hline \multicolumn{11}{|l|}{ Households } \\
\hline Household debt to GDP 1/ & 72.9 & 73.4 & 72.7 & 72.4 & 72.5 & 71.2 & 70.0 & 67.4 & 63.7 & 61.4 \\
\hline Household debt service and principal payments to income 1/5/ & 4.7 & 5.1 & 5.0 & 4.7 & 4.2 & 3.9 & 3.7 & 3.8 & 4.1 & 4.1 \\
\hline \multicolumn{11}{|l|}{ Real estate markets } \\
\hline Real estate prices, new dwellings $10 /$ & 99 & 100 & 101 & 102 & 100 & 100 & 100 & 101 & 102 & 102.0 \\
\hline Real estate prices, resale $10 /$ & 108 & 108 & 108 & 105 & 104 & 102 & 100 & 100 & 100 & 102.0 \\
\hline Residential real estate loans to total loans & 16.2 & 16.4 & 16.1 & 16.2 & 18.0 & 17.8 & 17.8 & 17.7 & 16.5 & 15.7 \\
\hline Commercial real estate loans to total loans & 6.4 & 6.4 & 6.2 & 6.2 & 6.6 & 6.4 & 6.1 & 5.8 & 5.4 & 5.2 \\
\hline
\end{tabular}

Source: Deutsche Bundesbank. The authorities provide annual data only and disseminate them once a year.

$1 /$ Indicator compiled according to definitions of the Compilation Guide on FSIs.

2/ Total debt to corporate gross value added.

3/ Return defined as net operating income less taxes, where net operating income and taxes are compiled according to the FSI Compilation Guide.

4/ Invested capital estimated as balance sheet total less other accounts payable (AF.7 according to ESA 1995).

5/ Excluding principal payments.

6/ Resident enterprises that filed for bankruptcy.

7/ Spread between highest and lowest three month money market rates as reported by Frankfurt banks (basis points).

8/ Spread in basis points.

9/ Profits after tax devided by equity.

10/ Residential property index (yearly average, $2005=100$ ); aggregation of data for new dwellings and resale is not available. 
Table 5. Germany: Medium-Term Balance of Payments, 2007-15

\begin{tabular}{|c|c|c|c|c|c|c|c|c|c|}
\hline & 2007 & 2008 & 2009 & 2010 & 2011 & 2012 & 2013 & 2014 & 2015 \\
\hline & & & Est. & \multicolumn{6}{|c|}{ Projections } \\
\hline & \multicolumn{9}{|c|}{ (In billions of euros, unless otherwise indicated) } \\
\hline Current account & 183 & 160 & 115 & 132 & 138 & 133 & 127 & 121 & 113 \\
\hline In percent of GDP & 7.5 & 6.4 & 4.8 & 5.4 & 5.5 & 5.1 & 4.7 & 4.4 & 4.0 \\
\hline Trade balance & 186 & 178 & 122 & 162 & 183 & 193 & 203 & 218 & 232 \\
\hline Exports & 984 & 984 & 796 & 832 & 856 & 880 & 910 & 947 & 985 \\
\hline Imports & -798 & -806 & -674 & -670 & -673 & -687 & -707 & -729 & -753 \\
\hline Nonfactor services & -13 & -13 & 2 & 9 & 12 & 15 & 17 & 19 & 21 \\
\hline Exports & 164 & 170 & 167 & 169 & 172 & 178 & 185 & 192 & 199 \\
\hline Imports & -178 & -183 & -165 & -159 & -160 & -163 & -168 & -173 & -179 \\
\hline Balance on factor income & 51 & 45 & 26 & -1 & -14 & -28 & -41 & -58 & -74 \\
\hline Credit & 239 & 245 & 202 & 181 & 193 & 222 & 244 & 244 & 245 \\
\hline Debit & -188 & -200 & -176 & -182 & -207 & -250 & -285 & -302 & -320 \\
\hline Current transfers, net & -32 & -33 & -35 & -38 & -42 & -47 & -53 & -59 & -65 \\
\hline Capital and financial accounts & -237 & -206 & -115 & -132 & -138 & -133 & -127 & -121 & -113 \\
\hline Capital account, net & 0 & 0 & 0 & 0 & 0 & 0 & 0 & 0 & 0 \\
\hline FDI, net & -90 & -92 & -65 & -62 & -66 & -69 & -71 & -73 & -75 \\
\hline Portfolio investment, net & 66 & 18 & 18 & 18 & 18 & 19 & 20 & 20 & 21 \\
\hline Other & -213 & -130 & -68 & -88 & -91 & -84 & -76 & -68 & -59 \\
\hline Reserve assets & -1 & -2 & 0 & 0 & 0 & 0 & 0 & 0 & 0 \\
\hline Errors and omissions & 54 & 46 & 0 & 0 & 0 & 0 & 0 & 0 & 0 \\
\hline
\end{tabular}

Sources: Deutsche Bundesbank; Federal Statistical Office; IMF, World Economic Outlook; and staff. 
Table 6. General Government Operations

\begin{tabular}{|c|c|c|c|c|c|c|c|c|c|c|}
\hline & 2007 & 2008 & 2009 & 2010 & 2011 & 2012 & 2013 & 2014 & 2015 & 2016 \\
\hline & & & Est. & \multicolumn{7}{|c|}{ Projections } \\
\hline & \multicolumn{10}{|c|}{ (In billions of euros) } \\
\hline Revenue & 1,066 & 1,091 & 1,067 & 1,037 & 1,045 & 1,099 & 1,141 & 1,182 & 1,221 & 1,266 \\
\hline Taxes & 576 & 593 & 566 & 547 & 551 & 586 & 610 & 634 & 653 & 677 \\
\hline Indirect taxes & 305 & 313 & 297 & 293 & 306 & 327 & 340 & 352 & 364 & 378 \\
\hline Direct taxes & 271 & 281 & 269 & 254 & 245 & 259 & 271 & 282 & 289 & 299 \\
\hline Social contributions & 400 & 408 & 411 & 405 & 407 & 422 & 441 & 456 & 473 & 490 \\
\hline Grants & 11 & 10 & 10 & 10 & 10 & 11 & 11 & 11 & 12 & 12 \\
\hline Other current revenue & 79 & 80 & 80 & 76 & 77 & 80 & 80 & 82 & 84 & 87 \\
\hline Expense & 1,042 & 1,056 & 1,101 & 1,126 & 1,146 & 1,174 & 1,194 & 1,216 & 1,241 & 1,270 \\
\hline Compensation of employees & 168 & 171 & 177 & 182 & 182 & 186 & 188 & 194 & 200 & 205 \\
\hline Goods and services & 102 & 107 & 106 & 108 & 108 & 111 & 110 & 113 & 116 & 119 \\
\hline Interest & 67 & 69 & 65 & 63 & 65 & 80 & 82 & 78 & 78 & 78 \\
\hline Subsidies & 27 & 27 & 33 & 32 & 32 & 29 & 27 & 28 & 29 & 30 \\
\hline Social benefits & 597 & 607 & 641 & 659 & 675 & 681 & 697 & 711 & 723 & 739 \\
\hline Other expense & 81 & 74 & 79 & 81 & 84 & 86 & 89 & 92 & 94 & 99 \\
\hline Gross operating balance & 24 & 35 & -34 & -89 & -100 & -75 & -52 & -34 & -19 & -4 \\
\hline Net acquisition of nonfinancial assets & 19 & 34 & 45 & 51 & 28 & 29 & 28 & 29 & 30 & 31 \\
\hline \multirow[t]{2}{*}{ Net lending / borrowing } & 5 & 1 & -79 & -139 & -129 & -104 & -81 & -63 & -49 & -35 \\
\hline & \multicolumn{10}{|c|}{ (In percent of GDP) } \\
\hline Revenue & 43.9 & 43.7 & 44.4 & 42.4 & 41.6 & 42.4 & 42.8 & 43.0 & 43.2 & 43.4 \\
\hline Taxes & 23.7 & 23.8 & 23.5 & 22.4 & 21.9 & 22.6 & 22.9 & 23.1 & 23.1 & 23.2 \\
\hline Indirect taxes & 12.6 & 12.5 & 12.3 & 12.0 & 12.2 & 12.6 & 12.7 & 12.8 & 12.9 & 13.0 \\
\hline Direct taxes & 11.2 & 11.2 & 11.2 & 10.4 & 9.7 & 10.0 & 10.1 & 10.2 & 10.2 & 10.2 \\
\hline Social contributions & 16.5 & 16.3 & 17.1 & 16.6 & 16.2 & 16.3 & 16.5 & 16.6 & 16.7 & 16.8 \\
\hline Grants & 0.4 & 0.4 & 0.4 & 0.4 & 0.4 & 0.4 & 0.4 & 0.4 & 0.4 & 0.4 \\
\hline Other current revenue & 3.2 & 3.2 & 3.3 & 3.1 & 3.1 & 3.1 & 3.0 & 3.0 & 3.0 & 3.0 \\
\hline Expense & 42.9 & 42.3 & 45.8 & 46.1 & 45.6 & 45.3 & 44.7 & 44.3 & 43.9 & 43.5 \\
\hline Compensation of employees & 6.9 & 6.9 & 7.4 & 7.4 & 7.2 & 7.2 & 7.1 & 7.1 & 7.1 & 7.0 \\
\hline Goods and services & 4.2 & 4.3 & 4.4 & 4.4 & 4.3 & 4.3 & 4.1 & 4.1 & 4.1 & 4.1 \\
\hline Interest & 2.8 & 2.8 & 2.7 & 2.6 & 2.6 & 3.1 & 3.1 & 2.9 & 2.8 & 2.7 \\
\hline Subsidies & 1.1 & 1.1 & 1.4 & 1.3 & 1.3 & 1.1 & 1.0 & 1.0 & 1.0 & 1.0 \\
\hline Social benefits & 24.6 & 24.3 & 26.6 & 27.0 & 26.9 & 26.3 & 26.1 & 25.9 & 25.6 & 25.3 \\
\hline Social benefits in kind & 7.3 & 7.4 & 8.2 & 8.2 & 8.3 & 8.3 & 8.0 & 8.0 & 7.9 & 7.9 \\
\hline Social transfers & 17.2 & 16.9 & 18.5 & 18.7 & 18.6 & 18.1 & 18.1 & 17.9 & 17.7 & 17.4 \\
\hline Of which: Pensions & 11.4 & 11.0 & 11.9 & 11.7 & 11.6 & 11.4 & 11.3 & 11.1 & 11.0 & 10.9 \\
\hline Child benefits & 1.4 & 1.4 & 1.5 & 1.6 & 1.6 & 1.6 & 1.6 & 1.5 & 1.5 & 1.5 \\
\hline Unemployment benefits & 2.0 & 1.9 & 2.5 & 2.8 & 2.9 & 2.7 & 2.7 & 2.6 & 2.5 & 2.5 \\
\hline Other expense & 3.3 & 3.0 & 3.3 & 3.3 & 3.3 & 3.3 & 3.3 & 3.3 & 3.3 & 3.4 \\
\hline Gross operating balance & 1.0 & 1.4 & -1.4 & -3.6 & -4.0 & -2.9 & -2.0 & -1.2 & -0.7 & -0.1 \\
\hline Net acquisition of nonfinancial assets & 0.8 & 1.4 & 1.9 & 2.1 & 1.1 & 1.1 & 1.1 & 1.1 & 1.1 & 1.1 \\
\hline Net lending/borrowing & 0.2 & 0.0 & -3.3 & -5.7 & -5.1 & -4.0 & -3.0 & -2.3 & -1.7 & -1.2 \\
\hline Primary balance & 3.0 & 2.8 & -0.6 & -3.1 & -2.5 & -0.9 & 0.0 & 0.6 & 1.0 & 1.5 \\
\hline \multicolumn{11}{|l|}{ Memorandum item: } \\
\hline Structural balance & 0.0 & -0.4 & -1.1 & -3.9 & -3.8 & -3.3 & -2.7 & -2.2 & -1.7 & -1.2 \\
\hline Change in structural balance & 1.4 & -0.4 & -0.7 & -2.8 & 0.1 & 0.5 & 0.5 & 0.5 & 0.5 & 0.5 \\
\hline Expense and net acquisition of nonfinancial assets & 43.7 & 43.7 & 47.7 & 48.1 & 46.7 & 46.4 & 45.8 & 45.3 & 45.0 & 44.6 \\
\hline Public gross debt (Maastricht definition) & 65.0 & 65.9 & 72.5 & 76.7 & 79.5 & 81.2 & 81.8 & 81.7 & 81.2 & 79.9 \\
\hline
\end{tabular}

Sources: Ministry of Finance; Bundesbank; Federal Statistical Office; and IMF staff estimates and projections. 


\section{INTERNATIONAL MONETARY FUND}

\section{GERMANY}

\section{Staff Report for the 2010 Article IV Consultation-Informational Annex}

Prepared by European Department

March 10, 2010

Contents

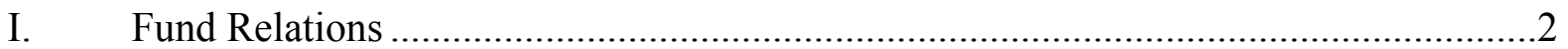

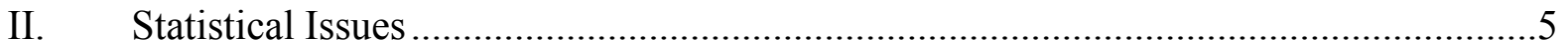




\section{ANNEX I. GERMANY: FUND RELATIONS}

(As of December 31, 2009)

Mission: January 28 to February 8, 2010 in Frankfurt, Bonn, and Berlin. The concluding statement of the mission is available at http://www.imf.org/external/np/ms/2010/020810.htm.

Staff team: Messrs. Kähkönen (Head), Berger, Schindler, Clausen (all EUR), Seelig (MCM), Tressel (RES), and Ms. Luedersen (LEG).

Country interlocutors: The Bundesbank President Weber, State Secretaries Storm (Labor), and Pfaffenbach (Economy), members of the German Council of Economic Experts, and senior representatives at the Chancellery, several ministries, the Bundesbank, and BaFin. Mr. von Stenglin, the Alternate Executive Director for Germany, also participated in the discussions. Meetings took place with employers, research institutes, and financial market participants.

Fund relations: The previous Article IV consultation discussions took place from November 12, 2008. The staff report was discussed by the Executive Board on January, 14 2009. The Executive Board's assessment and staff report are available at http://www.imf.org/external/pubs/cat/longres.cfm?sk=22627.0.

I. Membership Status: Joined August 14, 1952; Article VIII.

II. General Resources Account:

Quota

Fund holdings of currency

Reserve position in Fund

Lending to the Fund

III. SDR Department:

Net cumulative allocation

Holdings

\section{SDR Million}

$13,008.20$

$10,838.07$

$2,170.15$

338.10

SDR Million

$12,059.17$

$12,184.18$
Percent of Quota

100.00

83.32

16.68

Percent of Allocation

100.00

101.04

IV. Outstanding Purchases and Loans: None

V. Financial Arrangements: None 
VI. Projected Payments to Fund (SDR Million; based on existing use of resources and present holdings of SDRs):

\begin{tabular}{lccccc} 
& \multicolumn{5}{c}{ Forthcoming } \\
\cline { 2 - 6 } $\begin{array}{l}\text { Principal } \\
\text { Charges/Interest } \\
\text { Total }\end{array}$ & $\mathbf{2 0 1 0}$ & $\mathbf{2 0 1 1}$ & $\mathbf{2 0 1 2}$ & $\mathbf{2 0 1 3}$ & $\mathbf{2 0 1 4}$ \\
& 0.90 & $\underline{0.90}$ & $\underline{0.90}$ & $\underline{0.90}$ & $\underline{0.90}$ \\
\hline
\end{tabular}

\section{Exchange Rate Arrangement:}

Germany's currency is the euro, which floats freely and independently against other currencies.

Germany is an Article VIII member and maintains an exchange system free of restrictions on payments and transfers for current international transactions. It maintains measures adopted for security reasons, which have been notified to the Fund for approval in accordance with the procedures of Decision 144 and does so solely for the preservation of national or international security.

\section{Anti-Money Laundering/Combating the Financing of Terrorism (AML/CFT)}

An assessment under the international standard for AML/CFT was conducted by the Fund's Legal Department in May 2009. The detailed assessment report was adopted by the joint MENAFATF-FATF Plenary Meeting held in Abu Dhabi from February 17-19, 2010. The report concluded that, despite Germany introducing a number of measures in recent years to strengthen its AML/CFT regime, the AML/CFT framework is not fully in line with the standard. There are weaknesses in the legal framework and in sanctioning for noncompliance with AML/CFT requirements. The recommendations to address these include:

- $\quad$ amending the Criminal Code to: criminalize (i) ML in a way that covers all serious predicate offenses, and (ii) TF in a way fully consistent with international standards;

- $\quad$ amending the AML Act to: (i) improve preventive measures notably by imposing a reporting obligation based on suspicion rather than knowledge and that relates to the proceeds of criminal activity; and (ii) clearly establish that the FIU should carry out more of the core functions of an FIU as contemplated by the FATF standard;

- $\quad$ fully and effectively implementing the UN Security Council Resolutions (UNSCRs) on $\mathrm{TF}$;

- $\quad$ applying sanctioning powers more effectively for breaches of AML/CFT obligations;

- $\quad$ strengthening the effective implementation of AML/CFT obligations imposed on designated non-financial businesses and professions (DNFBPs); and 
- $\quad$ improving the collection of statistics and the provision of guidance and feedback to FIs.

Germany has made a clear commitment to further strengthen the national system for the prevention, detection and suppression of money laundering and terrorist financing.

\section{Staff Analytical Work on Germany, 2003-10}

\section{Growth and Competitiveness}

- Growth Linkages within Europe, IMF Country Report No. 08/81.

- Economic Impact of Shortages of Skilled Labor in Germany, IMF Country Report No. 08/81.

- What explains Germany’s Rebounding Export Market Share? CESifo Working Paper No. 1957.

- Long-run Growth in Germany. IMF Country Report No. 06/17.

- Does Excessive Regulation Impede Growth in Germany? IMF Country Report No. 06/17.

- The Performance of Germany's Non-Financial Corporate Sector - An International Perspective. IMF Country Report No. 06/17.

- Investment Trends in OECD Countries: Long-Term Developments and Future Prospects. IMF Country Report No. 04/340.

- Does PPP hold in the Long Run? Germany and Switzerland. IMF Country Report No. 04/340.

- Business Investment in the Current Cycle. IMF Country Report No. 03/342.

- After the Crisis: Lower Consumption Growth but Narrower Global Imbalances? IMF Working Paper No. 10/11.

\section{Inflation}

- Inflation Smoothing and the Modest Effect of VAT in Germany, IMF Working Paper No. 08/175.

- Simulating Inflation Forecasting in Real-Time: How Useful Is a Simple Phillips Curve in Germany, the UK, and the US? IMF Working Paper No. 10/52.

\section{Fiscal Policy and Entitlement Programs}

- Tax Reform and Debt Sustainability in Germany: An Assessment Using the Global Fiscal Model. IMF Country Report No. 06/436.

- Business Tax Reform. IMF Country Report No. 06/436.

- Why is Germany's Deficit so Large? IMF Country Report No. 06/17.

- A Preliminary Public Sector Balance Sheet for Germany, IMF Country Report No. 06/17.

- Germany: A Long-Run Fiscal Scenario Based on Current Policies, IMF Country Report No. 06/17. 
- Pensions and Growth. IMF Country Report No. 04/340.

- Federalism and the Political Economy of Adjustment. IMF Country Report No. $04 / 340$.

- Fiscal Policy in the Euro Area: Does Germany Play a Leadership Role? IMF Working Paper, forthcoming.

\section{Labor Markets}

- The Employment Effects of Labor and Product Markets Deregulation and their Implications for Structural Reform. CESifo Working Paper No 1709, May 2006.

- Employment, Unemployment, and Labor Supply in Germany. IMF Country Report No. 04/340.

- The Unbearable Stability of the German Wage Structure: Evidence and Interpretation. IMF Staff Papers, August 2004.

\section{The Financial System}

- Landesbanken: A Measure of the Costs for Taxpayers. IMF Country Report No. 06/436.

- The German Banking Sector: Credit Decline, Soundness and Efficiency. IMF Country Report No. 06/17.

- Germany's Three-Pillar Banking System. IMF Occasional Paper 233 (2004).

- Germany's Financial System: International Linkages and the Transmission of Financial Shocks. IMF Country Report No. 03/342.

- Credit Conditions in Germany Following the Global Sub-Prime Crises, IMF Working Paper, forthcoming.

\section{Corporate Governance}

- Germany's Corporate Governance Reforms: Has the System Become Flexible Enough?, IMF Working Paper No. 08/179. 


\section{ANNEX II. GERMANY: STATISTICAL ISSUES}

Data provision is adequate for surveillance. Germany has a full range of statistical publications and subscribes to the Fund's Special Data Dissemination Standard (SDDS). A ROSC Data Module report was published in January 2006. The authorities make substantial use of the Internet to facilitate on-line access to data and press information.

Germany adopted the European System of Integrated Economic Accounts 1995 (ESA95) in 1999. The 2005 ROSC Data Module mission found that the macroeconomic statistics generally follow internationally accepted standards and guidelines on concepts and definitions, scope, classification and sectorization, and basis for recording. However, the sources for estimating value added for a few categories of service industries could be improved. A direct source for quarterly changes in inventories, which is an important indicator of changes in GDP over the business cycle, is lacking. There is no systematic, proactive process to monitor the ongoing representativeness of the samples of local units and products between rebases of the producer price index.

Comprehensive data reporting systems support the accuracy and reliability of the government finance and balance of payments statistics. However, although explanatory documentation exists, differences between the general government data in the ESA95 classification and the general government cash data on an administrative basis is impairing fiscal analysis; Germany publishes - through Eurostat - general government revenue, expenditure, and balance on an accrual basis on a quarterly basis (ESA95) and submits annual data for publication in the Government Financial Statistics Yearbook, in GFSM 2001 format. Monthly data are only disseminated on a cash-basis.

Germany is participating in the Coordinated Compilation Exercise for financial soundness indicators (FSIs). In 2006, as part of this exercise, the German authorities compiled a comprehensive set of FSI data and metadata. 


\section{Germany: Table of Common Indicators Required for Surveillance}

(As of February 23, 2010)

\begin{tabular}{|c|c|c|c|c|c|c|c|}
\hline & \multirow{2}{*}{$\begin{array}{l}\text { Date of latest } \\
\text { observation }\end{array}$} & \multirow{2}{*}{$\begin{array}{l}\text { Date } \\
\text { received }\end{array}$} & \multirow{2}{*}{$\begin{array}{c}\text { Frequency } \\
\text { of } \\
\text { Data }^{7}\end{array}$} & \multirow{2}{*}{$\begin{array}{l}\text { Frequency } \\
\quad \text { of } \\
\text { Reporting }^{7}\end{array}$} & \multirow{2}{*}{$\begin{array}{l}\text { Frequency of } \\
\text { Publication }^{7}\end{array}$} & \multicolumn{2}{|c|}{ Memo Items } \\
\hline & & & & & & $\begin{array}{l}\text { Data Quality- } \\
\text { Methodological } \\
\text { soundness }^{8}\end{array}$ & $\begin{array}{l}\text { Data Quality- } \\
\text { Accuracy and } \\
\text { reliability }^{9}\end{array}$ \\
\hline Exchange Rates & $02 / 23 / 2010$ & $02 / 23 / 2010$ & $\mathrm{D}$ & $\mathrm{D}$ & $\mathrm{D}$ & & \\
\hline $\begin{array}{l}\text { International Reserve Assets and } \\
\text { Reserve Liabilities of the Monetary } \\
\text { Authorities }{ }^{1}\end{array}$ & January 09 & February 10 & $\mathrm{M}$ & $\mathrm{M}$ & $\mathrm{M}$ & & \\
\hline Reserve/Base Money & December 09 & January 10 & M & $\mathrm{M}$ & M & & \\
\hline Broad Money & December 09 & January 10 & M & $\mathrm{M}$ & $\mathrm{M}$ & & \\
\hline Central Bank Balance Sheet & December 09 & January 10 & $\mathrm{M}$ & M & M & & \\
\hline $\begin{array}{l}\text { Consolidated Balance Sheet of the } \\
\text { Banking System }\end{array}$ & December 09 & January 10 & $\mathrm{M}$ & $\mathrm{M}$ & $\mathrm{M}$ & & \\
\hline Interest Rates ${ }^{2}$ & January 10 & February 10 & $\mathrm{M}$ & $\mathrm{M}$ & $\mathrm{M}$ & & \\
\hline Consumer Price Index & January 10 & February 10 & $\mathrm{M}$ & $\mathrm{M}$ & $\mathrm{M}$ & & \\
\hline $\begin{array}{l}\text { Revenue, Expenditure, Balance } \\
\text { and Composition of Financing }{ }^{3}- \\
\text { General Government }^{4}\end{array}$ & Q3 09 & January 10 & $Q$ & $Q$ & $Q$ & 1010100 & \\
\hline $\begin{array}{l}\text { Revenue, Expenditure, Balance } \\
\text { and Composition of Financing }{ }^{3}- \\
\text { Central Government (cash basis) }\end{array}$ & January 10 & February 10 & $\mathrm{M}$ & $\mathrm{M}$ & $\mathrm{M}$ & $L U, L U, L U, U$ & $,, U, \cup, \cup$ \\
\hline $\begin{array}{l}\text { Stocks of General Government and } \\
\text { Government-Guaranteed Debt }{ }^{5}\end{array}$ & December 09 & January 10 & A & A & A & & \\
\hline External Current Account Balance & December 09 & January 10 & $\mathrm{M}$ & $\mathrm{M}$ & $\mathrm{M}$ & 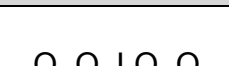 & $\cap \cap \Omega \cap \Omega$ \\
\hline Exports and Imports of Goods and & December 09 & February 10 & $\mathrm{M}$ & $\mathrm{M}$ & $\mathrm{M}$ & $U, U, L U, U$ & $U, U, U, \cup$ \\
\hline
\end{tabular}




\section{Germany: Table of Common Indicators Required for Surveillance}

(As of February 23, 2010)

\begin{tabular}{|l|c|c|c|c|c|c|}
\hline Services & & & & & \\
\hline GDP/GNP & Q4 09 & January 10 & Q & Q & Q & O, O, O, O \\
\hline Gross External Debt & September 09 & December 09 & Q O, O, O & Q & Q & \\
\hline International Investment Position $^{6}$ & September 09 & December 09 & Q & Q & Q & \\
\hline
\end{tabular}

${ }^{1}$ Includes reserve assets pledged or otherwise encumbered as well as net derivative positions.

${ }^{2}$ Both market-based and officially-determined, including discount rates, money market rates, rates on treasury bills, notes, and bonds.

${ }^{3}$ Foreign, domestic bank, and domestic nonbank financing.

${ }^{4}$ The general government consists of the central government (budgetary funds, extra budgetary funds, and social security funds) and state and local governments.

${ }^{5}$ Including currency and maturity composition

${ }^{6}$ Includes external gross financial asset and liability positions vis-a-vis nonresidents.

${ }^{7}$ Daily (D); weekly (W); monthly (M); quarterly (Q); annually (A); irregular (I); and not available (NA)

${ }^{8}$ Reflects the assessment provided in the data ROSC (published on January 18, 2006, and based on the findings of the mission that took place during July $5-20,2005)$ for the dataset corresponding to the variable in each row. The assessment indicates whether international standards concerning methodological soundness, namely, (i) concepts and definitions, (ii) scope, (iii) classification/sectorization, and (iv) basis for recording are fully observed (O); largely observed (LO); largely not observed (LNO); not observed (NO); and not available (NA).

${ }^{9}$ Same as footnote 8, except referring to international standards concerning accuracy and reliability, namely, (i) source data, (ii) assessment of source data, (iii) statistical techniques, (iv) assessment and validation of intermediate data and statistical outputs, and (v) revision studies. 


\section{INTERNATIONAL MONETARY FUND}

Public Information Notice

EXTERNAL

RELATIONS

DEPARTMENT

Public Information Notice (PIN) No. 10/44

FOR IMMEDIATE RELEASE

March 30, 2010

International Monetary Fund

$70019^{\text {th }}$ Street, NW

Washington, D. C. 20431 USA

\section{IMF Executive Board Concludes 2010 Article IV Consultation with Germany}

On March 29, 2010, the Executive Board of the International Monetary Fund (IMF) concluded the Article IV consultation with Germany. ${ }^{1}$

\section{Background}

Germany was hit exceptionally hard by the global crisis, but strong policies helped to avoid an even deeper recession. After a sharp fall in real GDP in the first half of 2009, broad-based policy support and an uptick in global demand lifted the economy in the second half, keeping the GDP contraction to 4.9 percent for 2009. The recovery is expected to continue at a moderate pace, with real GDP growth projected to reach 1.2 percent in 2010 and 1.7 percent in 2011. There are substantial downside risks, however, reflecting remaining banking weaknesses and the possibility of weaker-than-expected global trade.

The authorities used the available fiscal space to implement countercyclical policy measures. Direct spending, tax cuts, the cash-for-clunkers scheme, and employment subsidies boosted demand in 2009, but also increased the general government deficit to 31/4 percent of GDP from a broadly balanced budget the year before. In 2010, implementation of remaining stimulus measures and additional tax cuts and transfers are projected to bring the deficit to $51 / 2$ percent of GDP, nearly twice the limit set by the European Union's Stability and Growth Pact (SGP). The deficit is large also by the standards of the new constitutional rule to secure long-term fiscal

\footnotetext{
${ }^{1}$ Under Article IV of the IMF's Articles of Agreement, the IMF holds bilateral discussions with members, usually every year. A staff team visits the country, collects economic and financial information, and discusses with officials the country's economic developments and policies. On return to headquarters, the staff prepares a report, which forms the basis for discussion by the Executive Board. At the conclusion of the discussion, the Managing Director, as Chairman of the Board, summarizes the views of Executive Directors, and this summary is transmitted to the country's authorities. An explanation of any qualifiers used in summings up can be found here: http://www.imf.org/external/np/sec/misc/qualifiers.htm.
} 
sustainability, which requires the structural federal fiscal balance to be near zero starting in 2016.

Financial sector measures helped stabilize financial markets and mitigated systemic risk, but vulnerabilities remain. Crisis measures included recapitalizations and credit guarantees through the Sonderfonds Finanzmarktstabilisierung (SoFFin) and public commitments to protect household bank deposits. While the overall health of the financial sector has improved since the crisis, several sources of vulnerabilities linger, including the credit risks from a still fragile recovery and sizeable remaining write-downs, and banks' exposure to emerging and Southern European markets. The structurally unprofitable Landesbanken continue to pose systemic risks.

Unemployment has increased slowly so far-owing to past labor market reforms and crisis policies. The Hartz IV reforms have strengthened employment going into the crisis; and the improved possibility to adjust work time under collective wage agreements and the short-time work scheme helped firms to avoid dismissals. However, with a diminished growth outlook, firms will eventually adjust their work force, especially in the hard-hit manufacturing sector. This could severely test the overall flexibility of the German labor market, which is still characterized by high employment protection. Moreover, existing obstacles to services sector development and product market competition increase the danger of a drawn-out structural adjustment to the post-crisis world.

\section{Executive Board Assessment}

Executive Directors noted that timely and appropriate policy response and a recovery of exports helped lift the economy from the recession. Economic recovery is likely to be moderate and fragile, reflecting its reliance on export demand and risks from continuing financial sector problems.

Against this background, Directors noted that the authorities face the challenge of sustaining recovery while preparing to exit, as part of an international coordinated strategy, from the extraordinary measures introduced during the crisis. Directors agreed that over time fiscal policy will have to transition from support to credible consolidation. In the financial sector, repair and restructuring of balance sheets must continue, but it is now also necessary to make more permanent improvements to the framework of institutions designed to safeguard financial stability and manage financial crisis in concert with ongoing EU initiatives. Special labor market policies introduced to maintain employment during the crisis will need to be phased out and structural reforms undertaken to raise longer-term growth and domestic demand. A few Directors noted that designing structural policies to raise domestic demand will not be easy.

Directors welcomed the authorities' fiscal strategy that combines short-run support for the economy with a firm commitment to fiscal consolidation in the medium term. They supported the continued fiscal stimulus in the 2010 budget in light of the still fragile recovery. Directors saw a need to start fiscal consolidation once the recovery becomes self sustaining, which is projected for 2011. Turning to the medium term, they agreed that meeting the national and European 
fiscal goals would help Germany prepare for the challenges of its aging population and anchor the fiscal policy consolidation in the euro area. Directors stressed that a credible consolidation plan with strong measures, focused on expenditures, will be needed to reach the medium-term targets. In this context, any tax cut in 2011 should be accompanied by compensating budgetary measures. They generally welcomed the authorities' decision to establish a new fiscal constitutional rule that imposes limits on the government's structural deficit.

Directors called for continued financial sector restructuring and welcomed plans to overhaul the financial stability framework. While banking sector health has improved, vulnerabilities persist. They considered that strengthening capital buffers should be a priority for most banks. Directors noted that the larger public banks (the Landesbanken) will require additional restructuring and major consolidation to enhance financial stability and reduce fiscal support for this sector. They also welcomed the authorities' intention to make the Bundesbank the sole prudential bank supervisor, stressing the need to ensure accountability and operational independence. Directors commended the efforts to install a strong and effective regime for bank resolution building on the temporary measures introduced during the crisis. At the same time, they pointed out the advantages of strengthening and unifying Germany's fragmented deposit protection scheme in light of evolving EU initiatives. Directors noted the authorities' commitment to undertake a Financial Sector Assessment Program (FSAP) update.

Directors welcomed the authorities' intention to adjust labor market policies to the pace of the recovery and called for additional structural reforms to help Germany's adjustment to the postcrisis world. Simultaneous measures to increase labor market flexibility and reduce obstacles to product and service market development would enhance efficiency and foster domestic demand. Directors noted that strengthening domestic sources of growth will help cushion the German economy against external shocks as well as benefit the euro area countries and the global economy by reducing trade and payments imbalances.

Public Information Notices (PINs) form part of the IMF's efforts to promote transparency of the IMF's views and analysis of economic developments and policies. With the consent of the country (or countries) concerned, PINs are issued after Executive Board discussions of Article IV consultations with member countries, of its surveillance of developments at the regional level, of post-program monitoring, and of ex post assessments of member countries with longer-term program engagements. PINs are also issued after Executive Board discussions of general policy matters, unless otherwise decided by the Executive Board in a particular case. The staff report (use the free Adobe Acrobat Reader to view this pdf file) for the 2010 Article IV Consultation with Germany is also available. 
Germany: Selected Economic Indicators

\begin{tabular}{|c|c|c|c|c|c|c|c|}
\hline & 2005 & 2006 & 2007 & 2008 & 2009 & $20101 /$ & $20111 /$ \\
\hline \multicolumn{8}{|l|}{ Real economy (change in percent) } \\
\hline Real GDP & 0.7 & 3.2 & 2.5 & 1.2 & -4.9 & 1.2 & 1.7 \\
\hline Total domestic demand & 0.0 & 2.2 & 1.0 & 1.7 & -1.6 & -0.8 & 1.3 \\
\hline CPI (average) & 1.9 & 1.8 & 2.3 & 2.8 & 0.2 & 0.9 & 1.0 \\
\hline Standardized unemployment rate (in percent) & 9.1 & 8.1 & 8.3 & 7.2 & 7.4 & 8.6 & 9.3 \\
\hline Employment growth & -0.1 & 0.7 & 1.7 & 1.4 & -0.2 & -1.6 & -0.7 \\
\hline Gross national saving (percent of GDP) & 22.5 & 24.3 & 26.3 & 25.4 & 22.8 & 23.7 & 23.9 \\
\hline Gross domestic investment (percent of GDP) & 17.4 & 18.2 & 18.8 & 19.0 & 18.0 & 18.3 & 18.4 \\
\hline \multicolumn{8}{|l|}{ Public finance (percent of GDP) } \\
\hline General government balance & -3.3 & -1.6 & 0.2 & 0.0 & -3.3 & -5.7 & -5.1 \\
\hline General government structural balance & -2.2 & -1.4 & 0.0 & -0.4 & -1.1 & -3.9 & -3.8 \\
\hline General government debt & 68.0 & 67.6 & 65.0 & 65.9 & 72.5 & 76.7 & 79.5 \\
\hline \multicolumn{8}{|l|}{ Money and credit (end of year, percent change) 2/ } \\
\hline Credit to private sector & 2.1 & 3.5 & 3.2 & 6.5 & -0.7 & -1.5 & $\ldots$ \\
\hline M3 & 5.2 & 4.9 & 10.7 & 9.6 & -1.4 & -2.5 & $\ldots$ \\
\hline \multicolumn{8}{|l|}{ Interest rates (percent) } \\
\hline Money market rate $3 /$ & 2.1 & 3.7 & 4.8 & 3.4 & 0.7 & 0.6 & $\ldots$ \\
\hline Government bond yield 3/ & 3.6 & 3.8 & 4.3 & 3.2 & 3.2 & 3.2 & $\ldots$ \\
\hline \multicolumn{8}{|l|}{ Balance of payments (percent of GDP) } \\
\hline Current account balance & 5.1 & 6.1 & 7.5 & 6.4 & 4.8 & 5.4 & 5.5 \\
\hline Trade balance & 6.4 & 6.3 & 7.7 & 7.1 & 5.2 & 6.9 & 7.5 \\
\hline Exports & 35.3 & 38.9 & 40.5 & 39.4 & 33.4 & 34.6 & 34.6 \\
\hline Volume (annual percent change) & 7.6 & 12.7 & 7.5 & 3.0 & -16.4 & 5.6 & 2.2 \\
\hline Imports & 28.8 & 32.6 & 32.8 & 32.3 & 28.3 & 27.7 & 27.1 \\
\hline Volume (annual percent change) & 7.1 & 13.7 & 4.8 & 5.0 & -9.9 & 1.3 & 1.3 \\
\hline Net oil imports (billions of US\$) & 61.4 & 78.8 & 79.5 & 117.0 & 70.8 & 89.7 & 94.5 \\
\hline FDI balance & -1.0 & -2.4 & -3.7 & -3.7 & -2.7 & -2.5 & -2.6 \\
\hline Official reserves minus gold (billions of US\$) 4/ & 45.1 & 41.7 & 44.3 & 43.1 & 60.4 & $\ldots$ & $\ldots$ \\
\hline \multicolumn{8}{|l|}{ Exchange rate } \\
\hline Exchange rate regime & \multicolumn{7}{|c|}{ Participant in euro zone } \\
\hline Present rate (December 31, 2009) & & & $\mathrm{Eu}$ & 0.7 per & & & \\
\hline Nominal effective rate $(2000=100) 3 /$ & 110.3 & 112.3 & 115.9 & 116.0 & 117.0 & 115.8 & $\ldots$ \\
\hline Real effective rate $(2000=100) 5 /$ & 103.2 & 97.0 & 97.3 & 92.6 & 91.7 & 90.7 & $\ldots$ \\
\hline
\end{tabular}

Sources: Deutsche Bundesbank; Eurostat; IFS; WEO; and IMF staff estimates and projections.

$1 /$ Staff estimates and projections, if not otherwise indicated.

2/ Reflects Germany's contribution to M3 of the euro area. Data for 2010 refer to January.

3/ Data for 2010 refer to February.

4/ Data for 2009 refer to December.

5/ Based on relative normalized unit labor cost in manufacturing. Data for 2010 refer to January. 


\section{Statement by Klaus Stein, Executive Director for Germany \\ March 29, 2010}

I would like to thank the staff for a well written and balanced report and to express my authorities' appreciation for focused and open discussions during the consultation.

My authorities broadly share the staff's assessment of the current economic situation and the prospects of the German economy. Because of the strong links to the world economy, Germany was hit particularly hard by the global financial and economic crises. Germany's gross domestic product fell by five percent in real terms in 2009, the sharpest drop since the founding of the Federal Republic. Both strong domestic policy support and recovering global demand have positively affected the German economy; a moderate recovery is underway. In January, the federal government revised its projection of real gross domestic product growth from 1.2 percent to 1.4 percent in 2010 , slightly higher than the staff's projection.

With the changing economic situation, policy demands are changing, too. To ensure that crisis-related state interventions and support measures do not throttle individual initiative and forces for innovation, the German authorities will focus on a consistent exit strategy. The right timing and design of exit strategies in fiscal policy, monetary policy and the financial sector is important for the sustainability of the recovery and will help build positive expectations in the markets. Most government measures to stabilize the financial system and to support companies and consumers will expire at the end of 2010. My authorities are also well aware of the importance of international cooperation and advocate an internationally coordinated strategy for an orderly exiting.

\section{Economic situation}

The comprehensive measures undertaken to support the financial system and the economy have made a marked contribution towards stabilizing the economic situation and securing the long-term perspectives for growth in Germany. In 2009 the stimulus measures (inter alia tax relief, car-scrapping program, stabilization of the labor market) were implemented at the right time, as exports declined very sharply. While both private consumption ( +0.2 percent in real terms) and public consumption $(+3.0$ percent $)$ have been stabilizing factors in 2009, in 2010 the stimulus focuses on investment which will lead to an increase in total domestic demand by 0.6 percent. Moreover, net real wages are expected to rise. My authorities are very confident that there will be no massive increase in unemployment as expected in the wake of the severe economic crisis.

Over the last years, the German labor market has become more dynamic, flexible, and adaptive, and has proven to be remarkably robust during the crisis. Increased firm-level flexibility to smooth working hours over the cycle, a stronger underlying employment trend, 
and the very effective government program subsidizing short-time work (Kurzarbeit) played an important role in containing job losses. However, as unit labor costs have increased substantially, the scope for keeping the high level of short-time work is limited. The aim of a currently ongoing debate is to find the right balance between the benefit of short-time work as a means to stabilize employment and income and the potential negative effects of hampering necessary structural labor market adjustments.

My authorities agree with staff that the financial and economic crisis will have a negative impact on potential output growth in the medium term. For the time being, potential output may only increase at a moderate pace and the current under-utilization of industrial capacity will probably ease only gradually over time. However, looking ahead, the recuperation process will be supported by structural reforms. Alongside the immediate measures that have been taken to boost the economy, implementing structural reforms in order to expand opportunities for longer-term growth and to strengthen domestic sources of growth is a priority for my authorities.

\section{Fiscal policy}

Germany's fiscal policy strategy is fully in line with IMF recommendations. Fiscal support will be maintained in 2010 as the German economy has not reached a self-supporting and stable growth path yet. The government will implement the fiscal stimulus measures as planned and as announced internationally. Moreover, my authorities have adopted further measures which amount to an additional stimulus of around $€ 6$ billion or $1 / 4$ percent of GDP in 2010 with the "Economic Growth Acceleration Act" (Wachstumsbeschleunigungsgesetz) which entered into force January $1^{\text {st }}, 2010$. Thereby, Germany set additional incentives for investments and lowered the fiscal burden of families.

Despite the crisis and the necessary fiscal stimulus measures, the overall deficit could be contained to 3.3 percent of GDP in 2009; only marginally above the requirement of the European Stability and Growth Pact. For 2010, my authorities project an overall deficit of around 5.5 percent of GDP. The cost of the automatic stabilizers, the discretionary fiscal stimulus measures, measures taken to stabilize the financial system, and by no small means the decline in GDP led to a substantial increase in the ratio of general government debt to GDP to 73 percent in 2009. The debt to GDP ratio is expected to increase further to 77 percent in 2010 and to reach around 82 percent by 2013.

From 2011 onwards, the focus will be on fiscal consolidation, as called for under the European Stability and Growth Pact as well as the new national constitutional rule (Schuldenbremse) to limit the government deficit. My authorities continue to pursue their medium-term goal of a close-to-balance government budget in structural terms. 
Given my authorities' ambitious approach with regard to expenditure cuts, sound public finances can most likely be reached without further revenue measures.

Nevertheless, should the next tax forecast show a need for revenue measures, tax broadening would be preferable to higher tax rates. My authorities do not intend to increase VAT rates. Furthermore, they are of the view that the relatively low unemployment contribution rate has considerably contributed to mitigating the effects of the current economic crisis on the German labor market. Therefore, no further increases in the contribution rate are under consideration at present, apart from the raise of the contribution rate from 2.8 percent to 3 percent already scheduled for January $1^{\text {st }}, 2011$.

Independent of the consolidation efforts, my authorities see a strong need for growth enhancing tax policies contributing to an increasing motivation of consumers, enterprises, and investors. My authorities plan to implement a simpler tax system with lower tax rates and measures to reduce bureaucracy. Providing relief, particularly to lower and middle income groups, will support consumption and create incentives to work. The new tax structure is supposed to enter into force on January $1^{\text {st }}, 2011$, taking into account both economic developments including their effects on the perspectives for the public budgets, and structural savings. This is to create the necessary leeway in line with the budget rules set out under European and constitutional legislation.

\section{Spillovers}

My authorities share the staff's view that fiscal policy in Germany has a role model function for other $\mathbf{E} \mathbf{U}$ countries. Therefore, as stated earlier, my authorities are determined to adhere to the requirements of the Stability and Growth Pact and to the recommendations of the ECOFIN Council to correct the excessive deficit in order to set an example for much needed fiscal consolidation in Europe.

Overall, Germany played a significant role in stabilizing the world economy in 2009. While German exports plummeted in 2009, imports dropped less and contributed to narrowing Germany's current account surplus. According to preliminary calculations, in 2009 the German current account surplus decreased by nearly $€ 48$ billion or about 2 percent of GDP compared to 2008. Furthermore, it is noteworthy that the German current account surplus is not the result of policy measures explicitly aimed at promoting export performance but rather the result of a multitude of private business decisions. Germany's strong export orientation stems from the openness of its economy, its long-standing manufacturing traditions and its competitiveness in global markets.

Nevertheless, my authorities recognize that higher domestic demand would not only contribute to reduce the current account surplus but would be beneficial for Germany. However, means to promote domestic demand are rather limited. Wages are not a 
macroeconomic policy tool in Germany, and income tax cuts beyond the proposed measures would have a detrimental effect on fiscal consolidation. Having said that, my authorities support the conclusions of the Eurogroup of March $15^{\text {th }}, 2010$, regarding intra Euro area competitiveness and macroeconomic imbalances. As called for in the conclusions, my authorities stand ready to identify and implement structural reforms that help strengthening domestic demand.

\section{Financial Sector}

Stability in the financial sector has significantly improved during the last year and systemic risks continue to subside as economic fundamentals recover. Measures as the establishment of the Sonderfonds Finanzmarktstabilisierung (SoFFin) providing guarantees and funding for recapitalization of financial institutions have contributed substantially to the stabilization of the financial sector. However, there are still pressing challenges from the crisis and reasons to remain cautious. Financial institutions faced and are still facing massive write-downs. For securitizations, however, the vast majority of potential losses has already been accounted for. With regard to potential adverse repercussion due to continuing stress in the real economy and the financial sector, Germany benefits from comparatively moderate indebtedness of both corporations and households as well as from price stability in the real estate sector.

For the time being a credit crunch cannot be observed. However, with increasing numbers of insolvencies in the real economy and rising unemployment rates, further pressure on banks' balance sheets could lead to potentially negative consequences for lending. Thus, since March 2010, businesses facing lending problems are able to turn to a governmentappointed credit mediator who will take action to ensure that creditworthy companies particularly small and medium-sized firms - are able to obtain loans. Furthermore, the credit guarantee program of the "Business Fund Germany" (Wirtschaftsfonds Deutschland) established in March 2009 is an option for companies to secure access to credit.

The ongoing restructuring process of the Landesbanken is a necessary step and contributes to stability in this sector. After several Landesbanken received financial aid from states (Länder) and the SoFFin during the current financial crisis, they will have to downsize and/or change their business model as required by state aid rules of the European Union aiming at preventing distortions of competition due to government interventions. Länder governments are committed to this reform process.

Regulatory and supervisory reforms of the financial sector remain a key priority for my authorities. Ongoing work in that area is done in cooperation with regional and international partners with the target to emerge from the current crisis with an enhanced and strengthened 
framework ensuring that all financial institutions, instruments and markets are subject to adequate regulation and oversight.

The reform of financial supervision envisages a consolidated banking supervision in the Bundesbank. My authorities agree with staff that, as under the current regime, the supervisory body has to be both accountable and operationally independent. Detailed reform proposals taking into account existing synergies of an integrated financial supervision and the independency of the Bundesbank will be presented in the summer. The new supervision structure is scheduled to become effective in spring 2011.

\section{My authorities intend to develop a legal framework for an effective bank resolution} regime which allows for timely action to prevent systemic contagion. The key objectives of this resolution regime will be to enable early interventions as well as a managed resolution and an orderly wind-down of systemically-important banks. Such a framework can impose market discipline and, by providing a mechanism to ensure appropriate financial contribution of the private sector, protect public funds. This new national framework corresponds with conclusions on the G20 level and complements recent initiatives by the European Commission, i.e., the advised proposal for a European Framework for Cross-Border Crisis Management in the Banking Sector.

The deposit insurance system is a pillar of financial stability in Germany and has proven its quality during the financial crisis. Despite several ailing banks, none of the depositors has lost any of its protected deposits during the financial crisis, neither in the sector of the private banks nor in the sectors of Sparkassen and mutual banks (Kreditgenossenschaften). In the latter sectors, where the system does not only protect deposits but also prevents insolvency of banks, no bank has become insolvent in the last five decades. Since the establishment of the private banking sector, no depositor suffered any loss of protected deposits in the case of an insolvency of a private bank that was a member of the German deposit insurance system. In the current crisis, the SoFFin supported only the voluntary scheme of the association of private banks, not any of the mandatory ones. Nevertheless, Germany is developing its system and is actively taking part in the current discussions at EU level to make depositor protection even more efficient. 